\title{
A review of the Cis-Andean species of Hemibrycon Günther (Teleostei: Characiformes: Characidae: Stevardiinae), with description of two new species
}

\author{
Vinicius A. Bertaco and Luiz R. Malabarba
}

The species of Hemibrycon occurring in the east of the Andean Cordilleras are reviewed based on their type series and additional specimens. Nine species are redescribed: $H$. beni from río Beni basin, Bolivia; $H$. helleri from the upper rio Ucayali, Peru; H. huambonicus from the ríos Huallaga and Marañon basins, Peru; H. jeslkii from the upper portions of ríos Marañon, Ucayali and Madeira basins, Bolivia, Brazil, and Peru; H. metae from río Orinoco basin, Colombia and Venezuela, and Caribbean coastal basins of Venezuela; H. polyodon (type species) from río Pastaza basin, Ecuador; H. surinamensis from coastal basins of French Guiana and Suriname, and from lower rios Tapajós, Tocantins and Xingu basins, Brazil; $H$. taeniurus from river basins from Trinidad Island, Trinidad and Tobago, and $H$. tridens from upper río Ucayali basin, Peru. Two new species are described: H. inambari from the upper río Madre de Dios basin, Peru and H. mikrostiktos from río Ucayali basin, Peru. These species are distinguished among themselves mainly by the color pattern, and meristic characters. The distribution area of the genus is enlarged reaching the lower Tapajós, Tocantins and Xingu river basins, Brazil, with the first record of the occurrence of $H$. surinamensis in this country. A new description and diagnosis is provided for the type species of the genus, regardless its recent redescription. The type series of $H$. helleri that was previously considered dubious is found and described. Hemibrycon coxeyi and H. pautensis are considered junior synonyms of H. polyodon. Tetragonopterus (Hemibrycon) trinitatis, previously considered species inquirenda in Characidae, and Hemibrycon guppyi are junior synonyms of $H$. taeniurus. Hemibrycon orcesi is transferred to Boehlkea. A taxonomic key for the species of the genus to the east of the Andean Cordilleras is presented.

As espécies de Hemibrycon que ocorrem a leste das Cordilheiras dos Andes são revisadas com base na análise do material tipo e exemplares adicionais. Nove espécies são redescritas: $H$. beni da bacia do río Beni, Bolívia; $H$. helleri do alto río Ucayali, Peru; H. huambonicus para as bacias dos ríos Huallaga e Marañon, Peru; H. jeslkii para as porções superiores das bacias dos rios Marañon, Ucayali e Madeira, Bolívia, Brasil e Peru; H. metae para a bacia do río Orinoco, Colômbia e Venezuela, e bacias costeiras do Caribe na Venezuela; H. polyodon (espécie-tipo) para a bacia do río Pastaza, Equador; H. surinamensis para as bacia costeiras da Guiana Francesa e Suriname, e porção inferior das bacias dos rios Tapajós, Tocantins e Xingu, Brasil; $H$. taeniurus para os rios da ilha de Trinidad, Trinidad and Tobago; H. tridens para a bacia do alto río Ucayali, Peru. Duas espécies novas são descritas: H. inambari para a bacia do alto río Madre de Dios, Peru e H. mikrostiktos para a bacia do río Ucayali, Peru. Estas espécies distinguem-se principalmente pelo padrão de colorido e caracteres merísticos. A área de distribuição do gênero é ampliada para as porções inferiores das bacias do Tapajós, Tocantins e Xingu, Brasil, com o primeiro registro de $H$. surinamensis para este país. Uma nova diagnose e descrição são fornecidas para a espécie-tipo do gênero, apesar de ter sido recentemente redescrita. A série-tipo de $H$. helleri previamente considerada questionável é encontrada e descrita. Hemibrycon coxeyi e H. pautensis são considerados sinônimos juniores de H. polyodon. Tetragonopterus (Hemibrycon) trinitatis, anteriormente considerada como species inquirenda em Characidae, e Hemibrycon guppyi são sinônimos juniores de $H$. taeniurus. Hemibrycon orcesi é transferida para Boehlkea. É apresentada uma chave taxonômica para as espécies do gênero a leste das Cordilheiras dos Andes.

Key words: Neotropical, Taxonomy, Boehlkea, Bryconamericus, Freshwater fish.

Universidade Federal do Rio Grande do Sul, Instituto de Biociências, Departamento de Zoologia, Laboratório de Ictiologia. Av. Bento Gonçalves, 9500, 91501-970 Porto Alegre, RS, Brazil. vbertaco@gmail.com, malabarb@ufrgs.br 


\section{Introduction}

Hemibrycon Günther, 1864 is a Neotropical genus of characid fishes comprising twenty eight valid species, sixteen Trans-Andean species distributed in the coastal drainages of the Pacific slope of Panama and in between Caribean slopes of Panama and Venezuela (including the ríos Atrato and Magdalena and Lago Maracaibo basins), and twelve Cis-Andean species distributed in the range between Caribbean coastal basins of Venezuela to lower rio Tocantins basin (including the río Orinoco basin, Trinidad and Tobago island, and río Amazon basin in Bolivia, Brazil, Ecuador, and Peru; Bertaco et al., 2007; Eschmeyer, 2010; this paper).

The genus Hemibrycon was proposed by Günther (1864), as a subgenus of Tetragonopterus Cuvier, differing by "cleft of the mouth of moderate width, and the entire edge of the maxillary denticulated". Tetragonopterus polyodon Günther was designed as type species. Hemibrycon was extensively revised by Eigenmann (1927), whose accounts still constitute the single complete review of the genus. Publications on Hemibrycon subsequent to Eigenmann's revision usually involve only descriptions of new species occurring in restricted geographic areas of South America (e.g., Bertaco et al., 2007; Román-Valencia $\&$ Arcila-Mesa, 2009). The genus still lacks a phylogenetic diagnosis, and is currently delimited based on Eigenmann (1917, 1927), as caudal fin naked, premaxillary with two series of teeth, inner series with four teeth, infraorbital 2 in contact with the lower limb of the preopercle, adipose fin present, anal fin moderate or long, gill rakers simple, teeth along the greater part or along the entire edge of the maxillary. However, none of the characters used are unique to the genus and most of them are plesiomorphic within Characidae or treated as putative synapomorphies of more inclusive clades containing Hemibrycon (Malabarba \& Weitzman, 2003).

Malabarba \& Weitzman (2003) hypothesized Hemibrycon as belonging to a large monophyletic clade inside Characidae, Clade A, based on the putative derived presence of four teeth in the inner series of the premaxilla and reduced number of dorsal-fin rays (ii,8), also including the subfamily Glandulocaudinae (Glandulocaudinae and Stevardiinae sensu Weitzman et al., 2005) and the genera Attonitus Vari \& Ortega, Boehlkea Géry, Bryconacidnus Myers, Bryconamericus Eigenmann, Caiapobrycon Malabarba \& Vari, Ceratobranchia Eigenmann, Creagrutus Günther, Cyanocharax Malabarba \& Weitzman, Hypobrycon Malabarba \& Malabarba, Knodus Eigenmann, Microgenys Eigenmann, Monotocheirodon Eigenmann \& Pearson, Odontostoechus Gomes, Othonocheirodus Myers, Piabarchus Myers, Piabina Reinhardt, Rhinobrycon Myers, and Rhinopetitia Géry. The group was latter expanded with the addition of Bryconadenus by Weitzman et al. (2005), Phallobrycon by Menezes et al. (2009), and Aulixidens and Nantis by Mirande $(2009,2010)$.
Recent phylogenetic studies among characid fishes, involving the analysis of nuclear and mitochondrial genes (Calcagnotto et al., 2005; Javonillo et al., 2010), or osteology and external morphology (Mirande, 2009, 2010) have corroborated the hypothesis of the monophyly of Clade A including Hemibrycon. Mirande $(2009,2010)$ further redefined Clade A and elevated the rank of Stevardiinae to correspond to Clade A, instead of a section of it. Since no further decision was presented by Mirande $(2009,2010)$ regarding the tribes Corynopomini, Diapomini, Glandulocaudini, Stevardiini, and Xenurobryconini, or to which tribes should be referred the remaining Clade A genera, and due to the lack of evidence of non-monophyly of the tribes previously proposed, we will keep their use as internal monophyletic clades in Stevardiinae (sensu Mirande).

Herein we review the Hemibrycon species occurring in the east of the Andean Cordilleras, redescribe nine species based in the analysis of their type series and additional specimens, and also describe two new species, one from río Madre de Dios basin and other from the upper río Ucayali basin, both in Peru.

\section{Material and Methods}

Counts were taken as described by Fink \& Weitzman (1974), with the exception of number of scale rows below lateral line which were counted from the scale row ventral to lateral line to the scale row nearest the first pelvic-fin ray. Vertebral counts, supraneurals, gill rakers, teeth, and procurrent caudal-fin-ray counts were taken from cleared and stained specimens (c\&s) prepared according to the method of Taylor \& van Dyke (1985). The gill raker at the junction of the ceratobranchial and the epibranquial is included in the counting of gill rakers of lower limb. Maxillary tooth counts were also taken in specimens included in the tables. Vertebral counts were also taken in radiographs specimens ( $\mathrm{x}$-ray) and include the four vertebrae integrated in the Weberian apparatus and the terminal centrum, which was counted as one vertebra. Scanning electron micrographs (SEM) of teeth and jaws were taken from cleared and stained dissected specimens.

Measurements were taken point-to-point with an electronic caliper on the left side of specimens when possible. All measurements other than SL are expressed as a percentage of SL except subunits of the head, which are recorded as a percentage of head length. Box plots of the anal-fin rays and lateral line counts were constructed with SigmaPlot 2.0 for Windows; basic descriptive statistics for meristic data follow Weitzman \& Malabarba (1999). Morphometric data for the type series of each species and non-type specimens are presented separately in tables. Although this review deals only with Cis-Andean species, the diagnoses are compared to all species of the genus.

Institutional abbreviations follow Reis et al. (2003), with the addition of the Instituto de Investigaciones Biológicas Alexander von Humboldt - Peces, Villa de Leyva, Boyacá 
(IAvH-P), and Departamaneto de Zoologia, Universidade Federal do Rio Grande do Sul, Porto Alegre (UFRGS). List of the examined specimens of each species includes in this order: catalog number; total number of specimens in that lot, followed by the number of c\&s and/or X-ray specimens in parentheses when available, standard length range, sex for main types, collecting locality, coordinates, and date. Collectors are given for type series of each species when disponible. List of comparative material includes in this order: catalog number; total number of specimens in that lot (and number of c\&s specimens in parentheses when available), and collecting locality. The synonymy provided for each species contains only papers that include taxonomic changes or and/or illustrate characters.

Sex of adult specimens of Hemibrycon was recognized by visual examination of their gonads and/or by the presence or absence of the bony hooks in fin rays. For histological analyses, the gonads were obtained from specimens deposited in institutional fish collections, probably fixed in $10 \%$ formalin and stored in $70 \%$ ethanol prior to sectioning. Ovaries and testes were removed from one side, dehydrated in $99 \%$ ethanol, and infiltrated and embedded in glycol methacrylate. Saggital sections were made at $0.5 \mu \mathrm{m}$ with microtome, mounted on glass slides, and stained either with toluidine blue and alizarin-red. For scanning electron microscopy (SEM), the pieces of mature testes of some Hemibrycon species were dehydrated in ethanol series, dried in a critical point dryer, and scattered upon a carbon tape of the stub and viewed with a scanning electron microscope.

Gill gland (Burns \& Weitzman, 1996) observations in males and females were made through light microscopy under stereomicroscope. When verified the presence of a gill gland, the first gill arch from one side was removed, dehydrated in ethanol series and critical point dryer. The gill arch was fixed upon the stub with a carbon tape, coated with gold in a sputtercoater, and viewed with a scanning electron microscope (SEM).

\section{Results}

\section{Hemibrycon beni Pearson, 1924 Fig. 1}

Hemibrycon beni Pearson, 1924: 42-43 (original description; type material; type locality: Espia and río Colorado, lower Bopi, Bolivia), 62-63 (pl. 2, fig. 6, cotype).

Diagnosis. Hemibrycon beni is readily distinguished from most congeners, except $H$. mikrostiktos, H. paez, H. tridens, and $H$. virolinica, by the number of branched anal-fin rays (15-19 vs. 20-34, Fig. 2). Hemibrycon beni differs from these species by the number of lateral line scales (44-53 vs. 40-42, 39-42, 39, and 40-44, respectively). Furthermore, H. beni differs from $H$. virolinica by the number of predorsal scales (17-20 vs. 10-15). The branched anal-fin ray counts of $H$. beni overlapping somewhat the $H$. helleri counts (15-19 vs. 19-23), but they can be distinguished further by the size of humeral spot (3-4 vs. 7-8 horizontal series of scales), and by total number of vertebrae (38-39 vs. 41-43).

Description. Morphometric data for $H$. beni summarized in Table 1. Largest male $81.4 \mathrm{~mm}$ SL, largest female $34.3 \mathrm{~mm}$ SL. Body compressed and moderately elongate; greatest body depth usually at vertical through middle length of pectoral fins. Dorsal profile of head straight to slightly convex. Dorsal body profile convex from occipital bone to base of last dorsalfin ray; straight from this point to adipose-fin origin. Ventral profile of head convex. Ventral body profile convex from pectoral-fin origin to pelvic-fin origin, and straight to slightly convex to anal-fin origin. Body profile along anal-fin base posterodorsally slanted. Caudal peduncle elongate, nearly straight to slightly concave along dorsal and ventral margins.

Snout rounded from margin of upper lip to vertical through anterior nostrils. Head small. Mouth terminal, mouth slit nearly at horizontal through below middle of eye. Maxilla long and slightly curved, aligned at angle of approximately $45^{\circ}$ to longitudinal body axis, and its posterior tip extending below orbit, reaching nearly to vertical through center of eye.

Premaxilla with two teeth rows; outer row with 4-5 tricuspid teeth with central cusp slightly longer; inner row with 4 pentacuspid teeth, gradually decreasing in length from first to third teeth and last tooth smallest; central cusp twice or three times longer and broader than other cusps. Maxilla fully toothed, with 7-14 uni- to tricuspid teeth, with central cusp longer. Three anteriormost dentary teeth larger, with 3-5 cusps, followed by medium sized tooth with 3 cusps, and 8-9 teeth with 1-3 cusps or conical; central cusp in all teeth two to three times longer and broader than other cusps. Cusp tips slightly curved posteriorly and lingually.

Dorsal-fin rays ii,8 (one with ii,7 and one with iii, $8 ; \mathrm{n}=30$ ); first unbranched ray approximately one-half length of second ray. Dorsal-fin origin located posterior to middle of SL and posterior to vertical through pelvic-fin origin. Profile of distal margin of dorsal fin convex. Dorsal fin without bony hooks. Adipose-fin located at vertical through insertion of last or posterior to last anal-fin ray. Anal-fin rays iii-iv, 16-18 (one with 15 and two with 19 , mode $=17, \mathrm{n}=35$, Fig. 2). Anal-fin profile slightly convex in males and nearly straight in females. Anal-fin origin approximately at vertical through insertion in the last dorsal fin rays. Anal-fin rays of males bearing one pair of small bony hooks along posterolateral border of each segment of lepidotrichia, usually along last unbranched ray and third to fourth branched rays. Hooks usually located along posteriormost branch and distal $1 / 2$ to $2 / 3$ of each ray. Pectoral-fin rays i, 10-11 (mode $=10, \mathrm{n}=33)$. Pectoral-fin tip reaching pelvic-fin origin in all specimens. Pectoral fin without bony hooks. Pelvic-fin rays i,6,i (one with i,5,i, $\mathrm{n}=33$ ). Pelvicfin origin located 5-6 predorsal scales anterior to vertical through dorsal-fin origin. Pelvic fin of males usually bearing one small bony hook per segment of lepidotrichia along ventromedial border of second to eighth branched rays. Caudal fin forked with 19 principal rays without bony hooks 


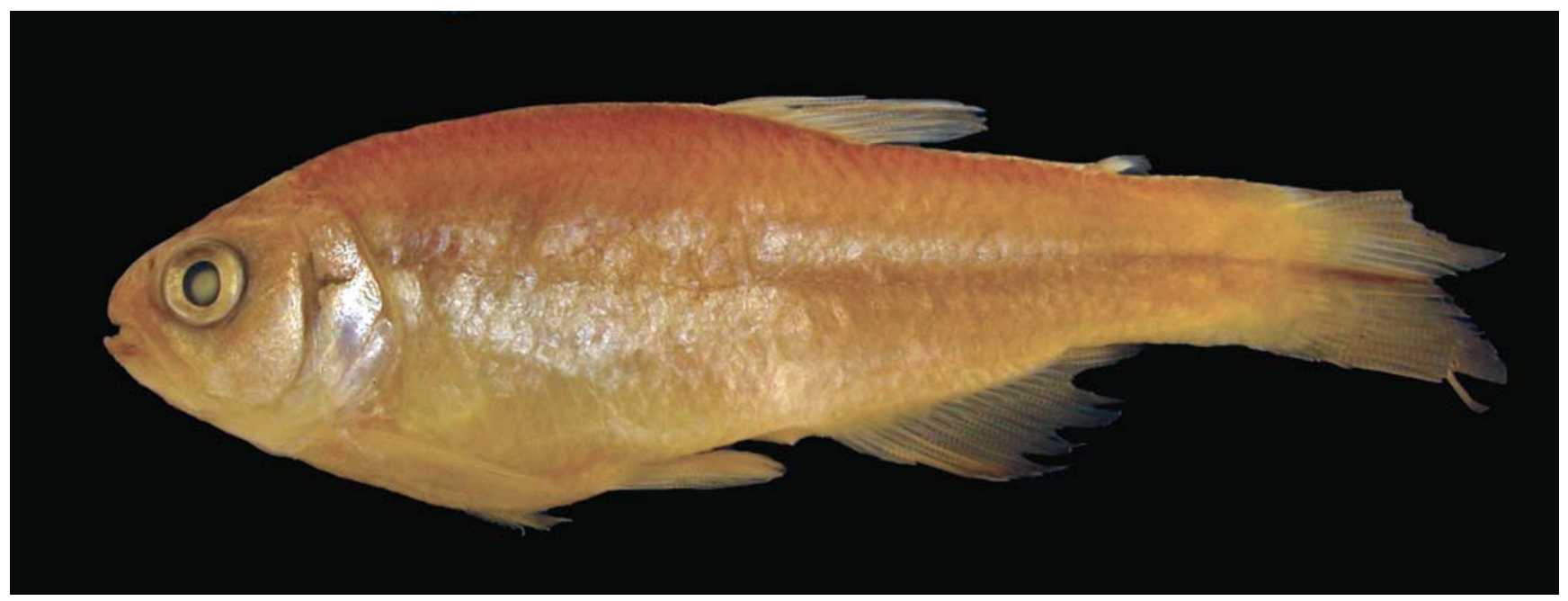

Fig. 1. Hemibrycon beni, CAS 44333, syntype, male, $56.0 \mathrm{~mm}$ SL, upper río Beni basin, Bolivia.

$(\mathrm{n}=33)$; lobes similar in size. Caudal-fin base with a few scales in half-length, followed by one large scale in each lobe. Caudal fin without bony hooks. Dorsal procurrent rays 10-11 and ventral procurrent rays $11(\mathrm{n}=2$, $\mathrm{x}$-ray).

Scales cycloid, moderately large. Lateral line complete with $44-53$ ( $\operatorname{mode}=45, n=32$, Fig. 3 ). Scale rows between dorsalfin origin and lateral line $7-8($ mode $=8, n=33)$; scale rows between lateral line and pelvic-fin origin $6-8($ mode $=7, n=33)$. Predorsal scales 17-20, arranged in regular series $(\operatorname{mode}=18, \mathrm{n}=33)$. Scales rows around caudal peduncle $16-18($ mode $=16, n=32)$. Axillary scale on pelvic-fin origin extends posteriorly covering two scales. Scale sheath along anal-fin base with 5-8 scales in single series, extending to base of most anterior branched rays.

Precaudal vertebrae 18-19; caudal vertebrae 20; total vertebrae 38-39 $(n=3)$. Supraneurals $7(n=1$, x-ray). Gill rakers on upper limb of outer gill arch 6, and on lower limb 10-11 $(n=4)$.

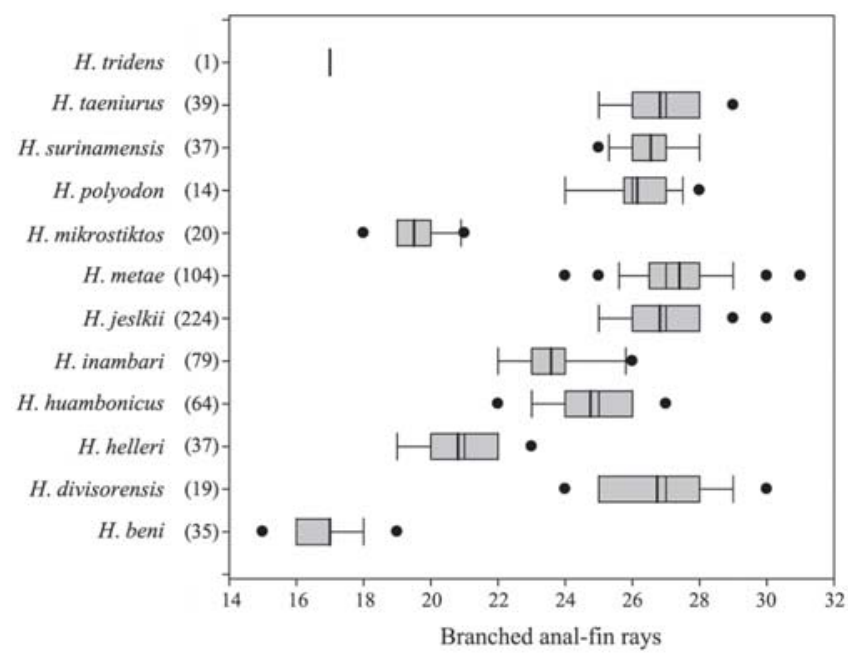

Fig. 2. Tukey box plots of number of branched anal-fin rays in Hemibrycon species. Mean represented by thick vertical bar, and $25^{\text {th }}$ and $75^{\text {th }}$ percetiles as lateral borders of box plots. Number in parentheses $=\mathrm{N}$.
Color in alcohol. Dorsal portion of head and body dark brown. Dorsolateral portion of body with scattered black chromatophores. Midlateral body silvery. One small and vertical black humeral spot, located over third to fourth lateral line scales and extending over 1-2 horizontal series of scales including lateral line, and sometimes over the first horizontal series below lateral line. Base of caudal fin and middle rays black pigmented. Abdominal region almost devoid of black chromatophores. Dorsal, adipose, and caudal fin with dark brown pigmentation diffuse and anal fin with small black chromatophores along its border forming narrow stripe. Caudal peduncle without spot. Pectoral and pelvic fins hyaline (Fig. 1). Body yellowish.

Sexual dimorphism. Males of Hemibrycon beni are easily recognized by the presence of bony hooks on the anal- and pelvic-fin rays. Males and females also slightly differ in body

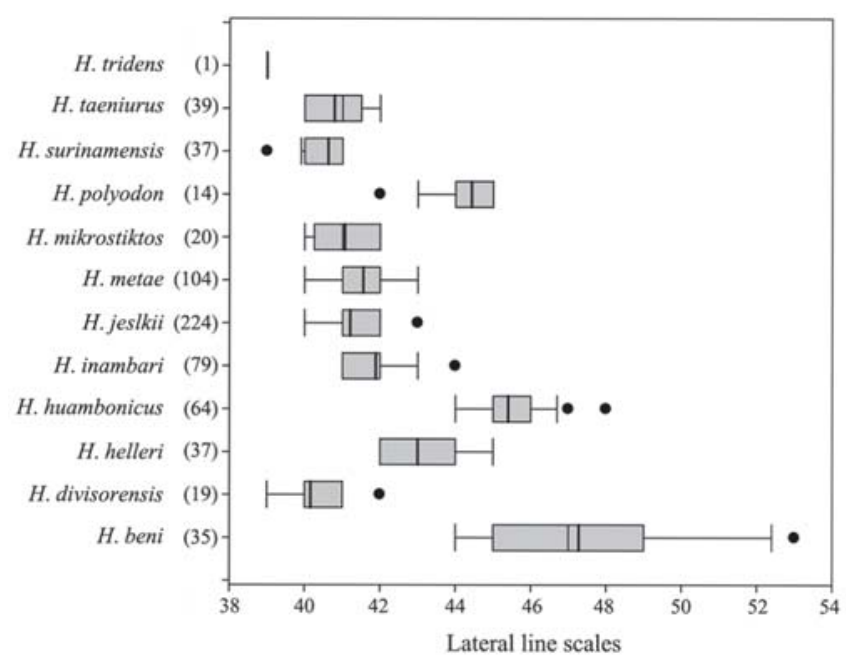

Fig. 3. Tukey box plots of number of lateral line scales in Hemibrycon species. Mean represented by thick vertical bar, and $25^{\text {th }}$ and $75^{\text {th }}$ percetiles as lateral borders of box plots. Number in parentheses $=\mathrm{N}$. 
Table 1. Morphometric data of syntypes of Hemibrycon beni (CAS 44333, 44334; USNM 117543) from río Beni basin, Espia, La Paz, Bolivia, and paratypes of Hemibrycon helleri (CAS 44354; FMNH 58439), and non-types from río Urubamba basin (ANSP 180775, 180777; CAS 70077). m, males; f, females. SD = Standard deviation.

\begin{tabular}{|c|c|c|c|c|c|c|c|c|c|c|c|c|}
\hline & \multicolumn{4}{|c|}{ H. beni } & \multicolumn{8}{|c|}{ H. helleri } \\
\hline & \multicolumn{4}{|c|}{ Syntypes } & \multicolumn{4}{|c|}{ Paratypes } & \multicolumn{4}{|c|}{ Non-types } \\
\hline & $\mathrm{n}$ & Range & Mean & $\mathrm{SD}$ & $\mathrm{n}$ & Range & Mean & SD & $\mathrm{n}$ & Range & Mean & SD \\
\hline Standard length (mm) & 30 & $29.0-81.4$ & 45.5 & - & 8 & $36.4-78.6$ & 53.9 & - & 11 & $43.3-81.6$ & 60.9 & - \\
\hline \multicolumn{13}{|c|}{ Percents of Standard length } \\
\hline Predorsal distance & 30 & $51.8-58.6$ & 54.9 & 1.7 & 7 & $50.8-52.7$ & 52.0 & 0.8 & 11 & $50.5-54.2$ & 52.9 & 1.2 \\
\hline Prepelvic distance & 30 & $41.2-51.0$ & 45.9 & 1.9 & 7 & $43.1-47.9$ & 44.9 & 1.5 & 10 & $42.9-47.0$ & 45.4 & 1.1 \\
\hline Prepectoral distance & 30 & $23.0-28.7$ & 25.7 & 1.2 & 7 & $22.1-25.4$ & 23.7 & 1.1 & 10 & $21.4-26.7$ & 23.5 & 2.0 \\
\hline Preanal distance & 30 & $60.9-67.8$ & 63.3 & 1.6 & 7 & $59.2-61.2$ & 60.2 & 0.9 & 11 & $57.9-63.9$ & 61.4 & 1.8 \\
\hline Depth at dorsal-fin origin(m) & 23 & $29.6-35.6$ & 32.3 & 1.7 & 2 & $30.6-30.9$ & 30.7 & 0.2 & 2 & $28.7-29.6$ & 29.2 & 0.8 \\
\hline Depth at dorsal-fin origin(f) & 7 & 29.4-33.1 & 31.2 & 1.1 & 6 & $29.3-34.5$ & 32.1 & 1.8 & 8 & $28.5-32.4$ & 30.8 & 1.4 \\
\hline Caudal peduncle depth & 30 & $10.6-14.6$ & 12.7 & 1.0 & 8 & $11.9-14.3$ & 12.7 & 0.7 & 11 & $10.5-13.3$ & 12.2 & 0.7 \\
\hline Caudal peduncle length & 30 & $14.0-19.6$ & 17.9 & 1.4 & 8 & $12.4-17.0$ & 15.6 & 1.5 & 11 & $14.3-16.4$ & 15.3 & 0.7 \\
\hline Anal-fin base & 30 & $19.1-25.0$ & 22.1 & 1.4 & 8 & $27.3-29.3$ & 28.2 & 0.6 & 11 & $25.1-29.6$ & 27.2 & 1.4 \\
\hline Dorsal-fin length & 30 & $21.6-26.7$ & 24.0 & 1.2 & 8 & $20.8-24.6$ & 22.2 & 1.3 & 5 & $20.4-22.7$ & 21.4 & 0.9 \\
\hline Pelvic-fin length (m) & 23 & $14.8-18.2$ & 16.3 & 0.9 & 2 & $11.8-13.0$ & 12.4 & 0.8 & 2 & $13.1-13.3$ & 13.2 & 0.1 \\
\hline Pelvic-fin length (f) & 7 & $14.0-15.3$ & 14.8 & 0.5 & 6 & $13.5-14.3$ & 13.9 & 0.3 & 3 & $13.1-14.5$ & 13.7 & 0.4 \\
\hline Pectoral-fin length (m) & 23 & $18.8-22.1$ & 20.4 & 0.8 & 2 & $18.7-20.2$ & 19.4 & 1.0 & 2 & $20.2-20.2$ & 20.2 & 0.0 \\
\hline Pectoral-fin length (f) & 7 & $20.4-21.8$ & 21.3 & 0.6 & 6 & $19.7-21.7$ & 20.5 & 0.7 & 3 & $20.4-21.5$ & 20.8 & 0.5 \\
\hline Head length & 30 & $24.1-28.8$ & 26.2 & 1.2 & 7 & $22.4-25.1$ & 23.6 & 0.8 & 11 & $21.9-25.3$ & 23.5 & 0.9 \\
\hline \multicolumn{13}{|c|}{ Percents of Head length } \\
\hline Snout length & 30 & $20.0-26.0$ & 22.7 & 1.1 & 7 & $19.9-24.6$ & 22.1 & 1.5 & 11 & $19.7-23.0$ & 21.4 & 1.0 \\
\hline Upper jaw length & 29 & $40.8-53.2$ & 47.1 & 2.1 & 7 & $42.1-47.6$ & 45.4 & 1.8 & 11 & $43.2-49.3$ & 46.0 & 1.8 \\
\hline Orbital diameter & 30 & $25.4-38.2$ & 30.7 & 2.4 & 7 & $28.4-33.5$ & 31.1 & 1.7 & 11 & $25.4-32.0$ & 28.9 & 2.4 \\
\hline Interorbital width & 30 & $29.1-35.3$ & 31.9 & 1.3 & 7 & $30.9-33.7$ & 32.2 & 1.1 & 11 & $30.5-38.3$ & 33.9 & 2.1 \\
\hline
\end{tabular}

depth (Table 1), and in anal-fin shape, which is slightly convex in males and nearly straight in females. Gill glands were not found on first gill arch in either males or females.

Distribution. Hemibrycon beni is known from río Beni drainage, upper río Madeira basin, where ríos La Paz and Miguilla join to form río Bopi, Espia, La Paz, Bolivia (Fig. 4).

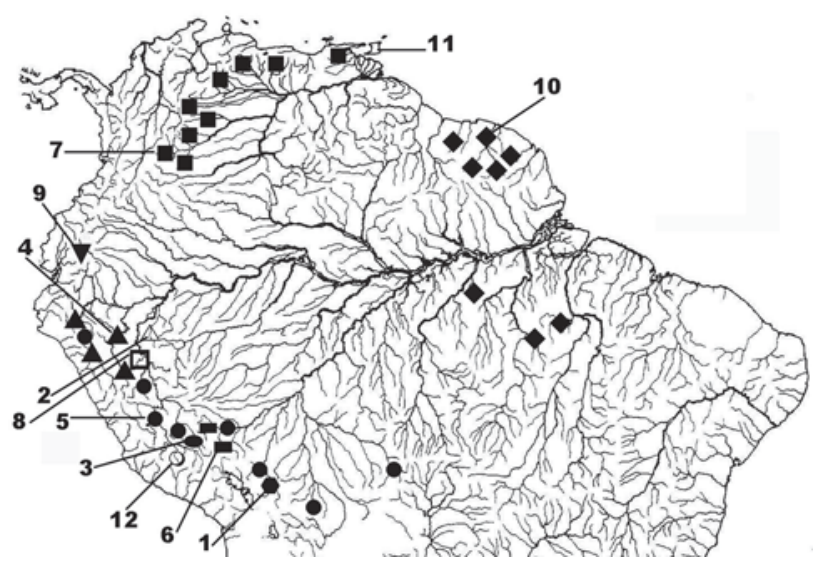

Fig. 4. Map of central and northern South America showing geographic distribution of Hemibrycon beni (1, solid hexagon), $H$. divisorensis (2, open triangle), $H$. helleri (3, ellipse), $H$. huambonicus (4, solid triangles), H. jelskii (5, solid dots), $H$. inambari (6, rectangles), $H$. metae (7, solid squares), $H$. mikrostiktos (8, open square), $H$. polyodon $(9$, inverted triangle), H. surinamensis (10, solid diamonds), H. taeniurus (11, Trinidad Island), H. tridens (12, open circle). Some symbols represent more than one lot or locality of specimens. $1-12=$ type locality of each species.
Remarks. Hemibrycon beni was described by Nathan Pearson based on specimens collected by the Mulford Expedition, Bolivia, in 1921. In the original description, Pearson designated 48 "cotypes" in good condition plus 58 "dried during shipment”, all specimens catalogued under IU 17321, and further listed six specimens not identified as types (IU 17347, now CAS 44335). Of the original 106 cotypes under IU 17321, however, there are 107 presently catalogued as cotypes under CAS 44333, 29 specimens, CAS 44334, 60 specimens, USNM 117543, 2 specimens, and UMMZ 66504, 16 specimens. This last lot was not examined. All specimens of the lot CAS 44334 are very dry but the remaining syntypes are in good condition.

Material examined. Syntypes. CAS 44333, 29 (1 x-ray), 24.156.0 mm SL, CAS 44334, 60, 27.4-81.4 mm SL, USNM 117543, 2 (x-ray), 31.6-42.1 mm SL, where ríos La Paz and Miguilla join to form río Bopi, río Beni drainage, elev. 3,080 ft., Espia, La Paz, Bolivia, ca. $16^{\circ} 16^{\prime}$ 'S $67^{\circ} 12^{\prime}$ W, Jul 1921, N. E. Pearson. Non-type specimens. CAS 44335, 6, 22.5-24.8 mm SL, río Colorado, tributary to lower río Bopi $10 \mathrm{mi}$ above Huachi, Mulford Exploration of the Amazon Basin, La Paz, Bolivia, ca. 1605’S 67¹2’W, Sep 1921.

\section{Hemibrycon helleri Eigenmann, 1927} Figs. 5-6

Hemibrycon helleri Eigenmann, 1927: 402 (in key), 406 (pl. 96, fig. 2; original description; type material; type locality: río Comberciato, río Urubamba drainage).

Diagnosis. Hemibrycon helleri is distinguished from all congeners, except $H$. jelskii, by the size of humeral spot (over 7-8 vs. 3-6 horizontal series of scales). It differs from $H$. jelskii by the number of branched anal-fin rays (19-23 vs. 25-30, Fig. 2), 


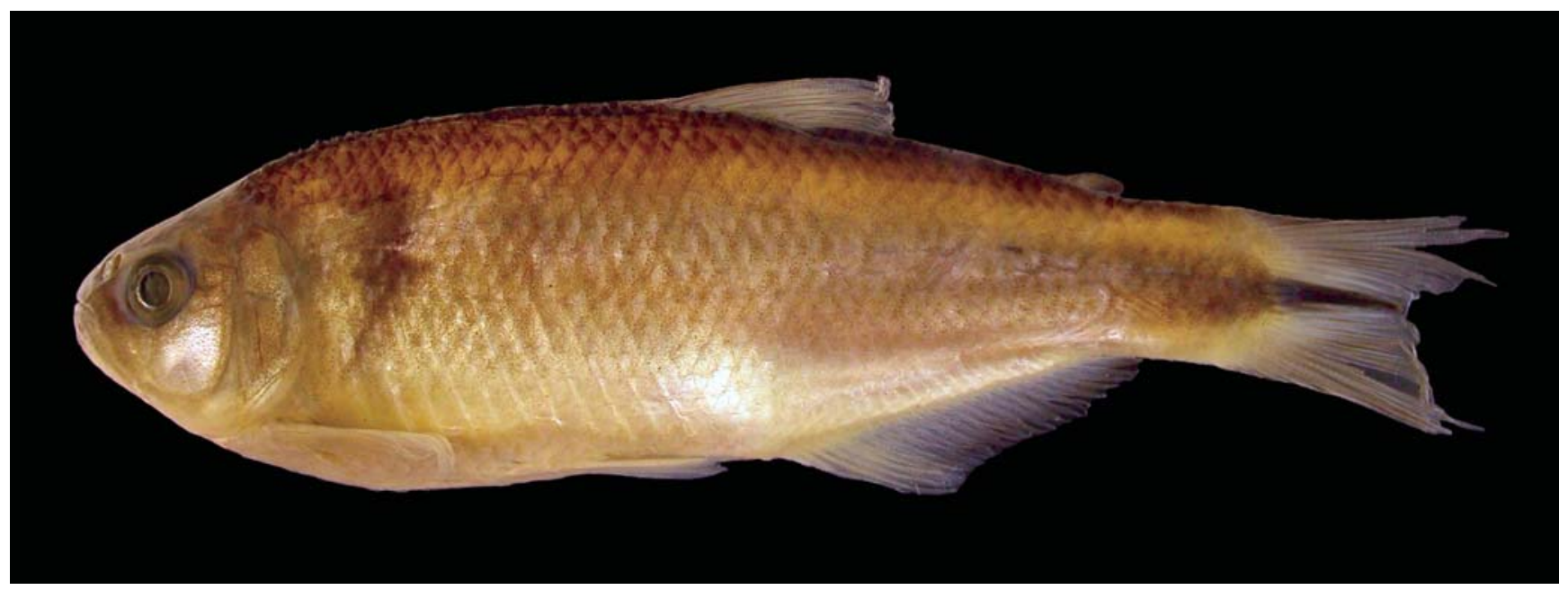

Fig. 5. Hemibrycon helleri, ANSP 180775, female, $81.1 \mathrm{~mm}$ SL, upper río Ucayali basin, Peru.

and by the number of scales along anal-fin base scale sheath (6-12 vs. 13-28). Hemibrycon helleri is rather similar to $H$. inambari new species, but can be distinguished by the size of humeral spot (over 7-8 vs. 5-6 horizontal series of scales), number of predorsal scales (16-18 vs. 13-16), and by the total number of vertebrae (41-43 vs. 39-40).

Description. Morphometric data for $H$. helleri summarized in Table 1. Largest male $78.6 \mathrm{~mm}$ SL, largest female $81.6 \mathrm{~mm}$ SL. Body compressed and moderately elongate; greatest body depth at vertical through middle length of pectoral fins. Dorsal profile of head straight to slightly convex. Dorsal body profile convex from occipital bone to base of last dorsal-fin ray; straight from this point to adipose-fin origin. Ventral profile of head nearly straight to slightly convex. Ventral body profile convex from pectoral-fin origin to pelvic-fin origin, and straight to slightly convex to anal-fin origin. Body profile along analfin base posterodorsally slanted. Caudal peduncle elongate, nearly straight to slightly concave along dorsal and ventral margins.

Snout rounded from margin of upper lip to vertical through anterior nostrils. Head small. Mouth terminal, mouth slit nearly at horizontal through middle of eye. Maxilla long and slightly curved, aligned at angle of approximately $45^{\circ}$ to longitudinal body axis, and its posterior tip extending below orbit, reaching nearly to vertical through center of eye.

Premaxilla with two tooth rows; outer row with 3-5, tricuspid teeth with central cusp slightly longer; inner row with 4 tetra- to pentacuspids teeth, gradually decreasing in length from first to third teeth and last tooth smallest; central cusp twice or three times longer and broader than other cusps. Maxilla fully toothed with 8-14 uni- to tricuspid teeth, with central cusp longer. Three anteriormost dentary teeth larger, with 5 cusps, followed by medium sized tooth with 3 cusps, and 7-9 teeth with 1-3 cusps or conical; central cusp in all teeth two to three times longer and broader than other cusps. Cusp tips slightly curved posteriorly and lingually (Fig. 6).
Dorsal-fin rays ii, $8(\mathrm{n}=33)$; first unbranched ray approximately one-half length of second ray. Dorsal-fin origin located posterior to middle of SL and posterior to vertical through pelvic-fin origin. Profile of distal margin of dorsal fin nearly straight to slightly concave. Males with bony hooks in distal one-third of first branched rays. Adipose-fin located at vertical through insertion of last or posterior to last anal-fin ray. Analfin rays ii-v, 19-23 (mode $=21, n=37$, Fig. 2 ). Anal-fin profile slightly convex in males and nearly straight in females. Analfin origin approximately at vertical through insertion in the last dorsal fin rays. Anal-fin rays of males bearing one pair of small bony hooks along posterolateral border of each segment of lepidotrichia, along last unbranched ray and twelfth to sixteenth branched rays. One male paratype had bony hooks in all analfin branched rays. Hooks usually located along posteriormost branch and distal $1 / 2$ to ${ }_{3}$ of each ray. Pectoral-fin rays i,10-11

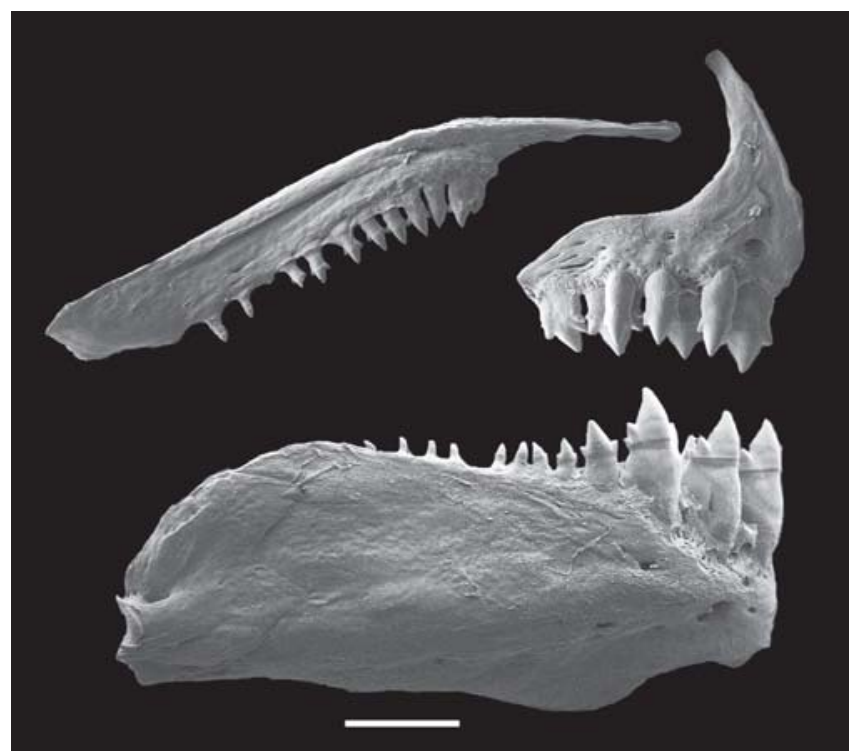

Fig. 6. Hemibrycon helleri, ANSP 180775, female, 66.6 mm SL. Scanning electron micrograph of right side upper and lower jaws. Scale bar $=1 \mathrm{~mm}$. 
( mode $=10, \mathrm{n}=27)$. Pectoral-fin tip reaching pelvic-fin origin in males. Males with bony hooks on distal portion of unbranched and all branched rays. Pelvic-fin rays i,6,i $(n=30)$. Pelvic-fin origin located 4-5 predorsal scales anterior to vertical through dorsal-fin origin. Pelvic fin of males usually bearing one small bony hook per segment of lepidotrichia along ventromedial border of fourth to eighth branched rays. Caudal fin forked with 19 principal rays without bony hooks $(n=30)$; lobes similar in size. Caudal-fin base with a few scales in half-length, followed by one large scale in each lobe. Dorsal procurrent rays 8-10 and ventral procurrent rays $9-10(n=12)$.

Scales cycloid, moderately large. Lateral line complete with $42-45$ ( $\operatorname{mode}=42, n=23$, Fig. 3 ). Scale rows between dorsalfin origin and lateral line $7-8($ mode $=8, \mathrm{n}=35)$; scale rows between lateral line and pelvic-fin origin 5-6 (mode $=6, \mathrm{n}=35)$. Predorsal scales 15-18, arranged in regular series $($ mode $=16, \mathrm{n}=34)$. Scales rows around caudal peduncle $16-18(\operatorname{mode}=16, \mathrm{n}=27)$. Axillary scale on pelvic-fin origin extends posteriorly covering 2-3 scales. Scale sheath along anal-fin base with 6-12 scales in single series, extending to base of most anterior branched rays.

Precaudal vertebrae 19-21; caudal vertebrae 22-23; total vertebrae 41-43 $(n=12)$. Supraneurals 6-7 $(n=12)$. Gill rakers on upper limb of outer gill arch 6-7, and on lower limb 10-11 ( $\mathrm{n}=11)$.

Color in alcohol. Type material discolored. Color based on the non-type specimens. General ground body color yellowish. Dorsal portion of head and body with dense concentration of black chromatophores. Dorsolateral portion of head and body with scattered black chromatophores. Midlateral body silvery. One large and vertical black humeral spot, located over fourth to sixth lateral line scales and extending over 7-8 horizontal series of scales, including lateral line. Midlateral dark stripe extending from humeral region to middle caudal-fin rays, broad in the caudal peduncle. Abdominal region almost devoid of black chromatophores. Adipose fin densely black pigmented. Dorsal and caudal fin with black pigmentation diffuse and anal fin with small black chromatophores along its border forming narrow stripe. Pectoral and pelvic fins hyaline (Fig. 5).

Sexual dimorphism. Males of Hemibrycon helleri are easily recognized by the presence of bony hooks on the dorsal-, pectoral-, anal- and pelvic-fin rays. Males and females also slightly differ in body depth (Table 1), and in anal-fin shape, which is slightly convex in males and nearly straight in females. Mature males with gill gland on first gill arch, covering the first branchial filaments (Fig. 7).

Distribution. Hemibrycon helleri is known from río Comberciato, and río Urubamba, upper río Ucayali drainage, Cusco, Peru (Fig. 4).

Remarks. Eigenmann (1927: 406) described Hemibrycon helleri and designated the holotype as "13565 Type" [MCZ 31565, the catalog number mistakely cited in the original description] and 17 paratypes (CM 7439, IU 13754) from río Comberciato, Peru.
Later, Eigenmann \& Allen (1942: 216) listed the type material but did not provided the catalog number for types of $H$. helleri, but listed 18 type specimens along with their lengths, and type locality. Böhlke (1953) in his catalog of types from Stanford University did not list types of $H$. helleri. Ibarra \& Stewart (1987: 43) listed three paratypes of $H$. helleri but did not provide the catalog number of FMNH specimens. Eschmeyer (1998: 717) listed two possible lots as holotype, "?MCZ 31565" (1) or MCZ 30980 (1), and the following lots as paratypes: CAS 44354 [ex IU 13754] (5) and FMNH 58439 (3), followed posteriorly by Lima et al. (2003: 129); there are 8 paratypes missing.

According to Eigenmann (1927) the holotype has $100 \mathrm{~mm}$ of size [total length - TL]. The specimen from MCZ 31565 measures $78.9 \mathrm{~mm}$ SL and $94.9 \mathrm{~mm}$ TL and the specimen from MCZ 30980 has $81.1 \mathrm{~mm}$ SL and $98.9 \mathrm{~mm}$ TL. Although the specimen from MCZ 30980 is larger and more close to the body size of the holotype mentioned by Eigenmann $(100 \mathrm{~mm}$ $\mathrm{TL}$ ), the specimen corresponding to the original catalog number referred as the holotype MCZ 31565 (mistyped 13565) has the same number of branched anal-fin rays of the specimen illustrated as the holotype in the figure 2 by Eigenmann (1927, plate 96), 23 vs. 22 branched anal-fin rays on specimen of lot MCZ 30980, and so we consider that the specimen available as MCZ 31565 is actually the holotype. Based on data and fish images taken from the lots MCZ 30980 (1), and MCZ 30981 (7) we can confirm that these specimens are part of the missing type series of $H$. helleri. The specimen listed as nontype by Eigenmann (1927: 406; CAS 44355, ex IU 17611) from río Crisnejas, Peru is actually a specimen of H. huambonicus.

Material examined. Holotype. MCZ 31565, female (x-ray), 78.9 $\mathrm{mm} \mathrm{SL}$, río Comberciato, a small tributary of middle río Urubamba, 30 miles above the Pongo de Mainique, Cusco, Peru, 1,800 ft. elev., ca. $12^{\circ} 28^{\prime} \mathrm{S} 73^{\circ} 07^{\prime} \mathrm{W}, 1910-1915$, E. Heller (Yale-National Geographic Expedition). Paratypes. CAS 44354, 5, 39.6-72.0 mm SL, FMNH 58439, 3 (x-ray), 36.4-78.5 mm SL, MCZ 30980, 1 (x-ray), 81.1 mm SL, MCZ 30981, 8 (x-ray), 46.1-79.2 mm SL, collected with the holotype. Non-type specimens. Peru, Cusco, río Urubamba drainage: ANSP 180775, 4 (1 c\&s), 53.3-81.1 mm SL, quebrada Rosaríomayo, west of Quelluono on road to Kiteni, 1246'28'S 72³9'06”'W, 19 Jul 2004. ANSP 180777, 2, 20.4-72.4 $\mathrm{mm}$ SL, río Amaybamba, southeast of Quillabamba on road to Ollantaytambo, 12 59'55"S 72³1'24'W, 17 Jul 2004. ANSP 180780, 1, $23.5 \mathrm{~mm}$ SL, Yanayaku Grande, tributary of río Urubamba, southeast of Quillabamba on road to Ollantaytambo, 12'59'49"S 72³2'06”'W, 17 Jul 2004. CAS 70077, 15, 27.5-81.5 mm SL, río de Santa Ana, creek entering middle río Urubamba at $c a .3000-3400 \mathrm{ft}$. elev., the farthest point reached by the Eigenmann's on río Urubamba, ca. $12^{\circ} 52^{\prime} \mathrm{S} 72^{\circ} 43^{\prime} \mathrm{W}, 15$ Nov 1918.

\section{Hemibrycon huambonicus (Steindachner, 1882) Figs. 8-9}

Tetragonopterus huambonicus Steindachner, 1882: 177 (original description, type locality: Huambo [Peru]).

Hemibrycon huambonicus. -Eigenmann, 1910: 432 (synonym of H.polyodon (Günther)). -Eigenmann, 1927: 402 (in key), 410-411 (redescription, and valid species). 


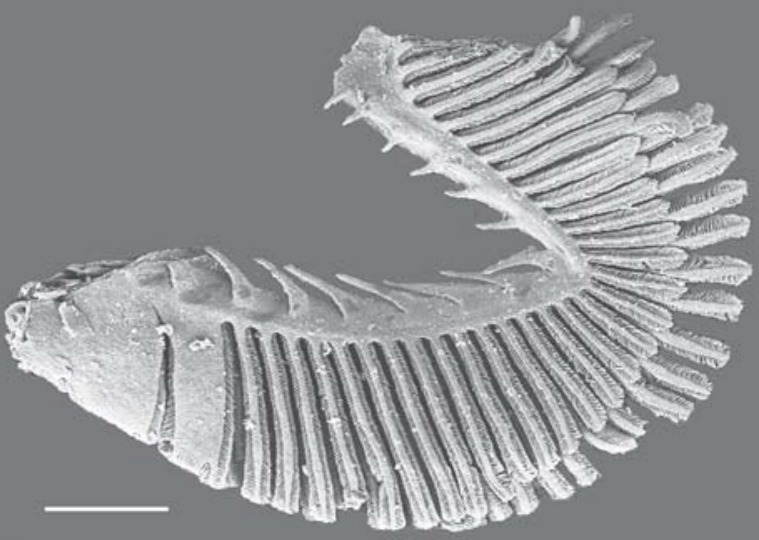

a

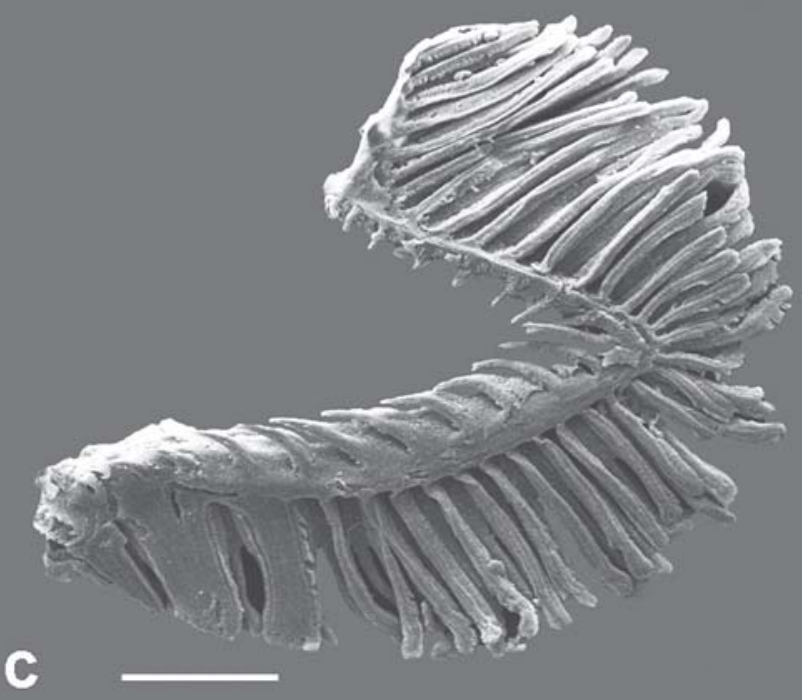

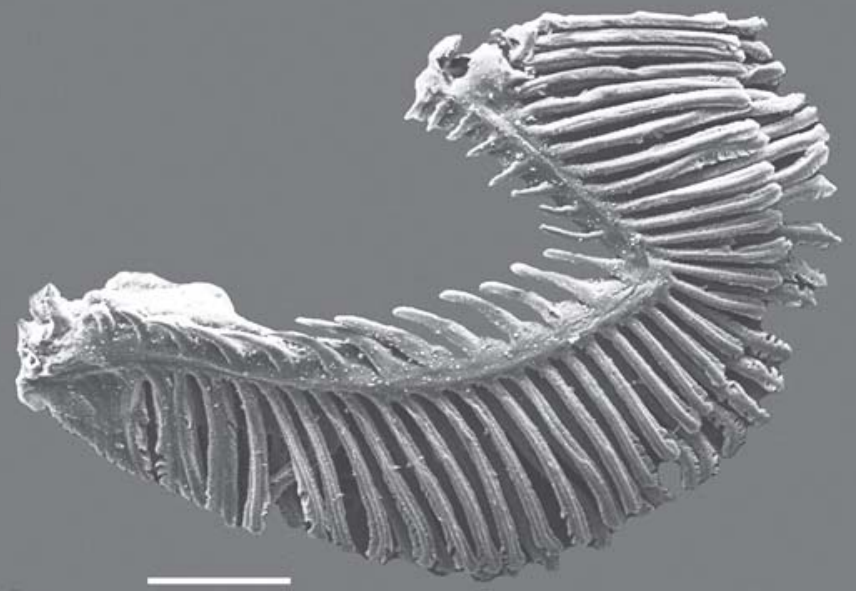

(2)

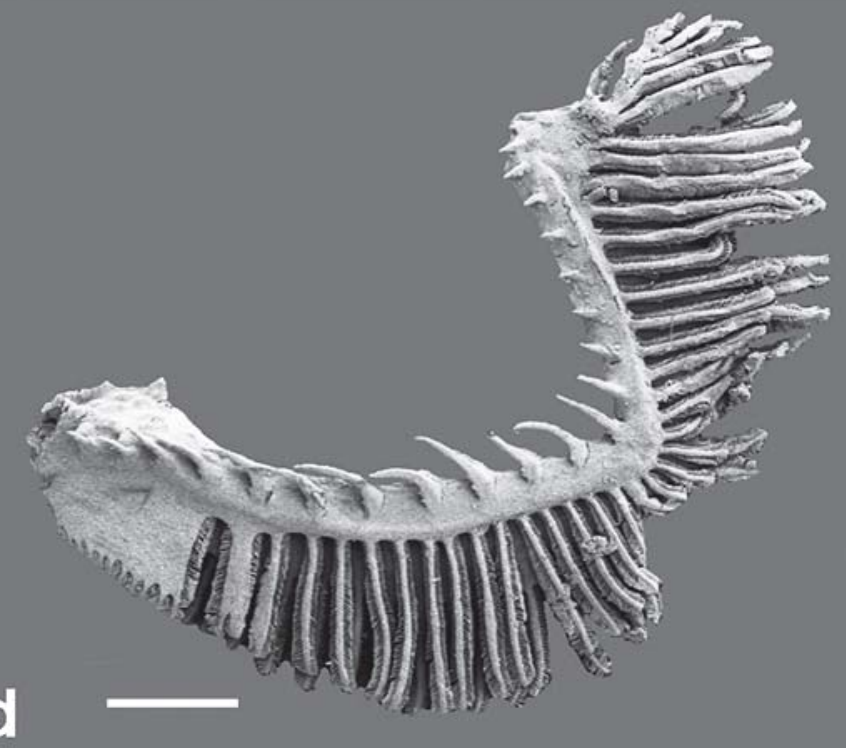

Fig. 7. First gill arch showing gill gland. Lateral view of the left side of (a) Hemibrycon helleri, ANSP 180775, (b) Hemibrycon metae, USNM 228563; (c) Hemibrycon huambonicus, USNM 086794; (d) Hemibrycon jelskii, MCP 35022 . Scale bars $=1 \mathrm{~mm}$.

Diagnosis. Hemibrycon huambonicus is distinguished from most of its congeners by the number of lateral line scales (4448 vs. 39-43 or 48-58, Fig. 3). From the species sharing similar lateral line counts, it differs from $H$. beni, and $H$. dentatus by the number of branched anal-fin rays (22-27 vs. 15-19 and 2834 , respectively); from $H$. cairoense by the number of scale rows above lateral line (8-10 vs. 6-7); from $H$. helleri by the number of scales along anal-fin base scale sheath (17-26 vs. 612) and the number of scale rows above lateral line (8-10 vs. 78 ), from $H$. polyodon by the number of caudal peduncle scales (18-20 vs. 16), head length (22.0-26.0 vs. 20.9-22.9\% SL), and upper jaw length (45.2-52.6 vs. 43.7-45.6\% HL), and from $H$. raqueliae by the number of predorsal scales (15-19 vs. 10-13) and by the number of cusps of first maxillary tooth (3vs. 5).

Description. Morphometric data for H. huambonicus summarized in Table 2. Largest male $87.0 \mathrm{~mm} \mathrm{SL}$, largest female
109.9 mm SL. Body compressed and elongate; greatest body depth at vertical through middle length of pectoral fins. Dorsal profile of head nearly straight to slightly convex. Dorsal body profile convex from occipital bony to base of last dorsal-fin ray; straight from this point to adipose-fin origin. Ventral profile of head slightly convex. Ventral body profile convex from pectoral-fin origin to pelvic-fin origin and straight to anal-fin origin. Body profile along anal-fin base posterodorsally slanted. Caudal peduncle elongate, nearly straight to slightly concave along dorsal and ventral margins.

Snout rounded from margin of upper lip to vertical through anterior nostrils. Head heavy (massive) and relatively small. Mouth terminal, mouth slit nearly at horizontal through below middle of eye. Maxilla long and slightly curved, aligned at angle of approximately $45^{\circ}$ to longitudinal body axis, and its posterior tip extending below orbit, reaching nearly to vertical through center of eye. 
Table 2. Morphometric data of syntype of Hemibrycon huambonicus (S, NMW 57531) from Huambo, Peru, non-types from the upper río Huallaga basin (CAS 70082, 70085, 70089, 70091-93; ICNMHN 7317), and from the upper río Marañon basin (CAS 70083, 70086; ROM 55238, 55406, 55366); and holotype (H, MUSM 35491) and paratypes of Hemibrycon inambari from the upper río Madre de Dios basin(ANSP 143290, 143293, 143307, 143291, 143294, 143300, 143306, 143312, 143317, 151478, 151497, 151526, MCP 45753, MUSM 26299, 26776, 26802, UFRGS 13201). The range includes the holotype. m, males; f, females. SD=Standard deviation.

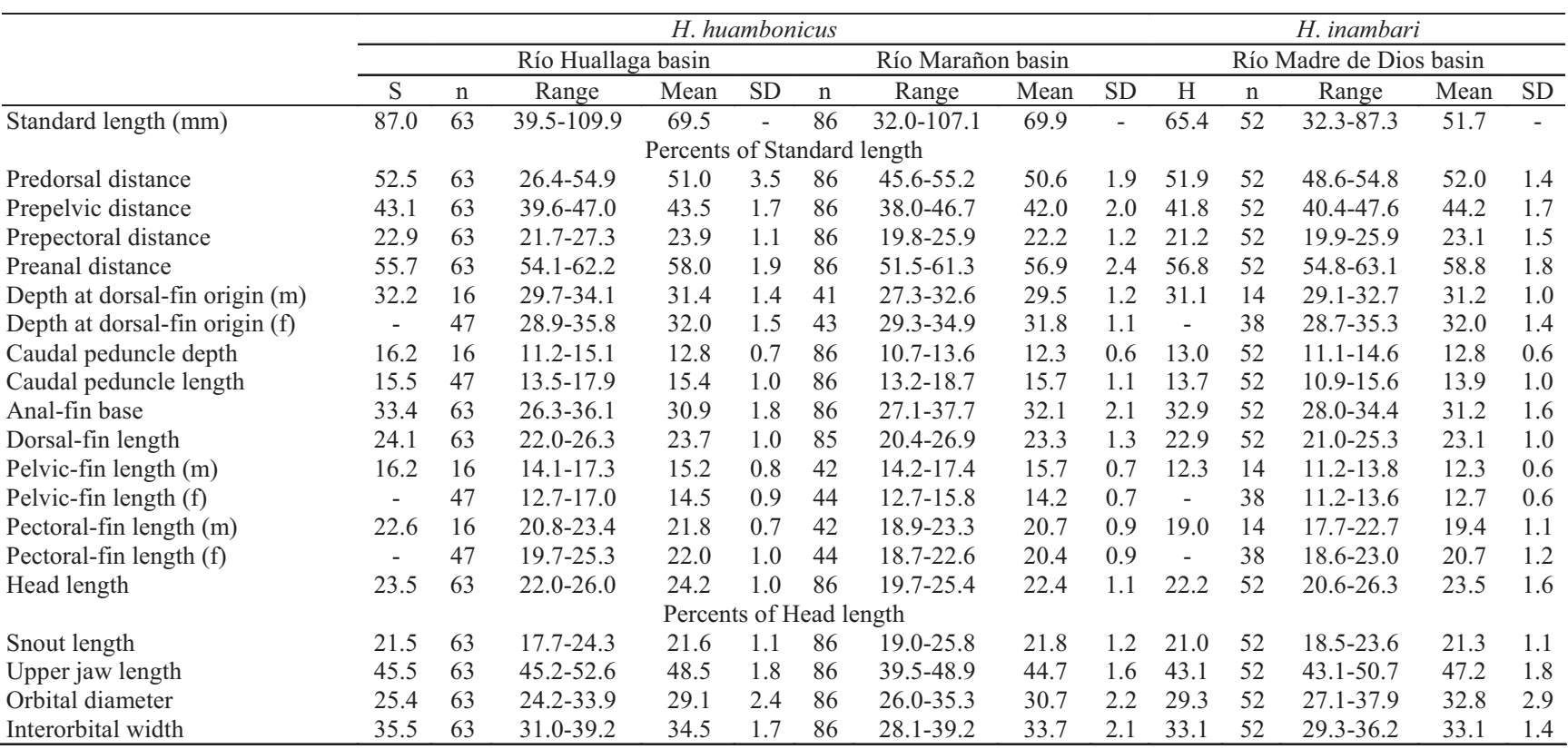

Premaxilla with two tooth rows; outer row with 4-6, tricuspid teeth with central cusp slightly longer; inner row with 4 pentacuspid teeth, gradually decreasing in length from first to third teeth and last tooth smallest; central cusp twice or three times longer and broader than other cusps. Maxilla almost fully toothed with 7-13 uni- to tricuspid teeth, with central cusp longer. Three anteriormost dentary teeth larger, with 5 cusps, followed by medium sized tooth with 3-5 cusps, and 7-10 teeth with 1-3 cusps or conical; central cusp in all teeth two to three times longer and broader than other cusps. Cusp tips slightly curved posteriorly and lingually (Fig. 9).

Dorsal-fin rays ii,8 $(n=64)$; first unbranched ray approximately one-half length of second ray. Dorsal-fin origin located approximately to middle of SL and posterior to vertical through pelvic-fin origin. Males with bony hooks in distal one-third of first branched rays. Profile of distal margin of dorsal fin nearly straight to slightly concave. Adipose-fin located at vertical through insertion of two last anal-fin rays. Anal-fin rays iii-v,2227 ( mode $=24, n=64$, Fig. 2). Anal-fin profile slightly concave in males and nearly straight in females. Anal-fin origin approximately at vertical through insertion in the last dorsal fin rays. Anal-fin rays of males bearing one pair of developed bony hooks along posterolateral border of each segment of lepidotrichia, usually along last unbranched ray and first twelve branched rays. Only two males (syntype and non-type male) possess bony hooks in all anal-fin rays. Hooks usually located along posteriormost branch and distal $1 / 2$ to $2 / 3$ of each ray. Pectoral-fin rays i,10-12 (mode $=11, \mathrm{n}=64)$. Pectoral-fin tip surpassing pelvic-fin origin in males, and reaching in females. Males with bony hooks on distal portion of unbranched and all branched rays. Pelvic-fin rays $i, 6, i$ or $i, 7(n=64)$. Pelvic-fin origin located $4-5$ predorsal scales anterior to vertical through dorsal-fin origin. Pelvic fin of males usually bearing one small bony hook per segment of lepidotrichia along ventromedial border of all branched rays. Caudal fin forked with 19 principal rays $(n=64)$; lobes in similar size. First third of caudal-fin scaled. Dorsal procurrent rays 11 and ventral procurrent rays 11-12 $(n=4)$.

Scales cycloid, moderately large. Lateral line complete with $44-48$ ( $\operatorname{mode}=45, n=64$, Fig. 3 ). Scale rows between dorsal-fin origin and lateral line $8-10($ mode $=9, \mathrm{n}=64)$; scale rows between lateral line and pelvic-fin origin 6-7 (mode $=7, n=64)$. Predorsal scales 15-19, arranged in regular series $($ mode $=17, \mathrm{n}=62)$. Scales rows around caudal peduncle 18-20 $(\mathrm{n}=64)$. Axillary scale on pelvic-fin origin extends posteriorly covering 2-3 scales. Scale sheath along anal-fin base with 17-26 scales in single series, extending to base to $18^{\text {th }}$ to $24^{\text {th }}$ branched rays.

Precaudal vertebrae 20-21; caudal vertebrae 22-24; total vertebrae 42-43 (x-ray of syntype). Supraneurals 8-9. Gill rakers on upper limb of outer gill arch 7-8, and on lower limb 11-12 ( $n=12)$.

Color in alcohol. General ground body color brown yellowish. Dorsal portion of head and body with concentration of black chromatophores. Dorsolateral portion of head and body with scattered black chromatophores. One vertical black humeral spot, located over fourth to sixth lateral line scales and extending over 5-6 horizontal series of scales, including lateral line. Caudal peduncle and middle caudal-fin rays dark pigmented. Abdominal region almost devoid of black chromatophores. Dorsal, adipose and caudal fin with dark pigmentation diffuse, and pectoral and pelvic fins hyaline (Fig. 8). 


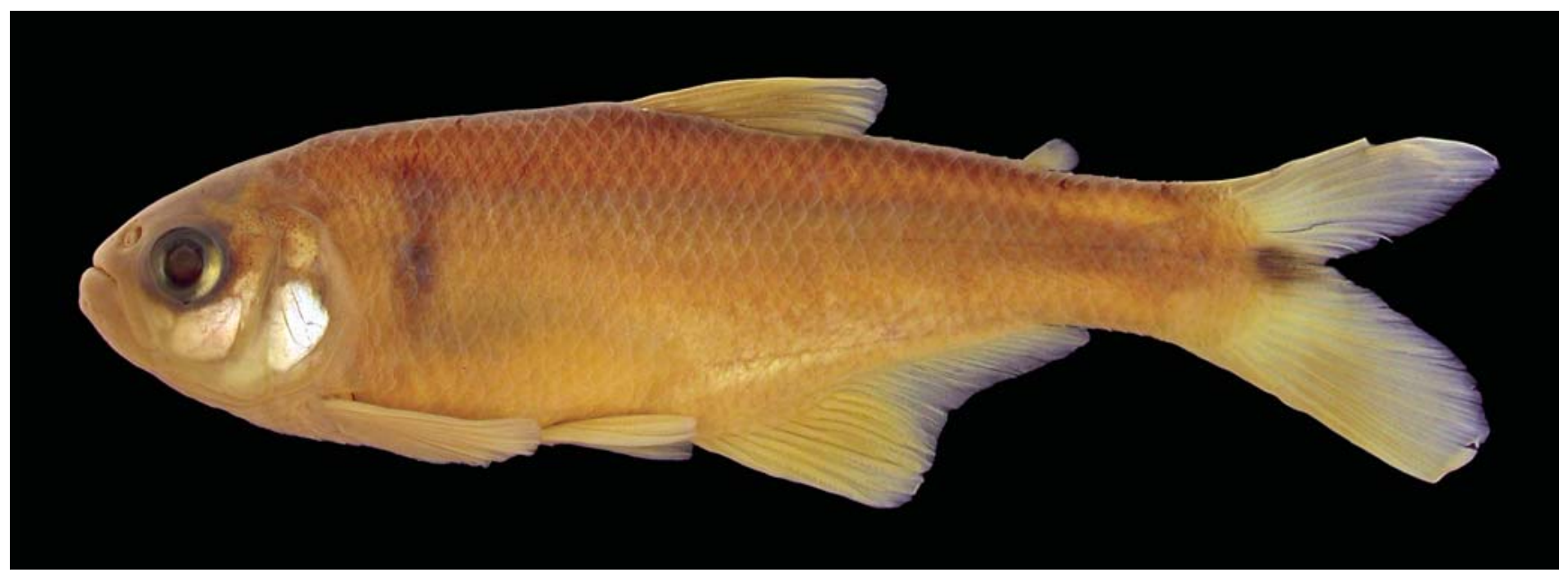

Fig. 8. Hemibrycon huambonicus, ROM 55406, male, $73.3 \mathrm{~mm} \mathrm{SL}$, upper río Ucayali basin, Peru.

Sexual dimorphism. Males of Hemibrycon huambonicus are easily recognized by the presence of bony hooks in dorsal, anal, pelvic and pectoral fin rays. Males and females also slightly differ in pectoral- and pelvic-fin lengths and body depth (Table 2), and in anal-fin shape, slightly concave in males and nearly straight in females. Mature males with gill gland on first gill arch, covering the first branchial filaments (Fig. 7).

Distribution. Hemibrycon huambonicus is known from río Huambo, río Crisnejas and río Tingo, all tributaries of río Huallaga drainage, and río Marañon drainage, upper río Amazonas basin, Peru (Fig. 4).

Remarks. The original description of H. huambonicus provided by Steindachner (1882) is relatively brief, with the type locality reported only for Huambo (Peru). In Peru, there are two possible localities for Huambo: (1) río Huambo, San Martin, Peru, ca. $07^{\circ} 04^{\prime} \mathrm{S} 77^{\circ} 10^{\prime} \mathrm{W}$, upper río Huallaga drainage, and (2) río Huambo, Huanuco, ca. 09³9'S 7456'W, río Pachitea and río Ucayali drainage. All lots analyzed and identified as $H$. huambonicus are from río Huallaga and río Marañon drainages.

Geographic variation. The population of $H$. huambonicus from río Marañon drainage has head length slightly smaller (19.7-25.4 vs. 22.0-26.0\% SL), and upper jaw length smaller (39.5-48.9 vs. $45.2-52.6 \% \mathrm{HL})$ than the population from río Huallaga drainage. However, no other significant difference was found between these populations for the recognition of a distinct species.

Material examined. Syntype. NMW 57531, male (x-ray), 87.0 $\mathrm{mm}$ SL, Huambo, Peru [río Huambo, Huanuco, ca. 09³9'S 7456'W, río Pachitea and río Ucayali drainage]. Non-type specimens. Peru. Río Huallaga drainage: CAS 70082, 5, 64.1-95.2 mm SL, río Huallaga at Ambo (or Tambo), ca. 7,500 ft. elev., Huanuco, ca. $10^{\circ} 08^{\prime} \mathrm{S} 76^{\circ} 10^{\prime} \mathrm{W}, 26-29$ Oct 1918 . CAS 70085, 6, 59.9-86.1 mm SL, río Huallaga at Huanuco, ca. 6,000 ft. elev., Huanuco, ca. $09^{\circ} 55^{\prime} \mathrm{S}$ 76²13'W Oct 1918. CAS 70089, 51, 30.7-81.2 mm SL, río Tingo
(= río Higueros) into río Huallaga from the NW at Huanuco, Huanuco, ca. $09^{\circ} 55^{\prime} \mathrm{S} 76^{\circ} 13^{\prime} \mathrm{W}, 16-25$ Oct 1918. CAS 70090, 24, 43.0-85.3 mm SL, CAS 70091, 89, 42.7-94.4 mm SL, Huancachupa creek, a tumultuous small stream from the eastern slope of the central cordillera to río Huallaga a league above Huanuco, ca. 6,000 ft. elev., Huanuco, ca. $09^{\circ} 55^{\prime} \mathrm{S} 7^{\circ} 6^{\circ} 13^{\prime} \mathrm{W}, 16-25$ Oct 1918. CAS 70092, 14, 42.0-73.1 mm SL, large creek/small river arising from río Huallaga above Cayumba rapids, Chumatagua, ca. $09^{\circ} 27^{\prime} \mathrm{S} 75^{\circ} 58^{\prime} \mathrm{W}$, 1 Oct 1918. CAS 70093, 6 of 7, 37.1-84.3 mm SL, Chachara and Ford on lower río Chinchao (into río Huallaga above Cayumba rapids), Pedra Blanca, ca. $09^{\circ} 27^{\prime}$ 'S 755' 'W, 2 Oct 1918. ICNMHN 7317, 73, 32.6-109.9 mm SL, provincia de Leoncio Prado, Parque Nacional Tingo Maria, Huanuco, ca. 09¹8'S 7559'W, May 2003. MUSM 10565, 2 of 3, Huanuco, río Huallaga, río Cayumba, río Marañon drainage, km 495, 09³2'00”S 7600'00”W, 29 Sep 1996. Río Marañon drainage: CAS 44355, 1, $57.9 \mathrm{~mm}$ SL [listed as $H$. helleri by Eigenmann (1927: 406)], río Crisnejas near its junction with upper río Paipay, at Paipay, Cajamarca, ca. $07^{\circ} 25^{\prime}$ 'S $78^{\circ} 10^{\prime} \mathrm{W}$,

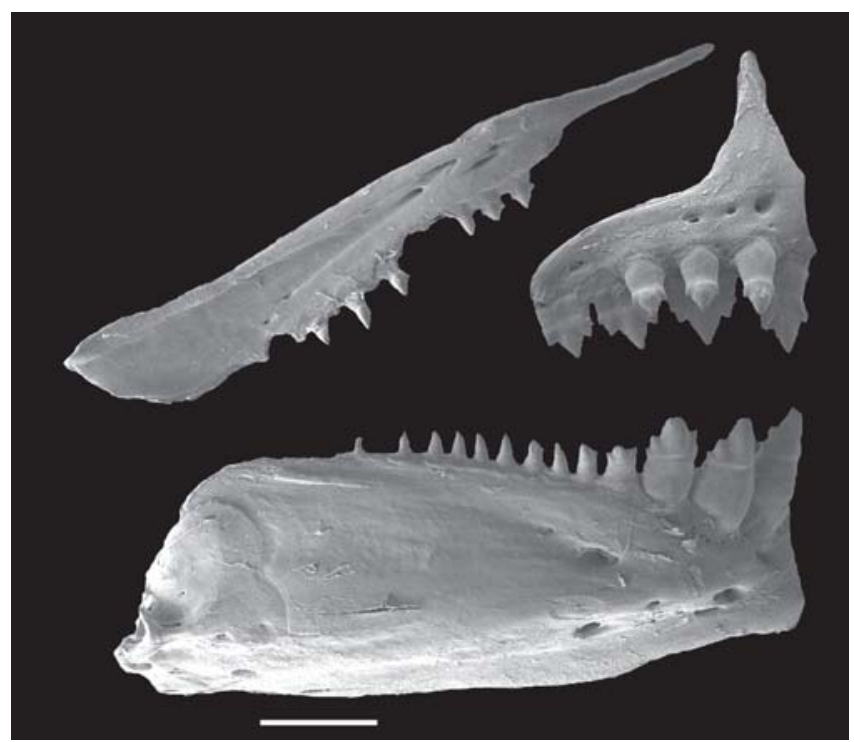

Fig. 9. Hemibrycon huambonicus, ROM 55406, male, $70.0 \mathrm{~mm}$ SL. Scanning electron micrograph of right side upper and lower jaws. Scale bar $=1 \mathrm{~mm}$. 
Aug 1923. CAS 70083, 2, 52.5-53.5 mm SL, on the intercordilleran río Marañon at 3,500 ft. elev., Balsas, Amazonas, ca. 06 $00^{\circ}$ 'S 775'' W, Jul 1923. CAS 70086, 25, 52.6-82.4 mm SL, Cajamarca, río Paipay into río Crisnejas near its junction with upper río Marañon, $c a .07^{\circ} 20^{\prime} \mathrm{S} 77^{\circ} 45^{\prime} \mathrm{W}$, small deeply entrenched stream $c a$. 4,000 ft. elev., Jul 1923. ROM 52238, 40 of 85, 25.6-94.5 mm SL, ca. $74 \mathrm{~km} \mathrm{~W}$ of road going $\mathrm{N}$ to Jean, between Pucara and Guabel, Huancabamba River tributary, río Marañon drainage, $05^{\circ} 56^{\prime} 00^{\prime \prime} \mathrm{S}$ 79¹5'00"W, 8 Jul 1986. ROM 55366, 21 of 47, 24.6-62.1 mm SL, ca. $14 \mathrm{~km} \mathrm{~W}$ of Bagua, Marañon River tributary, $05^{\circ} 41^{\prime} 00^{\prime \prime} \mathrm{S}$ 78039'00”W, 1 Jul 1986. ROM 55406, 60 of 603 (3 c\&s), 35.1$105.6 \mathrm{~mm} \mathrm{SL}, 2 \mathrm{~km} \mathrm{NW}$ from the junction of the road to Chachapoyas and the road to Bagua, Utcubamba River tributary, río Marañon drainage, $06^{\circ} 13^{\prime} 00^{\prime}$ 'S 7754'00”W, 29 Jun 1986.

\section{Hemibrycon inambari, new species Figs. 10-11}

Holotype. MUSM 35491, male, 65.4 mm SL, río Araza, río Inambari basin, upper río Madre de Dios drainage, Sirihua, Camanti, Quispicanchi, Cusco, Peru, 1324'05”'S 7053'57’W, 17 Oct 2005, M. Hidalgo.

Paratypes. Peru, Cusco, upper río Madre de Dios drainage, río Alto Madre de Dios: ANSP 143290, 12 (3 c\&s), 26.4-39.0 mm SL; ANSP 143293, 10, 24.1-34.0 mm SL; ANSP 143307, 6, 25.4-35.2 mm SL, río Pilcopata, wire ferry, 3 km above Pilcopata, 12 53 '30"S 71²4’00"W, 16 Jul 1977, R. Horwitz. ANSP 143291, 1, 37.2 mm SL, río Hospital, moderate stream, $2 \mathrm{~km} \mathrm{~W}$ of Patria on N/S road,

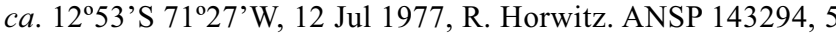
(x-ray), 28.0-76.0 mm SL; ANSP 143300, 2, 38.5-79.3 mm SL; ANSP 143306, 5, 34.0-81.5 mm SL; ANSP 143312, 10 (x-ray), 28.2-48.2 mm SL; ANSP 143317, 5, 28.0-76.0 mm SL, second stream W of end of dirt track off km 143.9 on Huacarpay-Shintuya road, near Patria, Asunción, Cusco, Peru, ca. 12 $2^{\circ} 57^{\prime}$ S $71^{\circ} 25^{\prime} \mathrm{W}, 6-7$ Jul 1977, R. Horwitz. ANSP 151478, 1, 35.0 mm SL; ANSP 151497, 4, 28.8-68.7 mm SL, second stream W of end of dirt track off $\mathrm{km}$ 143.9 on Huacarpay-Shintuya road, near Patria, Asunción, $12^{\circ} 57^{\prime} 30^{\prime \prime} \mathrm{S} 71^{\circ} 21^{\prime} 30^{\prime \prime W}, 5-10 \mathrm{Jul} 1977$, R. Horwitz. ANSP 151526, 2, 34.1-37.2 $\mathrm{mm} \mathrm{SL}$, río Pilcopata, wire ferry, $3 \mathrm{~km}$ above of Pilcopata, ca. $12^{\circ} 56^{\prime}$ S $71^{\circ} 24^{\prime} \mathrm{W}, 16-17$ Jun 1977, R. Horwitz. Río Inambari drainage: ANSP 180770,3 of $4(1 \mathrm{c} \& \mathrm{~s}), 57.1-71.9 \mathrm{~mm}$ SL, tributary of río Araza, vicinity of Quince Mil, $13^{\circ} 18^{\prime} 52^{\prime \prime S}$ 7049'13'W, 25 Jul 2004, M. Sabaj et al. MUSM 26299, 15 of 40, 48.2-87.3 mm SL, MCP 45753, 5, 63.5-82.0 mm SL, collected with the holotype. MUSM 26776, 4 of 8, 43.4-70.9 mm SL, río Araza, San Lorenzo, Camanti, Quispicanchi, Cusco, 13¹3'5'S 70³1'39'W, 25 Oct 2005, M. Hidalgo. MUSM 26802, 15 of 97, 28.3-51.1 mm SL, UFRGS 13201, 5, 46.4-50.1 mm SL, quebrada Huaca, Huañuna, Ayapata, Carabaya, Puno, 13²'16”'S 70²2'26”W, 25 Oct 2005, M. Hidalgo.

Diagnosis. Hemibrycon inambari is distinguished from most of its congeners by the number of lateral line scales (41-44 vs. $39-41$ or $44-58$, Fig. 3). From the species sharing similar lateral line counts, it differs from $H$. boquiae, $H$. metae, $H$. polyodon, and $H$. taeniurus by the number of scales along anal-fin base scale sheath (6-10 vs. 10-24); from $H$. jabonero by the number of gill rakers (17-18 vs. 19-21); from $H$. brevispini by the number of cusps of three anteriormost dentary teeth ( $5 v s .3)$, and by absence of bony hooks in the caudal-fin rays of males ( $v s$. presence); from $H$. divisorensis and $H$. surinamensis by the absence of a wide black asymmetrical spot covering base of caudal-fin rays; from $H$. helleri and $H$. jelskii by the size of humeral spot (over 7-8 vs. 5-6 horizontal series of scales, and from $H$. helleri by the number of predorsal scales (13-16 vs. 16-18), and by the total number of vertebrae (41-43 vs. 39-40); from $H$. mikrostiktos by the size of humeral spot (6-7 vs. 2-3 horizontal series of scales), and by total number of pelvic-fin rays (7 vs. 8); from $H$. paez, $H$. quindos, and $H$. virolinica by the number of cusps of premaxillary inner row teeth (5-7 vs. 34 ); from $H$. rafaelense and $H$. raqueliae by the number of predorsal scales (13-16 vs. 10-12 and 10-13); from H. raqueliae by the number of cusps of first maxillary tooth (3vs. 5).

Description. Morphometric data for Hemibrycon inambari summarized in Table 2. Largest male $69.5 \mathrm{~mm}$ SL, largest female $87.3 \mathrm{~mm}$ SL. Body compressed and elongate; greatest body depth at vertical through middle length of pectoral fins. Dorsal profile of head straight to slightly convex. Dorsal body profile convex from occipital bony to base of last dorsal-fin ray; straight from this point to adipose-fin origin. Ventral profile of head nearly straight to slightly convex. Ventral body profile convex from pectoral-fin origin to pelvic-fin origin, and straight to slightly convex to anal-fin origin. Body profile along anal-fin base posterodorsally slanted. Caudal peduncle elongate, nearly straight to slightly concave along dorsal and ventral margins.

Snout rounded from margin of upper lip to vertical through anterior nostrils. Head small. Mouth terminal, mouth slit below at horizontal through middle of eye. Maxilla long and slightly curved, aligned at angle of approximately $45^{\circ}$ to longitudinal body axis.

Premaxilla with two tooth rows; outer row with 3-5, tricuspid teeth with central cusp slightly longer; inner row with 4 penta- to heptacuspids teeth, gradually decreasing in length from first to third teeth and last tooth smallest; central cusp twice or three times longer and broader than other cusps. Maxilla almost fully toothed with 8-14 uni- to tricuspid teeth, with central cusp longer. Three anteriormost dentary teeth larger, with 5 cusps, followed by medium sized tooth with 3 cusps, and 7-9 teeth with 1-3 cusps or conical; central cusp in all teeth two to three times longer and broader than other cusps. Cusp tips slightly curved posteriorly and lingually (Fig. 11).

Dorsal-fin rays ii,8 $(n=80)$; first unbranched ray approximately one-half length of second ray. Dorsal-fin origin located approximately to middle of SL and posterior to vertical through pelvic-fin origin. Profile of distal margin of dorsal fin nearly straight to slightly concave. Males with bony hooks in distal one-third of first branched rays. Adipose-fin located at vertical through insertion of last anal-fin rays. Anal-fin rays iiiv,22-26 (mode $=24, \mathrm{n}=79$, Fig. 2). Anal-fin profile slightly convex to nearly straight both sexes. Anal-fin origin approximately at vertical through insertion in the last dorsal fin rays. Anal-fin rays of males bearing one pair of small bony hooks along posterolateral border of each segment of lepidotrichia, along last unbranched ray and almost all branched rays. Hooks usually located along posteriormost branch and 


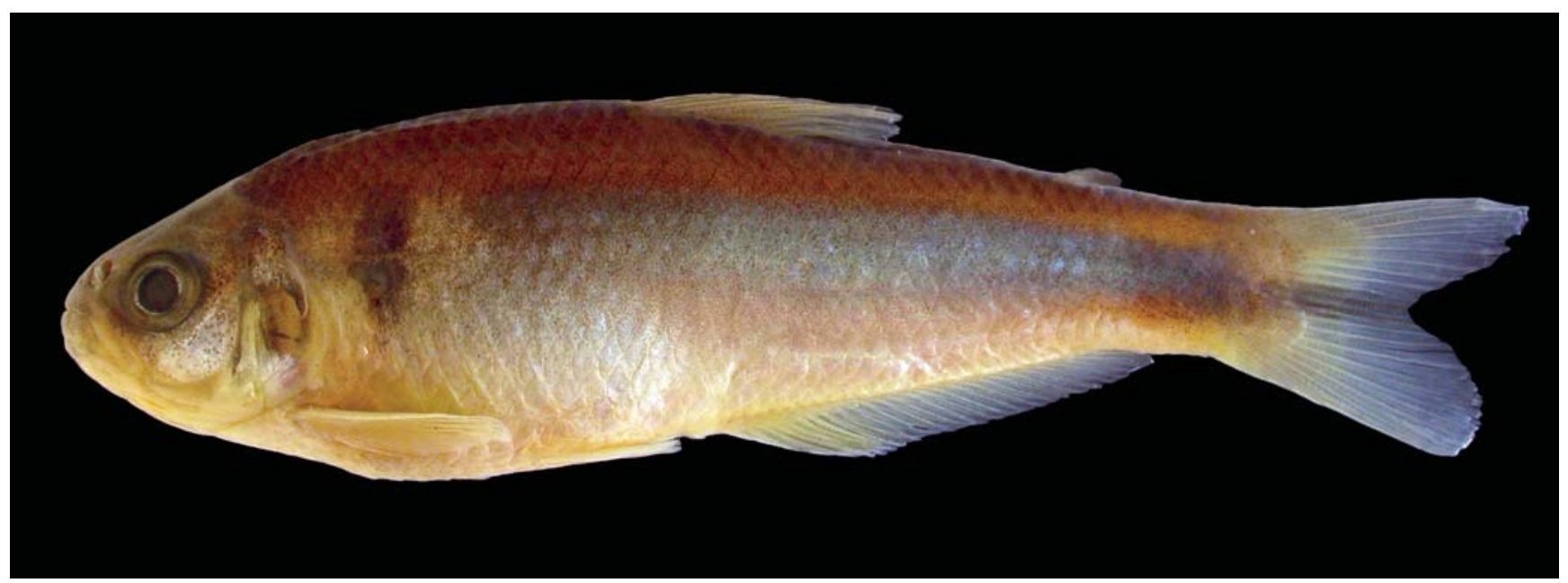

Fig. 10. Hemibrycon inambari, MUSM 35491, holotype, male, 65.4 mm SL, upper río Madre de Dios basin, Peru.

distal $1 / 2$ to $2 / 3$ of each ray. Pectoral-fin rays i, 10-12 (mode $=11$, $\mathrm{n}=80$ ). Pectoral-fin tip not reaching pelvic-fin origin in both sexes. Males with bony hooks developed on distal portion of unbranched and all branched rays. Pelvic-fin rays i,6,i or i,7 $(n=79)$. Pelvic-fin origin located 4-5 predorsal scales anterior to vertical through dorsal-fin origin. Pelvic fin of males usually bearing one small bony hook per segment of lepidotrichia along ventromedial border in all branched rays. Caudal fin forked with 19 principal rays without bony hooks $(\mathrm{n}=79)$; lobes similar in size. Caudal-fin base with a few scales in the half of lobes, following by one large and round scale in each lobe. Dorsal procurrent rays 8-10 and ventral procurrent rays 9-10 $(n=12)$.

Scales cycloid, moderately large. Lateral line complete with $41-44$ ( mode $=41, n=71$, Fig. 3). Scale rows between dorsal-fin origin and lateral line $7-8($ mode $=7, n=78)$; scale rows between lateral line and pelvic-fin origin $5-6($ mode $=6, n=78)$. Predorsal

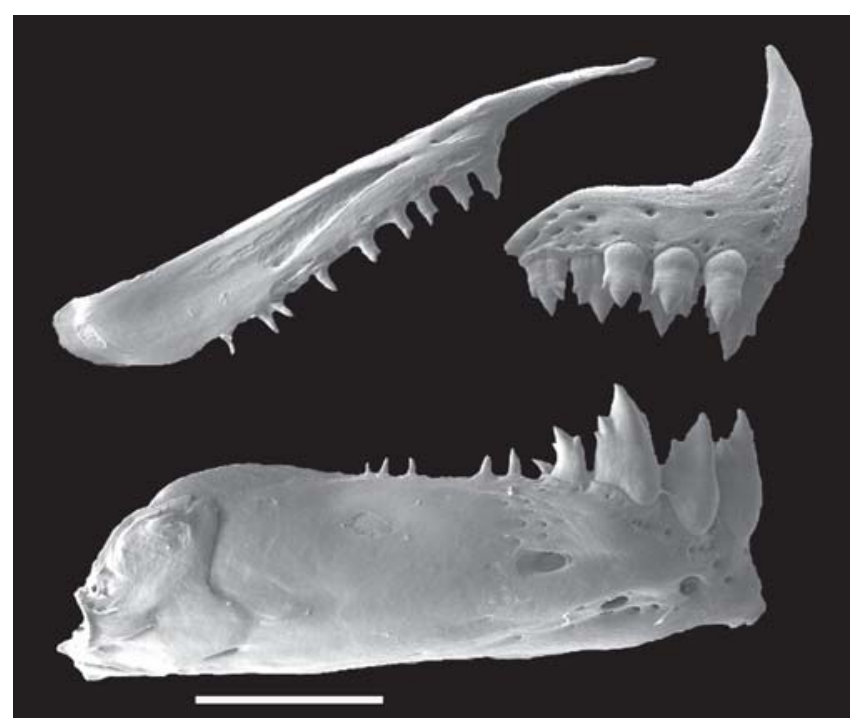

Fig. 11. Hemibrycon inambari, ANSP 143290, paratype, female, $39.2 \mathrm{~mm} \mathrm{SL}$. Scanning electron micrograph of right side upper and lower jaws. Scale bar $=1 \mathrm{~mm}$. scales 13-16, arranged in regular series $(\operatorname{mode}=16, \mathrm{n}=75)$. Scales rows around caudal peduncle $14(\operatorname{mode}=14, \mathrm{n}=70)$. Axillary scale on pelvic-fin origin extends posteriorly covering 2-3 scales. Scale sheath along anal-fin base with 6-10 scales in single series, extending to base of most anterior branched rays.

Precaudal vertebrae 18-19; caudal vertebrae 21-22; total vertebrae 39-40 $(n=17)$. Supraneurals 6-7 $(n=16)$. Gill rakers on upper limb of outer gill arch 6-7, and on lower limb 10-11 $(n=11)$.

Color in alcohol. General ground body color yellowish. Dorsal portion of head and body with dense concentration of black chromatophores. Dorsolateral portion of head and body with scattered black chromatophores. Midlateral body silvery. One large and vertical black humeral spot, located over third to sixth lateral line scales and extending over 5-6 horizontal series of scales, including lateral line. Midlateral dark stripe extending from humeral region to middle caudalfin rays, broad in the caudal peduncle. Abdominal region almost devoid of black chromatophores. Adipose fin densely dark brown pigmented. Dorsal and caudal fin with dark borwn pigmentation diffuse and anal fin with small black chromatophores along its border forming narrow stripe. Pectoral and pelvic fins hyaline (Fig. 10).

Sexual dimorphism. Males of Hemibrycon inambari are easily recognized by the presence of bony hooks on the dorsal-, pectoral-, anal- and pelvic-fin rays. Males and females also slightly differ in pectoral- and pelvic-fin lengths and body depth (Table 2), and in anal-fin shape, slightly concave in males and nearly straight in females. Mature males with gill gland on first gill arch, covering the first branchial filaments.

Distribution. Hemibrycon inambari is known from río Alto Madre de Dios and río Inambari drainages, upper río Madre de Dios drainage, Peru (Fig. 4).

Etymology. The specific name, inambari, is in reference to the type locality, río Inambari. A noun in apposition. 


\section{Hemibrycon jelskii (Steindachner, 1877)} Figs. 12-13

\begin{abstract}
Tetragonopterus jelskii Steindachner, 1877: 40-42 (original description, type locality: Monterico in Peru [Monterrico, Department of Ayacucho, río Ucayali drainage, Peru]). Hemibrycon jelskii. -Eigenmann, 1910: 432 (listed).
\end{abstract}

Diagnosis. Hemibrycon jelskii is distinguished from all congeners, except $H$. helleri, by the size of humeral spot (over 7-9 vs. 3-6 horizontal series of scales). It differs from $H$. helleri by the number of branched anal-fin rays (25-30 vs. 19-23, Fig. 2), and by the number of scales along anal-fin base scale sheath (13-28 vs. 6-12). Hemibrycon jelskii is rather similar to $H$. divisorensis, but can be distinguished by the absence of a wide black asymmetrical spot covering base of caudal-fin rays and black band in the lower half of the caudal peduncle ( $v s$. presence), and by the number of scale rows above and below lateral line (7-9 and 5-7 vs. 6-7 and 4-5, respectively).

Description. Morphometric data for $H$. jelskii summarized in Table 3. Largest male $77.9 \mathrm{~mm}$ SL, largest female $101.7 \mathrm{~mm}$ SL. Body compressed and moderately elongate; greatest body depth at vertical through middle length of pectoral fins. Dorsal profile of head nearly straight to slightly convex, and slightly concave in the occipital region. Dorsal body profile convex from occipital bone to base of last dorsal-fin ray; straight from this point to adipose-fin origin. Ventral profile of head nearly straight to slightly convex. Ventral body profile convex from pectoral-fin origin to pelvic-fin origin and straight to anal-fin origin. Body profile along anal-fin base posterodorsally slanted. Caudal peduncle elongate, nearly straight to slightly concave along dorsal and ventral margins.

Snout rounded from margin of upper lip to vertical through anterior nostrils. Head small. Mouth terminal, mouth slit nearly at horizontal through below middle of eye. Maxilla long and slightly curved, aligned at angle of approximately $45^{\circ}$ to longitudinal body axis, and its posterior tip extending below orbit, reaching nearly to vertical through center of eye.

Premaxilla with two tooth rows; outer row with 3-6, tri- to pentacuspid teeth with central cusp slightly longer; inner row with 4 pentacuspid teeth, gradually decreasing in length from first to third teeth and last tooth smallest; central cusp twice or three times longer and broader than other cusps. Maxilla fully toothed with 8-17 uni- to tricuspid teeth, with central cusp longer. Three anteriormost dentary teeth larger, with 5-7 cusps, followed by medium sized tooth with 3-5 cusps, and 8-10 teeth with 1-3 cusps or conical; central cusp in all teeth two to three times longer and broader than other cusps. Cusp tips slightly curved posteriorly and lingually (Fig. 13).

Dorsal-fin rays ii,8 $(n=224)$; first unbranched ray approximately one-half length of second ray. Dorsal-fin origin located approximately to middle of SL and posterior to vertical through pelvic-fin origin. Males with bony hooks in distal one-third of first branched rays. Profile of distal margin of dorsal fin nearly straight to slightly concave. Adipose-fin located at vertical through insertion of last anal-fin rays. Analfin rays iii-v, 25-30 (mode $=27, \mathrm{n}=224$, Fig. 2$)$. Anal-fin profile slightly concave in males and nearly straight in females. Analfin origin approximately at vertical through insertion in the last dorsal fin rays. Anal-fin rays of males bearing one pair of bony hooks along posterolateral border of each segment of lepidotrichia, along last unbranched ray and all branched rays, usually to fifth branched rays. Hooks usually located along posteriormost branch and distal $1 / 2$ to $2 /{ }_{3}$ of each ray. Pectoralfin rays $\mathrm{i}, 10-13$ ( mode $=11, \mathrm{n}=224)$. Pectoral-fin tip reaching pelvic-fin origin in males. Males with bony hooks on distal portion of unbranched and all branched rays. Pelvic-fin rays $\mathrm{i}, 6, \mathrm{i}$ or i,7 $(\mathrm{n}=224)$. Pelvic-fin origin located 6-7 predorsal scales anterior to vertical through dorsal-fin origin. Pelvic fin of males usually bearing one small bony hook per segment of lepidotrichia along ventromedial border of all branched rays. Caudal fin forked with 19 principal rays $(n=224)$. Caudal-fin base with few scales. Dorsal procurrent rays 10-13 and ventral procurrent rays 10-13 $(\mathrm{n}=16)$.

Scales cycloid, moderately large. Lateral line complete with $40-43$ ( $\operatorname{mode}=41, n=221$, Fig. 3 ). Scale rows between dorsalfin origin and lateral line $7-9(\operatorname{mode}=8, \mathrm{n}=224)$; scale rows between lateral line and pelvic-fin origin 5-7 $($ mode $=6, \mathrm{n}=$ 224). Predorsal scales 13-17, arranged in regular series (mode $=14, \mathrm{n}=218)$. Scales rows around caudal peduncle $16(n=220)$. Axillary scale on pelvic-fin origin extends posteriorly covering 2-3 scales. Scale sheath along anal-fin base with 13-28 scales in single series, extending to base of most branched rays.

Precaudal vertebrae 16-18; caudal vertebrae 21-23; total vertebrae 38-40 $(n=21)$. Supraneurals 6-8 $(n=22)$. Gill rakers on upper limb of outer gill arch 7-9, and on lower limb 12-14 $(n=26)$.

Color in alcohol. General ground body color brown yellowish. Dorsal portion of head and body with concentration of black chromatophores. Dorsolateral portion of head and body with scattered black chromatophores. One vertical black humeral spot, located over fourth to sixth lateral line scales and extending over 7-9 horizontal series of scales, including lateral line. Midlateral stripe silvery. Midlateral dark stripe extending from humeral region to middle caudal-fin rays, broad in the caudal peduncle. Abdominal region almost devoid of black chromatophores. Dorsal and caudal fin with black pigmentation diffuse and anal fin with small black chromatophores along its border forming narrow stripe. Pectoral, pelvic and adipose fins hyaline (Fig. 12).

Sexual dimorphism. Males of Hemibrycon jelskii are easily recognized by the presence of bony hooks in dorsal-, anal-, pelvic- and pectoral-fin rays. Males and females also slightly differ in pectoral- and pelvic-fin lengths and body depth (Table 3 ), and in anal-fin shape, slightly concave in males and nearly straight in females. Mature males with gill gland on first gill arch, covering the first branchial filaments (Fig. 7). 


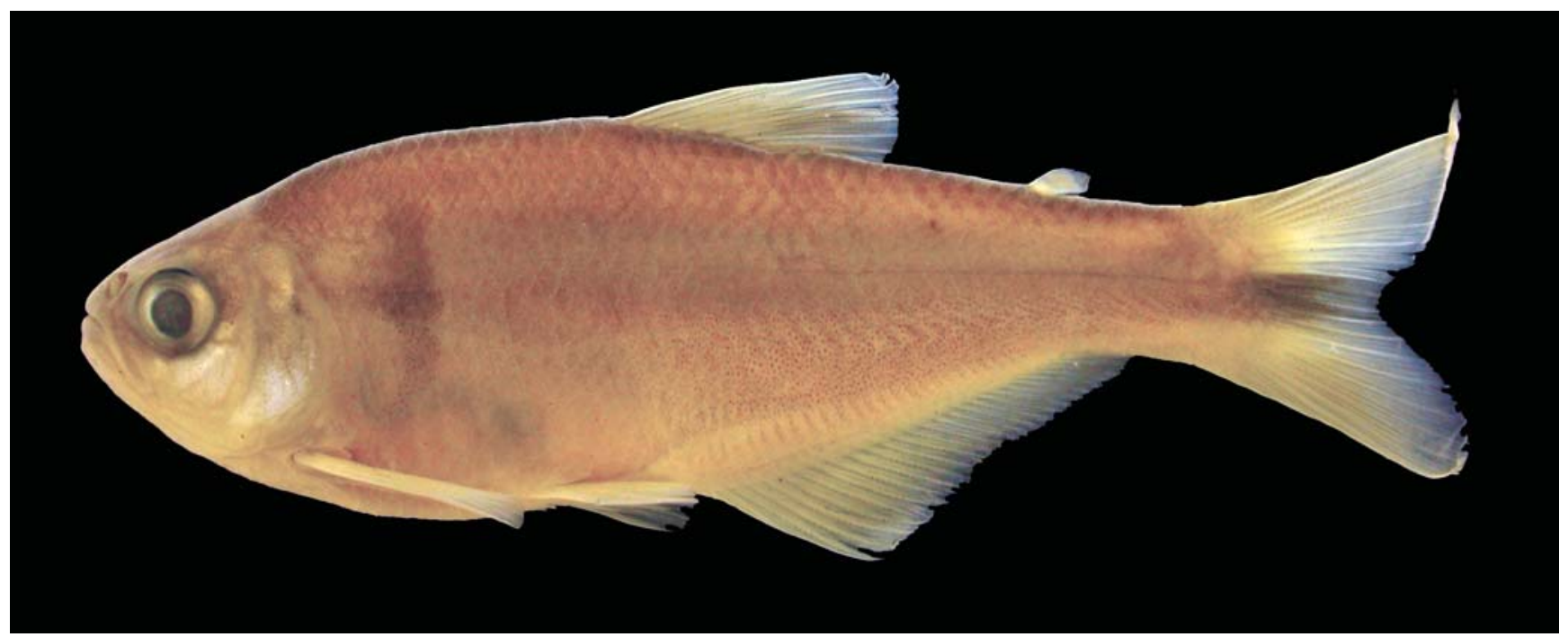

Fig. 12. Hemibrycon jelskii, MUSM 19562, male, $69.0 \mathrm{~mm}$ SL, upper río Ucayali basin, Peru.

Distribution. Hemibrycon jelskii is widespread in the upper portions of río Marañon, río Ucayali, and headwater rivers of río Madeira-Mamoré drainages in Bolivia, Brazil and Peru (Fig. 4).

Remarks. The specimens on which Steindachner (1877: 42) proposed Tetragonopterus jelskii were collected at "Monterico", Peru by Prof. Jeslki. According to Stephens \& Traylor (1983: 137), the exact site of the locality reported by Taczanowski (1884: 73) as "Monterico" has been the subject of differing opinions. Stephens \& Traylor (1983) suggest that the type locality is probably Monterrico $\left(c a .12^{\circ} 28^{\prime} \mathrm{S} 73^{\circ} 54^{\prime} \mathrm{W}\right)$ in the Department of Ayacucho, Peru. The river or basin next this locality is the río Apurimac that belong the río Ucayali drainage, and not río Remac drainage near Lima as reported in Lima et al. (2003: 130). We analyzed eleven specimens of the 22 syntypes deposited in the NMW. The specimens are relatively in good condition and only one specimen examined had the caudal-fin broken.

Geographic variation. Several population samples of $H$.jelskii were examined during this study from upper portions of the río Marañon and río Ucayali drainages, and upper tributaries of the río Madeira-Mamoré drainage. Hemibrycon jelskii possesses a larger number of maxillary teeth (8-17) and scales along anal-fin base scale sheath (13-28), and a larger humeral spot (7-9 horizontal series of scales) among Hemibrycon species.

All these specimens fit within the range of meristic and morphometric data of the syntypes examined, except the orbital diameter. The orbital diameter of syntypes is smaller than that found in all population samples of the species, but this seems to be related to the large body size of the type specimens (Table 3 ). Among 11 syntypes analyzed, nine are larger than $70 \mathrm{~mm}$ SL. No significant differences in counts were found between the examined populations of H. jelskii.
The population from the río Beni has a slightly larger head length and orbital diameter compared with syntypes, but overlapping with the ranges observed in population samples from the río Ucayali, type locality of the species. This difference is due to distinct standard length of specimens between populations. The río Chapare population has a prepectoral distance slightly larger than that observed in the syntypes, but when compared with the río Ucayali population this difference disappear (Table 3).

Material examined. Syntypes. NMW 57548, 2 (x-ray), 99.7101.7 mm SL; NMW 57551, 4 (x-ray), 57.0-68.5 mm SL; NMW 57554,5 (x-ray), 69.4-90.6 mm SL, río Ucayali drainage, $c a$. $12^{\circ} 28^{\prime} \mathrm{S}$ $73^{\circ} 54^{\prime}$ W, Monterrico, Department of Ayacucho, Peru. Non-type specimens. Peru. Río Ucayali drainage: ANSP 143281, 2, 41.9-

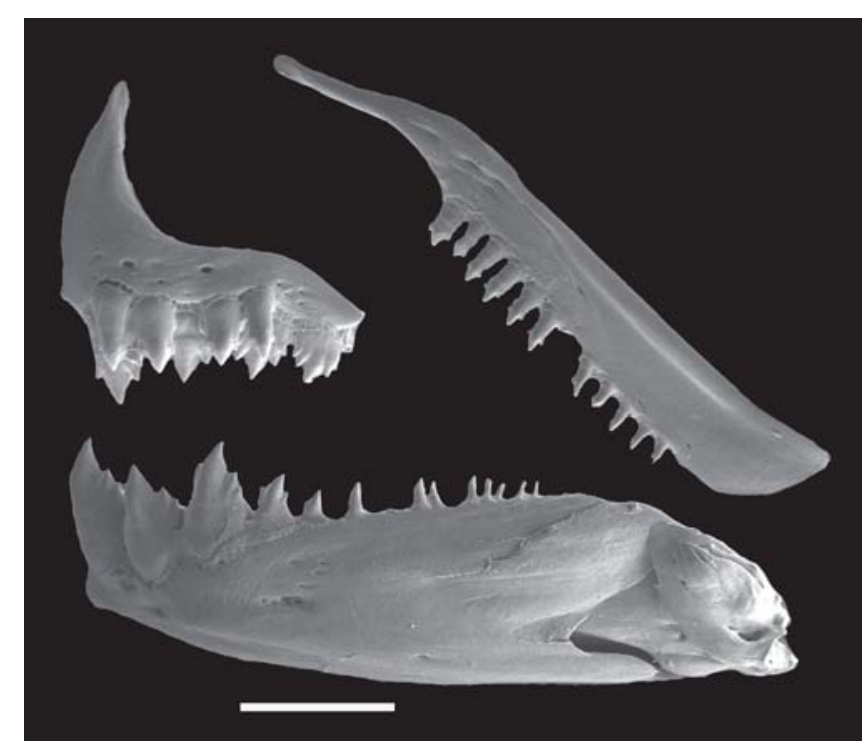

Fig. 13. Hemibrycon jelskii, MUSM 19562, male, 52.1 mm SL. Scanning electron micrograph of left side upper and lower jaws. Scale bar $=1 \mathrm{~mm}$. 
Table 3. Morphometric data of syntypes of Hemibrycon jelskii (NMW 57548, 57551, 57554) and non-types from río Ucayali basin, Peru (A - ANSP180772; MUSM 2958, 17261, 19562; MHNG 218265), from río Chapare basin, Bolivia (B - MCP 35019 , 35020, 35021, 35022; MZUSP 27827; MNHN 1989.1418), from río Madre de Dios basin, Cochabamba, Bolivia (C - MUSM 3759, 11080, 26409, 26785; ROM 66370), from río Huancabamba, río Marañon basin, Peru (D - MUSM 2166; ROM 52240), and from río Beni basin, Bolivia (E - CAS 70081; MNHN 1989.1417). m, males; f, females. SD = Standard deviation.

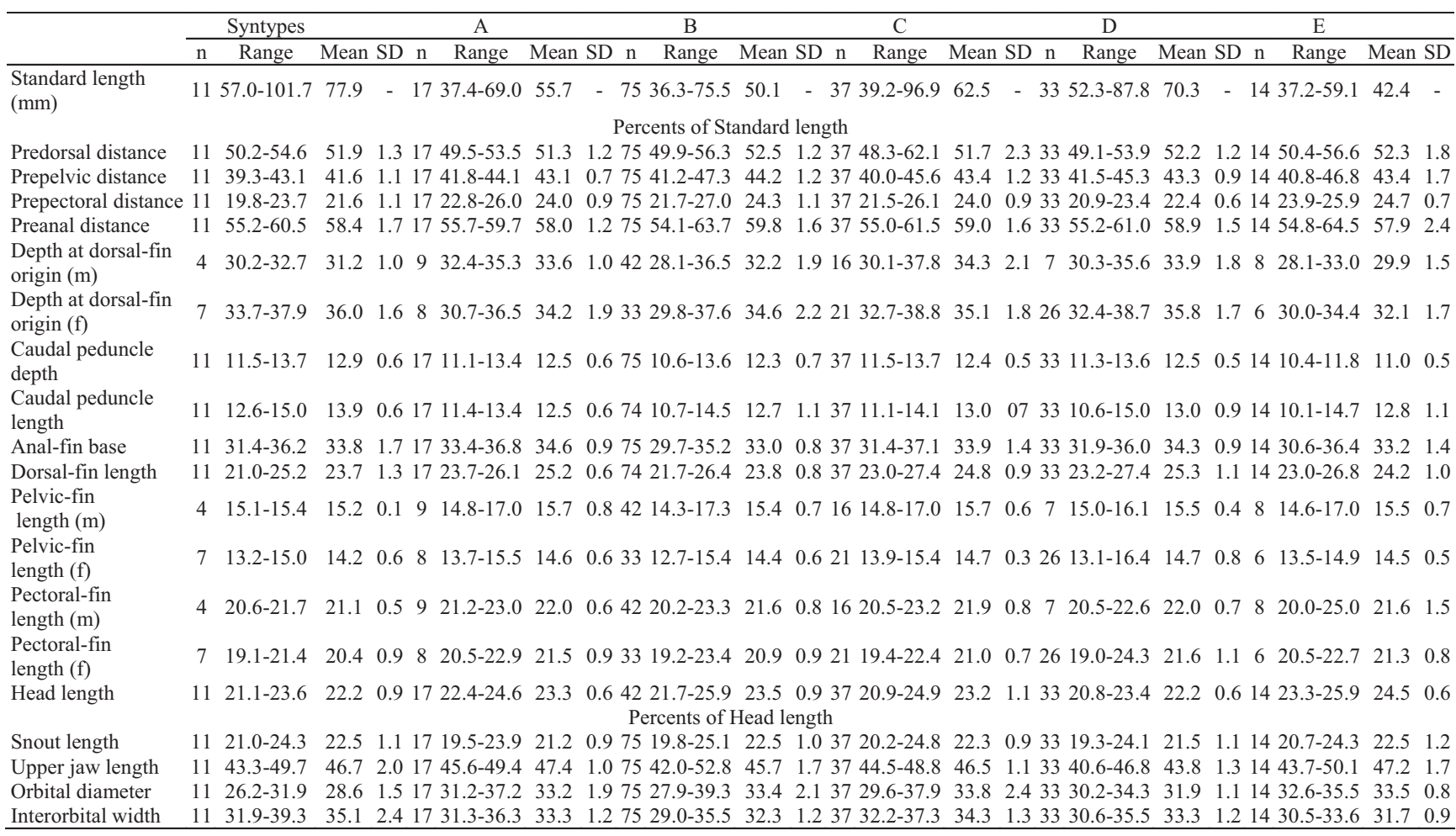

43.5 $\mathrm{mm}$ SL, río Tono at Hacienda San Jorge, $4 \mathrm{~km} \mathrm{~W}$ on road from Patria, Cusco, $c a .12^{\circ} 53^{\prime} \mathrm{S} 71^{\circ} 27^{\prime} \mathrm{W}, 17 \mathrm{Jul} 1977$. ANSP 143282,1 , $32.5 \mathrm{~mm} \mathrm{SL}$, mouth of río Carbon, below Atalaya on N/S road, Cusco-Madre de Dios, ca. $12^{\circ} 53^{\prime}$ 'S $71^{\circ} 20^{\prime} \mathrm{W}, 18$ Jul 1977. ANSP $143285,1,41.3 \mathrm{~mm} \mathrm{SL}$, near Atalaya, N bank tributary of río Carbon ca. $3 \mathrm{~km}$ upstream from Huacarpay-Shintuya Road ford, Madre de Dios-Cusco, ca. $12^{\circ} 54^{\prime}$ 'S $71^{\circ} 21^{\prime}$ 'W, 18 Jul 1977. ANSP 143274, 1, $42.6 \mathrm{~mm}$ SL; ANSP 143286, 1, $79.8 \mathrm{~mm} \mathrm{SL}$; ANSP 143288, 3, 46.8-82.8 mm SL; ANSP 143289, 2, 42-84.4 mm SL, río Hospital ca. $2 \mathrm{~km} \mathrm{~W}$ of Patria on N/S road, Cusco, ca. 12 ${ }^{\circ} 53^{\prime} \mathrm{S}$ $71^{\circ} 20^{\prime} \mathrm{W}, 14-15$ Jul 1977. ANSP 180772, 1, $68.6 \mathrm{~mm}$ SL, río Igoritoshiari, río Urubamba drainage, road crossing north of Kiteni, Cusco, 12²6'56"S 7300'59'W, 21 Jul 2004. MUSM 2958, 4 of 6, 52.6-63.8 mm SL, río Huacamayo, Aguaytía, Padre Abad, Ucayali, ca. $09^{\circ} 02^{\prime} \mathrm{S} 75^{\circ} 30^{\prime} \mathrm{W}, 24$ Nov 1983. MUSM 17261, 20 of 62, 26.5$46.6 \mathrm{~mm}$ SL, río Urubamba, Shepahua, Ucayali, $c a .11^{\circ} 10^{\prime}$ 'S $73^{\circ} 00^{\prime} \mathrm{W}$, 6 Jun 1998. MUSM 19562, 20 of 64, 46.1-69.0 mm SL, middle portion of quebrada John, río Pacuya, Cordilheira Azul Norte, Ucayali, Loreto, ca. $07^{\circ} 20^{\prime} \mathrm{S} 75^{\circ} 40^{\prime} \mathrm{W}, 24$ Aug 2000. Río Marañon drainage: MUSM 2166, 10 of 25, 54.2-81.9 mm SL, tributary of río Huancabamba, between Pucará and Guabel, Jaen, Cajamarca, ca. $05^{\circ} 56^{\prime}$ 'S $79^{\circ} 15^{\prime} \mathrm{W}, 9$ Jul 1986. MUSM 19145, 20 of 70, 38.9-67.9 mm SL, quebrada Chumab, CCNN Paski, río Cenepa, CCA río Marañon, Condarcanqui, Amazonas, 04³3'05”S 78¹1'03”'W, 25 Sep 2001. MUSM 21343, 20 of 82, 33.9-60.4 mm SL, quebrada Capitán Ponce, CCA río Alto Cenepa, Cenepa, Condarcanqui, Amazonas, 034'28'S 78²2'19'W, 15 Nov 2003. ROM 52240, 50 of 205 (3 c\&s), 25.1-87.8 mm SL, ca. $74 \mathrm{~km} \mathrm{~W}$ of road going $\mathrm{N}$ to Jean, between Pucara and Guabel, Huancabamba river tributary, 05 56'00”'S 79¹5'00”W, 8 Jul 1986. Río Madre de Dios drainage: ANSP 143275, 1, $30.0 \mathrm{~mm}$ SL, río Alto Madre de Dios, $c a .15 \mathrm{~km}$ upstream from Boca Manu, Madre de Dios, $c a .12^{\circ} 19^{\prime} \mathrm{S} 70^{\circ} 58^{\prime} \mathrm{W}$. ANSP 143277, 24 (3 c\&s), 22.7-35.8 mm SL, Pilcopata River, wire ferry, $3 \mathrm{~km}$ above Pilcopata, Cusco, 12 $56^{\circ} 30^{\prime \prime} \mathrm{S} 71^{\circ} 24^{\prime} 00^{\prime \prime} \mathrm{W}, 16$ Jun 1977. ANSP 143278, 1, $39.4 \mathrm{~mm} \mathrm{SL}$, at Shintuya, río Alto Madre de Dios, Madre de Dios, ca. $12^{\circ} 40^{\prime} \mathrm{S} 71^{\circ} 11^{\prime} \mathrm{W}, 1-3$ Aug 1977. ANSP 180778, 1, $71.3 \mathrm{~mm}$ SL, río Nusiniscato, río Inambari drainage, road crossing between Quince Mil and Pto. Leguia, Cusco, $13^{\circ} 11^{\prime} 17^{\prime \prime} \mathrm{S} 70^{\circ} 34^{\prime} 05^{\prime} \mathrm{W}, 26 \mathrm{Jul} 2004$. ANSP 180779, 3, 38.1-45.0 $\mathrm{mm}$ SL, río Inambari and mouth of quebrada Hondonado, upstream of Puerto Mazuko, Cusco, 1306'23”S 70²4'44”W, 27 Jul 2004. CAS 70386, 11 of $18,70.5-90.4 \mathrm{~mm}$ SL, tributary to río Tambopata at Pampa Grande, ca. 12 mi below San Ignacio, ca. 3,000 ft. elev., Puno, ca. $14^{\circ} 05^{\prime} \mathrm{S} 69^{\circ} 00^{\prime} \mathrm{W}, 5$ Nov 1951 . MUSM 3759,8 of 25 , 43.9-85.0 mm SL, quebrada Culli, upper río Madre de Dios, Erika, Manu, Madre de Dios, $c a .12^{\circ} 10^{\prime} \mathrm{S} 71^{\circ} 00^{\prime} \mathrm{W}, 5$ Sep 1988. MUSM 11080,8 of 11, 36.6-78.6 mm SL, quebrada Ebebahuaeji, río Candamo, Sandia, Puno, 1314'56”S 7000'35”W, 31 Mar 1997. MUSM 24302, 10 of 22, 26.5-37.3 mm SL, río Amiguillos, río Loa Amigos, Manu, Madre de Dios, 12²5'37's 70¹7'33”'W, 18 Jun 2004, M. Hidalgo et al. MUSM 26409, 20 of 66, quebrada Yanamayo, Quincemil, río Araza drainage, Camanti, Quispicanchi, Cusco, $13^{\circ} 16^{\prime} 54^{\prime \prime}$ S 7047'04'W, 21 Oct 2005. MUSM 26776, 2 of 8, 79.6-88.3 mm SL, río Araza drainage, San Lorenzo, Camanti, Quispicanchi, Cusco, 1313'05"S 70³1'39”W, 25 Oct 2005. MUSM 26785, 20 of 53, 36.8-96.9 mm SL, quebrada Ilahuala, río 
Araza drainage, San Lorenzo, Camanti, Quispicanchi, Cusco, $13^{\circ} 13^{\prime} 02$ 'S 70³1'48'W, 25 Oct 2005. ROM 66370, 9, 39.2-57.2 $\mathrm{mm}$ SL, Tambopata-Candamo Reserved Zone, Puno, left bank, large stream, 1321'02'S 69³8'58'W, Tavara River tributary, 17 Aug 1992. Bolivia. Río Beni drainage: CAS 70079, 11, 46.9-82.2 mm SL, río Popoi, a tributary of upper río Beni, Beni, Sep 1921. CAS 70081, 18, 30.3-46.0 mm SL, 30 miles northwest of Rurrenabaque, Tumapasa, La Paz, ca. $14^{\circ} 10^{\prime} \mathrm{S} 67^{\circ} 30^{\prime} \mathrm{W}$, Dec 1921. MNHN 1989.1417, 2, 50.7-59.1 mm SL, río San Juanito, Yacuma, Beni, $c a$. $15^{\circ} 10^{\prime} \mathrm{S} 67^{\circ} 04^{\prime} \mathrm{W}$, Jul 1982. Río Chapare drainage: MCP 35019 , 17, 42.1-66.8 mm SL, arroyo del Hotel el Puente, Villa Tunari, Chapare, Cochabamba, 16 $59^{\circ} 06^{\prime}$ 'S 65'24'45"W, 10 Nov 2003. MCP 35020 4, 37.4-57.7 mm SL, río Espiritu Santo, Villa Tunari, Chapare, Cochabamba, 16 58'20'S 6524'48'W, 14 Sep 2002. MCP 35021, 10, 40.1-63.5 mm SL, río Espirito Santo, Chocolatal, Chapare, Cochabamba, $17^{\circ} 03$ '51'S 6538'50'W, 20 Feb 2003. MCP 35022, 21,36.3-46.0 mm SL, río Chipiriri, Chipiriri, Chapare, Cochabamba, $16^{\circ} 53$ '33”'S 6524'44”'W, 20 Sep 2002. MNHN 1989.1418, 20, 35.3$75.5 \mathrm{~mm}$ SL, río Espirito Santo, Villa Tunari, Cristal Mayu, ca. $17^{\circ} 03^{\prime}$ S 653' 'W, Jun 1983, L. Loubens. MZUSP 27827, 4, 53.7$73.0 \mathrm{~mm}$ SL, río Espirito Santo, Villa Tunari, Cristal Mayu, $c a$. $17^{\circ} 03^{\prime} \mathrm{S} 65^{\circ} 38^{\prime} \mathrm{W}, 24$ Jun 1983 . Brazil, rio Guaporé drainage: MCP 37754, 5, 26.0-36.1 mm SL, affluent of rio Galera, Pontes e Lacerda, Mato Grosso, 14³9'12"S 59²6’46”W, 12 Jul 2004. MCP 38177, 67 (5 c\&s), 18.0-42.4 mm SL, stream Retiro at road BR 174, tributary of rio Guaporé, Nova Lacerda, Mato Grosso, 1448'07'S 59¹9'24”'W, 12 Jul 2004.

\section{Hemibrycon metae Myers, 1930} Figs. 14-15

Hemibrycon metae Myers, 1930: 68-69 (original description; diagnosis; type locality: Guaiacaramo, río Guavio, Colombia).

Hemibrycon dentatus metae. -Schultz, 1944: 362-363 (table 27 ; in key; new subspecies; non-type material examined).

Diagnosis. Hemibrycon metae is distinguished from most of its congeners by the number of branched anal-fin rays (25-31 vs. 15-24, Fig. 2). From the species sharing similar branched anal-fin rays counts, it differs from $H$. boquiae by the number of caudal peduncle scales (16 vs. 14), and by the number of cusps of second tooth of premaxillary inner row teeth (7vs. $5)$; from $H$. brevispini by the number of cusps of three anteriormost dentary teeth (5vs. 3), and by absence of bony hooks in the caudal-fin rays ( $v s$. presence); from $H$. cairoense by the number of lateral line scales (40-43 vs. 43-46), and by the number of cups of first dentary teeth (5vs. 3); from $H$. dariensis by the absence of pigment in the distal tip of rays just above and below to middle caudal-fin rays; from $H$. dentatus, and $H$. huambonicus by the number of lateral line scales (40-43vs. 44-50); from $H$. divisorensis and $H$. surinamensis by the absence of a wide black asymmetrical spot covering base of caudal-fin rays; from $H$. inambari by the of gill rakers (19-21 vs. 16-18) and by the number of scales along anal-fin base scale sheath (10-19 vs. 6-10); from $H$. jabonero by the number of caudal peduncle scales (16 vs. 14), and the number of scale rows below lateral line (5-7 vs. 45); from $H$. jelskii by the size of humeral spot (5-6 vs. 7-9 horizontal series of scales); from $H$. polyodon by the number of cusps of second tooth of premaxillary inner row teeth (7vs.5), caudal peduncle length (11.1-14.8vs. 14.4-16.6\% SL), and head length (22.1-25.0 vs. 20.9-22.9\% SL); from $H$. quindos by the number of cusps of premaxillary inner row teeth (5-7 vs. 34 ); from $H$. raqueliae by the number of predorsal scales (1416 vs. 10-13) and by the number of cusps of first maxillary tooth ( $3 v s .5$ ); and from H. taeniurus by the number of cusps of second tooth of premaxillary inner row teeth (7vs. 5), and by the humeral spot size (5-6 vs. 4-5 horizontal series of scales).

Description. Morphometric data for $H$. metae summarized in Table 4. Largest male $79.7 \mathrm{~mm}$ SL, largest female $93.1 \mathrm{~mm}$ SL. Body compressed and moderately elongate; greatest body depth anterior to dorsal-fin origin. Dorsal profile of head slightly convex. Dorsal body profile convex from occipital bony to base of last dorsal-fin ray; straight from this point to adipose-fin origin. Ventral profile of head slightly convex. Ventral body profile convex from pectoral-fin origin to pelvicfin origin, and straight to slightly convex to anal-fin origin. Body profile along anal-fin base posterodorsally slanted. Caudal peduncle elongate, nearly straight to slightly concave along dorsal and ventral margins.

Snout rounded from margin of upper lip to vertical through anterior nostrils. Head small. Mouth terminal, mouth slit nearly at horizontal through middle of eye. Maxilla long and slightly curved, aligned at angle of approximately $45^{\circ}$ to longitudinal body axis, and its posterior tip extending below orbit, reaching nearly to vertical through center of eye.

Premaxilla with two tooth rows; outer row with 4-5, tri- to pentacuspid teeth with central cusp slightly longer; inner row with 4 penta- to heptacuspids teeth, gradually decreasing in length from first to third teeth and last smaller; central cusp twice or three times longer and broader than other cusps. Maxilla toothed with 6-11 uni- to pentacuspid teeth, with central cusp longer. Three anteriormost dentary teeth larger, with 5 cusps, followed by medium sized tooth with 3-5 cusps, and 8-10 teeth with 1-3 cusps or conical; central cusp in all teeth two to three times longer and broader than other cusps. Cusp tips slightly curved posteriorly and lingually (Fig. 15).

Dorsal-fin rays ii, $8(n=104)$; first unbranched ray approximately one-half length of second ray. Dorsal-fin origin located posterior to middle of SL and posterior to vertical through pelvic-fin origin. Profile of distal margin of dorsal fin nearly straight to slightly concave. Males with bony hooks in distal one-third of first branched rays. Adipose-fin located at vertical through insertion of last anal-fin rays. Anal-fin rays ii-vi,25-30 (one with 24 and two with 31, mode $=28, \mathrm{n}=104$, Fig. 2). Analfin profile slightly concave in males and females. Anal-fin origin approximately at vertical through insertion in the last dorsal fin rays. Anal-fin rays of males bearing one pair of small bony hooks along posterolateral border of each segment of lepidotrichia, along last unbranched ray and eighth to twelfth branched rays. Hooks usually located along posteriormost branch and distal $1 / 2$ to ${ }^{2} / 3$ of each ray. Pectoral-fin rays i, 10-13 $($ mode $=11, \mathrm{n}=104)$. Pectoral-fin tip surpassing pelvic-fin origin 


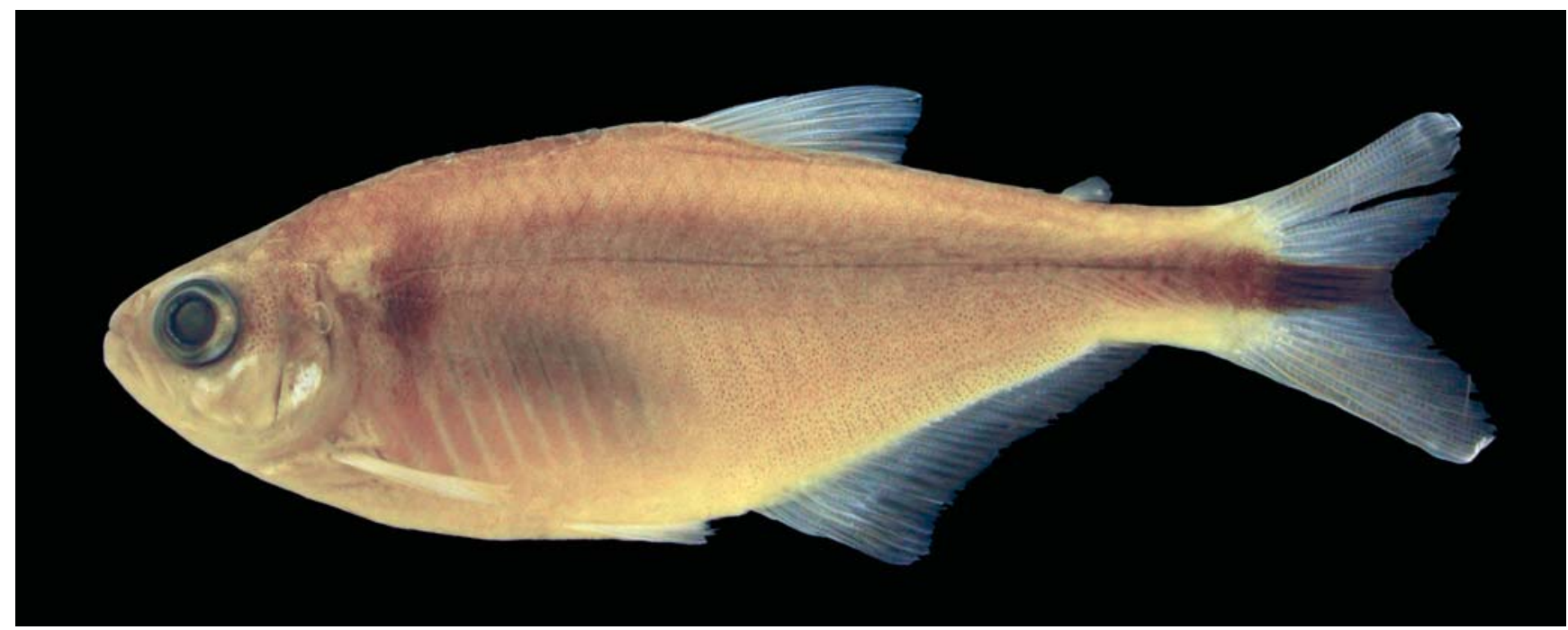

Fig. 14. Hemibrycon metae, INHS 61270, female, 61.4 mm SL, río Apure basin, Venezuela.

in males and nearly reaching in females. Males with bony hooks on distal portion of unbranched and all branched rays. Pelvicfin rays i, $6, i$ (three with i,, , and two with i, $6, n=104$ ). Pelvic-fin origin located 4-5 predorsal scales anterior to vertical through dorsal-fin origin. Pelvic fin of males usually bearing 1 small bony hook per segment of lepidotrichia along ventromedial border of second to eighth branched rays. Caudal fin forked with 19 principal rays without bony hooks $(n=104)$; lobes similar in size. Caudal-fin base have a few scales. Dorsal procurrent rays 11-12 and ventral procurrent rays 10-11 $(n=5)$.

Scales cycloid, moderately large. Lateral line complete with $40-43$ ( mode $=42, n=89$, Fig. 3). Scale rows between dorsal-fin origin and lateral line $7-8($ mode $=8, n=103)$; scale rows between lateral line and pelvic-fin origin 5-6 (rarely 7, mode $=6, \mathrm{n}=103$ ). Predorsal scales 14-16, arranged in regular series (mode $=15, \mathrm{n}=94)$. Scales rows around caudal peduncle $16(n=96)$. Axillary scale on pelvic-fin origin extends posteriorly covering 2-4 scales. Scale sheath along anal-fin base with 10-19 scales in single series, extending to base of most anterior branched rays.

Precaudal vertebrae 17-18; caudal vertebrae 22-24; total vertebrae 39-41 $(n=6)$. Supraneurals 6-8 $(n=6)$. Gill rakers on upper limb of outer gill arch 7-8, and on lower limb 12-13 $(n=19)$.

Color in alcohol. Holotype discolored. General ground body color brown yellowish. Color based on the non-type specimens. General ground body color yellowish. Dorsal portion of head and body with concentration of black chromatophores. Dorsolateral portion of head and body with scattered black chromatophores. One large and vertical black humeral spot, located over third to fifth lateral line scales and extending over 5-6 horizontal series of scales, including lateral line. Midlateral dark stripe extending from humeral region to middle caudal-fin rays, broad in the caudal peduncle. Abdominal region almost devoid of black chromatophores. Dorsal and caudal fin with dark pigmentation diffuse and anal fin with small black chromatophores along its border forming narrow stripe. Pectoral, pelvic and adipose fins hyaline (Fig. 14).
Sexual dimorphism. Males of Hemibrycon metae are easily recognized by the presence of bony hooks on the dorsal-, pectoral-, anal- and pelvic-fin rays. Males and females also slightly differ in pectoral- and pelvic-fin lengths, and body depth (Table 4). Mature males with gill gland on first gill arch, covering the first branchial filaments (Fig. 7).

Distribution. Hemibrycon metae is known from río Orinoco basin, Venezuela and Colombia, and Caribbean coastal basins of Venezuela (Fig. 4).

Remarks. Hemibrycon metae was proposed by Myers (1930) from río Guavio, río Meta drainage, Guaiacaramo, Colombia based only in the holotype. We have compared the populations from río Meta and río Apure, two large rivers from río Orinoco basin, and did not find differences in meristic and morphometric characters.

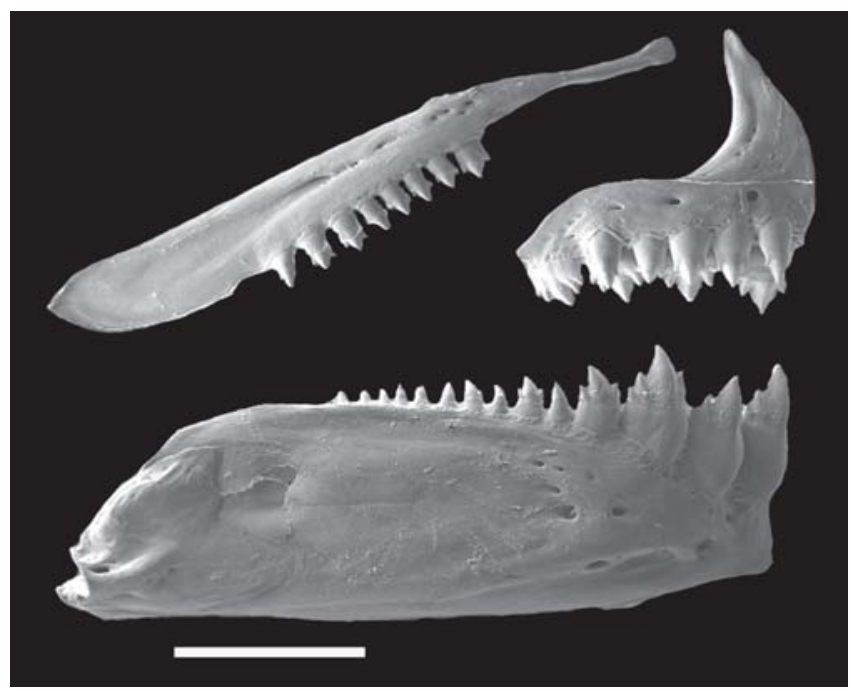

Fig. 15. Hemibrycon metae, MCNG 17030, female, $39.8 \mathrm{~mm}$ SL. Scanning electron micrograph of right side upper and lower jaws. Scale bar $=1 \mathrm{~mm}$. 
In this study some Hemibrycon populations were identified from small coastal river basins in the Golfo de Paria, Venezuela. All these specimens do not exceed $51.3 \mathrm{~mm}$ SL, being smaller than río Orinoco specimens, and difficult to compare regarding body measurements. In relation to scales and maxillary tooth number, this population is more similar to $H$. metae than $H$. taeniurus from Trinidad Island. Samples of large specimens from coastal basins of Venezuela are necessary to confirm whether those populations are indeed conspecific. However, we tentatively assign the examined specimens from that area to H. metae.

Material examined. Holotype. CAS 123727 (ex-SU 23727), female (x-ray), $77.2 \mathrm{~mm} \mathrm{SL}$, at junction of río Guavio and río Upía, río Meta drainage, río Orinoco basin, Guaiacaramo, Colombia, ca. $04^{\circ} 43^{\prime} \mathrm{N} 73^{\circ} 02^{\prime} \mathrm{W}$, Jan 1928 , H. A. Maria. Nontype specimens. Colombia. Meta, río Meta drainage: $\mathrm{IAvH}-\mathrm{P}$ 2973, 7, 53.1-76.0 mm SL, quebrada Palmicha, afluente del río Unete, Casanare, $c a .05^{\circ} 10^{\prime} \mathrm{N} 72^{\circ} 30^{\prime} \mathrm{W}, 1$ Aug 1984. IAvH-P 3122 , 10, 47.6-93.0 mm SL, quebrada Chichaca afluente del río Cachiza, Aguazul, Casanare, ca. $05^{\circ} 15^{\prime} \mathrm{N} 72^{\circ} 29^{\prime} \mathrm{W}, 1$ Mar 1994. IAvH-P 3322, 10, 51.3-70.0 mm SL, quebrada Guamalera, Yopal, Casanare, ca. $05^{\circ} 21^{\prime} \mathrm{N} 72^{\circ} 23^{\prime} \mathrm{W}, 1$ Aug 1993. IAvH-P 3628, 25, 45.0-70.6 mm SL, río Unete, Casanare, ca. $05^{\circ} 10^{\prime} \mathrm{N} 72^{\circ} 30^{\prime} \mathrm{W}, 1$ Aug 1993. IAvH-P 3632, 65, 45.0-86.8 mm SL, ríos Tocaria, Charte and Cravo Sur drainages, ca. $05^{\circ} 20^{\prime} \mathrm{N} 72^{\circ} 20^{\prime} \mathrm{W}, 18$ Aug 1995 . NRM 23991, 1, 48.8 $\mathrm{mm}$ SL, caño Candelaria tributary to río Negro, $c a .20 \mathrm{~km} \mathrm{SW}$ of Villavicencio, ca. $04^{\circ} 5^{\prime} \mathrm{N} 73^{\circ} 42^{\prime} \mathrm{W}$, 10 Jan 1988. NRM 23993, 1, 67.3 $\mathrm{mm}$ SL, caño Union tributary to río Ocoa, where crossed by road Villavicencio - Acacias, $c a$. $04^{\circ} 00^{\prime} \mathrm{N} 73^{\circ} 43^{\prime} \mathrm{W}, 6 \mathrm{Jan} 1988$. Venezuela. Río Orinoco basin, río Apure drainage: INHS 27766, 30 of 51, 29.4-45.8 mm SL, caño Curito at Ruta 5, Barinas, 07 $58^{\prime} 41^{\prime \prime} \mathrm{N}$ $71^{\circ} 00$ ’05”W, 7 Jan 1992. INHS 31851, 12, 27.0-44.5 mm SL, río La Yuca 17 km N Barinas, Barinas, 08 46'00”'N 70¹5'00”'W, 31 Dec 1993. INHS 61270, 22 of 28, 30.7-61.4 mm SL, río Santa Barbara 3 km NE Santa Barbara, Barinas, 0750'14"N 71¹1'14”W, 7 Jan 1992. MCNG 98, 10 of 27, 34.4-43.9 mm SL, $1 \mathrm{~km}$ al S carretera 5, via Cd Bolivia, Barinas, 08²0'8'N 70³1'04'W, 13 Jun 1979. MCNG 5646, 17 of 54, 29.5-47.0 mm SL, río Tucupido en Las Canoas, Portuguesa, $09^{\circ} 03^{\prime} 00^{\prime} \mathrm{N} 70^{\circ} 05^{\prime} 30^{\prime \prime} \mathrm{W}, 18 \mathrm{Mar} 1982$. MCNG 6759, 23 of 73 ( $3 \mathrm{c} \& \mathrm{~s}), 25.5-49.5 \mathrm{~mm}$ SL, río Tinaco, carretera entre Tinaco y Tinaquillo, entre San Carlos e Valencia, Cojedes, Tinaco, $09^{\circ} 48^{\prime} 10^{\prime \prime} \mathrm{N}$ 68²3'50"W, 3 Feb 1982. MCNG 7923, 12 of 64 (2 c\&s), 44.5-71.6 mm SL, caño Grande en Finca Cano Grande, Barinas, Pedraza, 08²4'10”N 70³9'25”'W, 7 Dec 1982. USNM 121466, 18, 35.6-50.5 $\mathrm{mm}$ SL, río Guárico and tributaries between San Sebastian and San Casemiro, Aragua, ca. $09^{\circ} 57^{\prime} \mathrm{N} 67^{\circ} 11^{\prime} \mathrm{W}, 12$ May 1942. USNM 121467, 12 of 117, 42.7-72.8 mm SL, río Torbes, $1 \mathrm{~km}$ above Táriba, Tachira, $c a .07^{\circ} 40^{\prime} \mathrm{N} 72^{\circ} 15^{\prime} \mathrm{W}, 31$ Mar 1942 . Golfo de Paria coastal basin: USNM 228563, 16 of 21, 38.3-52.4 mm SL, Sucre, Clavellino reservoir Sucre, 29 Sep 1979. MCNG 17030, 20 of 58 (3 c\&s), 27.3$49.2 \mathrm{~mm}$ SL, Sucre, Benitez, El Pilar, río Pilar, ca. $10^{\circ} 32^{\prime} \mathrm{N} 63^{\circ} 08^{\prime} \mathrm{W}$, 28 Aug 1984. MCNG 17035, 20 of 76 (3 c\&s), 30.0-46.9 mm SL,

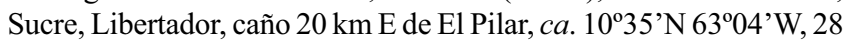
Aug 1984. MCNG 16796, 10 of 19, 30.3-50.2 mm SL, Sucre, Benitez, caño 3 km S de El Pilar, ca. 10³0'N 6307’W, 29 Aug 1984. CAS 70096, 58, 35.0-64.9 mm SL, Miranda, río Tiquirito at Concejo, a tributary of the Tuy River, 1 Aug 1918. FMNH 105860, 52, 21.4$46.7 \mathrm{~mm} \mathrm{SL}$, Venezuela, Monagas, río Azuma at edge of municipio Punceres on road to Caripito, 8 Aug 1985. MNHN 1920.0002, 1, $67.4 \mathrm{~mm} \mathrm{SL}$.

\section{Hemibrycon mikrostiktos, new species Figs. 16-17}

Holotype. MUSM 35490, 44.4 mm SL, río Aguaytía, río Negro, upper río Ucayali basin, Aguaytía, Padre Abad, Ucayali, Peru, 0902'34”S 75³0'45”'W, 2 Nov 1999, P. de Rham \& F. Chang.

Paratypes. MCP 44521, 10 (3 c\&s), 27.6-42.4 mm SL; MUSM 15845,19 measured and counted of 187, 24.5-42.4 mm SL; UFRGS 12003 , 10, 30.9-36.0 mm SL, collected with the holotype.

Diagnosis. Hemibrycon mikrostiktos is readily distinguished from all congeners by the size of the humeral spot (2-3 vs. 4-9 horizontal series of scales), number of scale rows below of the lateral line (3-4 vs. 4-8), and total number of pelvic-fin rays (7 vs. 8). Furthermore, H. mikrostiktos differs from most congeners by the number of branched anal-fin rays (18-21 vs. 21-34, and 17 in H.tridens, Fig. 2), except H. beni and $H$. helleri. It differs from $H$. beni and $H$. helleri by the number of lateral line scales (40-42 vs. 44-53 and 42-44, Fig. 3).

Description. Morphometric data for Hemibrycon mikrostiktos summarized in Table 4. Largest specimen $44.4 \mathrm{~mm}$ SL. Body compressed and moderately elongate; greatest body depth at vertical through middle length of pectoral fins. Dorsal profile of head nearly straight. Dorsal body profile convex from occipital bony to dorsal-fin origin; posteroventrally slanted at dorsal-fin base; straight from last dorsal-fin ray to adiposefin origin. Ventral profile of head convex. Ventral body profile convex from pectoral-fin origin to pelvic-fin origin, and straight to slightly convex to anal-fin origin. Body profile along analfin base posterodorsally slanted. Caudal peduncle short, nearly straight to slightly concave along dorsal and ventral margins.

Snout rounded from margin of upper lip to vertical through anterior nostrils. Head relatively small. Mouth terminal, mouth slit nearly at horizontal through below middle of eye. Maxilla long and slightly curved, aligned at angle of approximately $45^{\circ}$ to longitudinal body axis, and its posterior tip extending below orbit, reaching nearly to vertical through center of eye.

Premaxilla with two tooth rows; outer row with 4-6, tricuspid teeth with central cusp slightly longer; inner row with 4 pentacuspid teeth, gradually decreasing in length from first to third teeth and last tooth smallest; central cusp twice or three times longer and broader than other cusps. Maxilla toothed with 7-11 tri- to pentacuspid teeth, except for last three or four conical teeth, with central cusp longer. Three anteriormost dentary teeth larger, with 5 cusps, followed by medium sized tooth with 3 cusps, and 12-13 teeth with 1-3 cusps or conical; central cusp in all teeth two to three times longer and broader than other cusps. Cusp tips slightly curved posteriorly and lingually (Fig. 17).

Dorsal-fin rays ii, $8(n=20)$; first unbranched ray approximately one-half length of second ray. Dorsal-fin origin located posterior to middle of SL and posterior to vertical through pelvic-fin origin. First dorsal-fin pterygiophore 


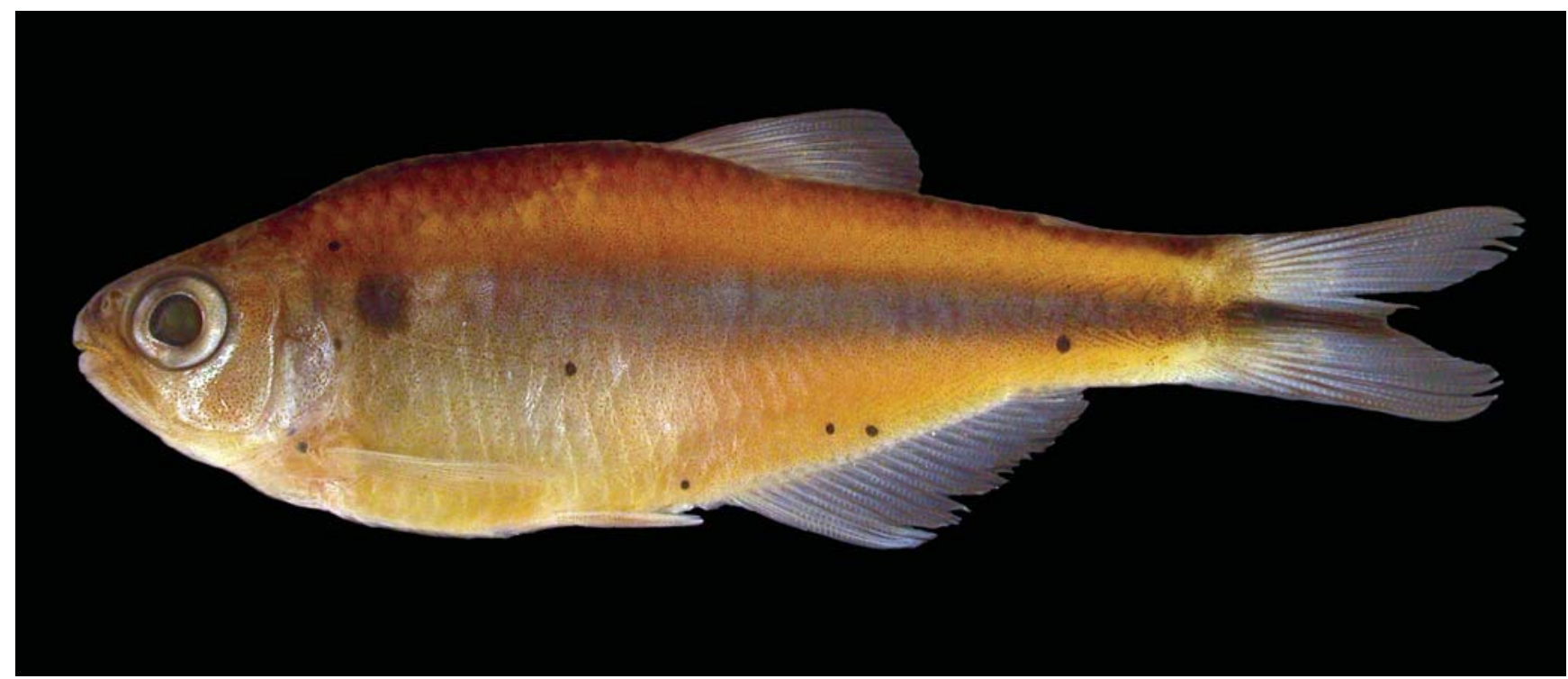

Fig. 16. Hemibrycon mikrostiktos, MUSM 35490, holotype, 44.4 mm SL, upper río Ucayali basin, Peru.

inserted between the neural spines of eleventh to twelfth vertebrae $(n=3)$. Profile of distal margin of dorsal fin convex. Adipose-fin located at vertical through insertion of last or posterior to last anal-fin ray. Anal-fin rays iii-iv, 18-20 (two with 21 , mode $=19, \mathrm{n}=20$, Fig. 2). Anal-fin profile slightly concave in all specimens. First anal-fin pterygiophore inserted between the haemal spine of last precaudal vertebra and the first caudal vertebrae. Anal-fin origin approximately at vertical through insertion in the middle dorsal fin. Pectoral-fin rays i,9-10 $($ mode $=9, n=20)$. Pectoral-fin tip reaching pelvic-fin origin. Pelvic-fin rays i,5,i $(n=15)$ or i,6 $(n=5)$. Pelvic-fin origin located 3-4 predorsal scales anterior to vertical through dorsal-fin origin. Caudal fin forked with 19 principal rays $(\mathrm{n}=$ 20 ); lobes similar in size. Basal portion of caudal-fin lobes covered with irregular scales and smaller than those of the body, following by one larger scale in each lobe. Dorsal procurrent rays 12-13 and ventral procurrent rays 12-14 $(n=3)$.

Scales cycloid, moderately large. Lateral line complete with $40-42$ (mode $=41, n=16$, Fig. 3$)$. [ Scale rows between dorsalfin origin and lateral line $6-7(\operatorname{mode}=6, \mathrm{n}=18)$; scale rows between lateral line and pelvic-fin origin $3-4($ mode $=4, n=$ 18). Predorsal scales 14 , arranged in regular series $(n=18)$. Scales rows around caudal peduncle $14(\mathrm{n}=18)$. Axillary scale on pelvic-fin origin extends posteriorly covering 2-3 scales. Scale sheath along anal-fin base with 7-10 scales in single series, extending to base of most anterior branched rays.

Precaudal vertebrae 17; caudal vertebrae 23-24; total vertebrae 40-41. Supraneurals 6-7 $(n=3)$. Gill rakers on upper limb of outer gill arch 5-6, and on lower limb 9-10 $(n=5)$.

Color in alcohol. Dorsal portion of head and body with dense concentration of black chromatophores. Dorsal and dorsolateral portion of caudal peduncle near caudal fin base densely pigmented. Dorsolateral portion of body with scattered black chromatophores. Snout and upper portion of maxilla densely pigmented. Infraorbitals and opercle with scattered black chromatophores. Midlateral body silvery and dark pigmented. One small black humeral spot, located over third to fourth lateral line scales and extending over 1-2 horizontal series of scales, sometimes including lateral line. Base of caudal fin and middle rays black pigmented. Abdominal region almost devoid of black chromatophores. Dorsal, adipose, anal and caudal fin with dark pigmentation diffuse. Pectoral and pelvic fins hyaline (Fig. 16).

Sexual dimorphism. None of the type specimens examined had hooks on fins or any other apparent sexually dimorphic features. Gill glands were not found on first gill arch.

Distribution. Hemibrycon mikrostiktos is known from río Aguaytía, upper río Ucayali drainage, Ucayali, Peru (Fig. 4).

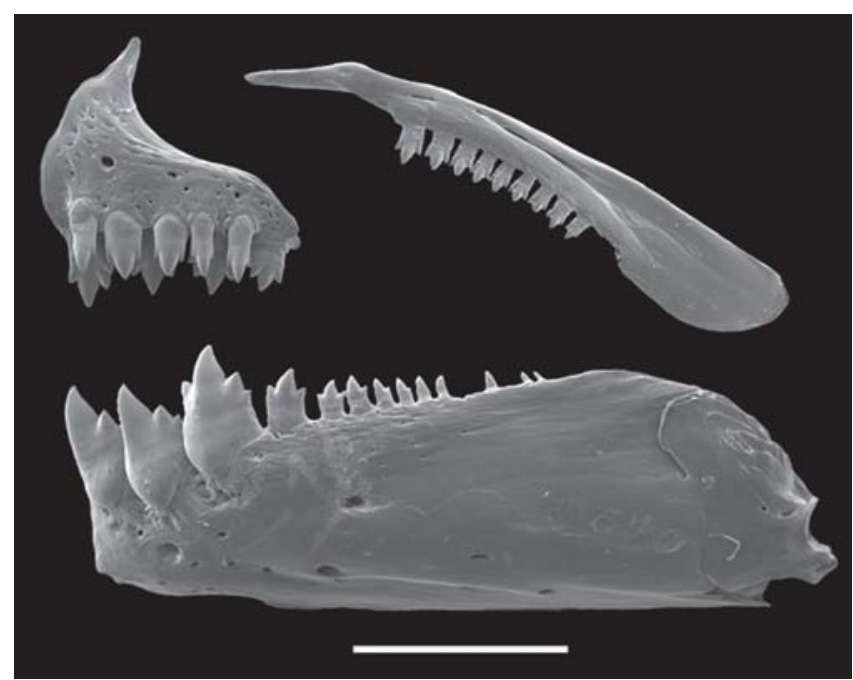

Fig. 17. Hemibrycon mikrostiktos, MCP 44521, paratype, female, $35.7 \mathrm{~mm}$ SL. Scanning electron micrograph of left side upper and lower jaws. Scale bar $=1 \mathrm{~mm}$. 
Table 4. Morphometric data of holotype (H) of Hemibrycon metae (CAS 123727), and non-types from río Meta basin, Colombia (IAvHP2973, 3122, 3322, 3628, 3632), and from río Apure basin, Venezuela (INHS 27766, 31851, 61270; MCNG 98, 5646, 6759, 7923; NRM 23991, 23993), all from río Orinoco basin; and holotype (MUSM 35490) and paratypes (MCP 44521, MUSM 15845, UFRGS 12003, all unsexed) of Hemibrycon mikrostiktos from the upper río Ucayali basin, Peru. m, males; f, females. SD= Standard deviation.

\begin{tabular}{|c|c|c|c|c|c|c|c|c|c|c|c|c|c|c|}
\hline & \multicolumn{9}{|c|}{ H. metae } & \multirow{2}{*}{\multicolumn{5}{|c|}{$\begin{array}{c}\text { H. mikrostiktos } \\
\text { Río Ucayali basin }\end{array}$}} \\
\hline & \multicolumn{6}{|c|}{ Río Meta basin } & \multicolumn{2}{|c|}{ Río Apure basin } & \multirow[b]{2}{*}{ SD } & & & & & \\
\hline & $\mathrm{H}$ & $\mathrm{n}$ & Range & Mean & SD & $\mathrm{n}$ & Range & Mean & & $\mathrm{H}$ & $\mathrm{n}$ & Range & Mean & $\mathrm{SD}$ \\
\hline Standard length (mm) & 77.2 & 43 & $51.3-93.1$ & 67.5 & - & 97 & $32.4-76.7$ & 44.5 & - & 44.4 & 12 & $32.7-44.4$ & 36.8 & - \\
\hline \multicolumn{15}{|c|}{ Percents of Standard length } \\
\hline Predorsal distance & 50.8 & 43 & $47.4-53.3$ & 50.6 & 1.4 & 97 & $48.4-56.2$ & 52.5 & 1.4 & 52.8 & 12 & $52.1-55.2$ & 53.6 & 1.0 \\
\hline Prepelvic distance & 42.2 & 43 & $39.8-45.3$ & 42.0 & 1.3 & 97 & $37.9-49.3$ & 43.9 & 1.5 & 43.9 & 12 & $43.6-45.7$ & 44.8 & 0.7 \\
\hline Prepectoral distance & 22.5 & 43 & $21.0-24.6$ & 22.7 & 0.7 & 97 & $21.7-26.2$ & 23.6 & 0.9 & 23.1 & 12 & $23.1-25.2$ & 24.1 & 0.6 \\
\hline Preanal distance & 58.4 & 43 & $53.3-60.7$ & 57.1 & 1.9 & 97 & $54.7-62.1$ & 58.1 & 1.6 & 58.9 & 12 & $56.5-60.5$ & 59.1 & 1.1 \\
\hline Depth at dorsal-fin origin (m) & - & 19 & $26.4-31.5$ & 29.9 & 1.2 & 27 & $25.6-33.4$ & 28.4 & 1.8 & - & - & - & - & - \\
\hline Depth at dorsal-fin origin (f) & 33.5 & 24 & $29.4-37.0$ & 32.5 & 1.7 & 70 & $25.6-36.5$ & 31.5 & 2.2 & 32.4 & 12 & $30.0-33.6$ & 31.6 & 1.3 \\
\hline Caudal peduncle depth & 12.4 & 43 & $10.6-12.5$ & 11.5 & 0.5 & 97 & $9.5-13.0$ & 10.8 & 0.6 & 12.4 & 12 & $11.0-13.6$ & 12.2 & 0.8 \\
\hline Caudal peduncle length & 13.5 & 43 & $10.7-15.3$ & 13.2 & 1.0 & 97 & $11.1-14.9$ & 12.9 & 0.8 & 15.9 & 12 & $13.6-19.3$ & 16.8 & 1.4 \\
\hline Anal-fin base & 33.2 & 43 & $31.4-37.7$ & 34.6 & 1.3 & 97 & $30.4-36.4$ & 33.2 & 1.1 & 28.2 & 12 & $26.6-30.4$ & 28.0 & 1.1 \\
\hline Dorsal-fin length & 22.6 & 43 & $21.6-26.6$ & 24.0 & 1.1 & 97 & $19.0-27.6$ & 24.0 & 1.1 & 23.4 & 12 & $22.8-25.6$ & 23.7 & 0.7 \\
\hline Pelvic-fin length (m) & - & 19 & $13.4-16.5$ & 14.7 & 0.9 & 27 & $13.0-15.6$ & 14.4 & 0.7 & - & - & - & - & - \\
\hline Pelvic-fin length (f) & 14.0 & 24 & $13.0-15.2$ & 14.1 & 0.6 & 70 & $12.7-16.3$ & 14.1 & 0.7 & 13.6 & 12 & $13.0-14.6$ & 13.8 & 0.5 \\
\hline Pectoral-fin length (m) & - & 19 & $18.8-25.8$ & 21.5 & 1.6 & 27 & $19.5-22.0$ & 21.0 & 0.6 & - & - & - & - & - \\
\hline Pectoral-fin length (f) & 21.2 & 24 & $19.5-23.6$ & 21.1 & 1.0 & 70 & $18.6-22.8$ & 21.3 & 0.8 & 22.1 & 12 & $20.7-23.7$ & 22.1 & 0.7 \\
\hline Head length & 21.4 & 43 & $20.4-23.6$ & 21.6 & 0.7 & 97 & $21.4-25.0$ & 23.2 & 0.8 & 23.8 & 12 & $23.7-25.8$ & 24.8 & 0.7 \\
\hline \multicolumn{15}{|c|}{ Percents of Head length } \\
\hline Snout length & 24.9 & 43 & $20.2-24.4$ & 22.0 & 0.9 & 97 & $18.3-24.3$ & 22.1 & 1.1 & 21.3 & 12 & $19.3-22.9$ & 20.9 & 1.0 \\
\hline Upper jaw length & 45.3 & 43 & $40.9-46.5$ & 43.6 & 1.4 & 96 & $40.8-50.3$ & 45.4 & 1.7 & 50.2 & 12 & $44.5-50.2$ & 47.7 & 1.7 \\
\hline Orbital diameter & 28.7 & 43 & $26.0-34.5$ & 31.1 & 1.8 & 97 & $26.8-38.7$ & 34.2 & 1.8 & 33.2 & 12 & $33.2-37.6$ & 35.7 & 1.1 \\
\hline Interorbital width & 33.1 & 43 & $30.3-35.9$ & 32.7 & 1.2 & 97 & $29.6-34.7$ & 32.4 & 1.1 & 34.1 & 12 & $32.7-35.6$ & 34.1 & 0.8 \\
\hline
\end{tabular}

Etymology. The name mikrostiktos is from the Greek, mickros, small, and stiktos, spot, referring to the small humeral spot. A noun in apposition.

\section{Hemibrycon polyodon (Günther, 1864) Figs. 18-20}

Tetragonopterus (Hemibrycon) polyodon Günther, 1864: 330 (original description; type locality: Guayaquil [río Pastaza basin, río Marañon drainage, upper rio Amazonas basin, Ecuador - see Remarks below]).

Hemibrycon polyodon. Eigenmann, 1909: 313 (listed, Guayaquil). -Román-Valencia et al., 2007: 184 (diagnose and redescription).

Hemibrycon coxeyi Fowler, 1943: 1-3, fig. 1 (original description; holotype: ANSP 70155; type locality: Hacienda Las Mascota, mouth of the río Pastaza, drainage of the Marañon, Ecuador). [NEW SYNONYM]

Hemibrycon pautensis Román-Valencia, Ruiz-C. \& Barriga, 2006: 212 (original description; type locality: río Paute en la desenbocadura del río Namangoza, cuenca del Amazonas, provincia de Morona-Santiago, Ecuador). [NEW SYNONYM]

Diagnosis. Hemibrycon polyodon is distinguished from most of its congeners by the number of branched anal-fin rays (2428 vs. $15-24$ or 28-34, Fig. 2). From the species sharing similar lateral line counts, it differs from $H$. boquiae by the number of scale rows above and below lateral line (8 and 6 vs. 6-7 and 4-5, respectively), and by the number of predorsal scales (15-17 vs. 12-15); from H. brevispini and $H$. cairoense by the number of scale rows above lateral line (8vs. 6-7); from $H$. dariensis, $H$. divisorensis, $H$. surinamensis and $H$. taeniurus by the number of lateral line scales (42-45 vs. 39-42, Fig. 3); from $H$. huambonicus by the number of caudal peduncle scales (16 vs. 18-20), head length (20.9-22.9 vs. 22.0-26.0\% SL), and upper jaw length (43.7-45.6 vs. 45.2-52.6\% HL); from $H$. inambari by the number of scales along anal-fin base scale sheath (14-23 vs. 6$10)$; from $H$.jabonero by the number of caudal peduncle scales (16 vs. 14), and number of scale rows below lateral line (6 vs. 45); from H. jelskii by the number of maxillary teeth (7-10 vs. 817), and by the size of humeral spot (6-7 vs. 7-9 horizontal series of scales); from $H$. metae by the number of cusps of second tooth of premaxillary inner row teeth (5vs. 7), caudal peduncle length (14.4-16.6 vs. 11.1-14.8\% SL), and head length (20.9-22.9 vs. $22.1-25.0 \% \mathrm{SL}$ ); from $H$. quindos by the number of scale rows above and below of lateral line (8 and $6 v s .6-7$ and 4-5); from $H$. rafaelense by the number of predorsal scales $(15-17 v s$. 10-13), orbital diameter (29.5-34.1 vs. 36.6-43.6\% HL), and interorbital width (32.1-35.3 vs. 34.7-41.5\% HL); and from $H$. raqueliae and $H$. yacopiae by the number of predorsal scales (15-17 vs. 10-14), and by the number of cusps of first maxillary tooth ( 3 vs. 5 in H. raqueliae). Furthermore, H. polyodon can be distinguished from $H$. surinamensis and $H$. divisorensis by the absence of a wide black asymmetrical spot covering base of caudal-fin rays, and from $H$. dariensis by the absence of pigment in the distal tip of rays just above and below to middle caudal-fin rays.

Description. Morphometric data for $H$. polyodon summarized in Table 5. Largest male $74.9 \mathrm{~mm}$ SL, largest female $69.5 \mathrm{~mm}$ SL. Body compressed and moderate elongate; greatest body 


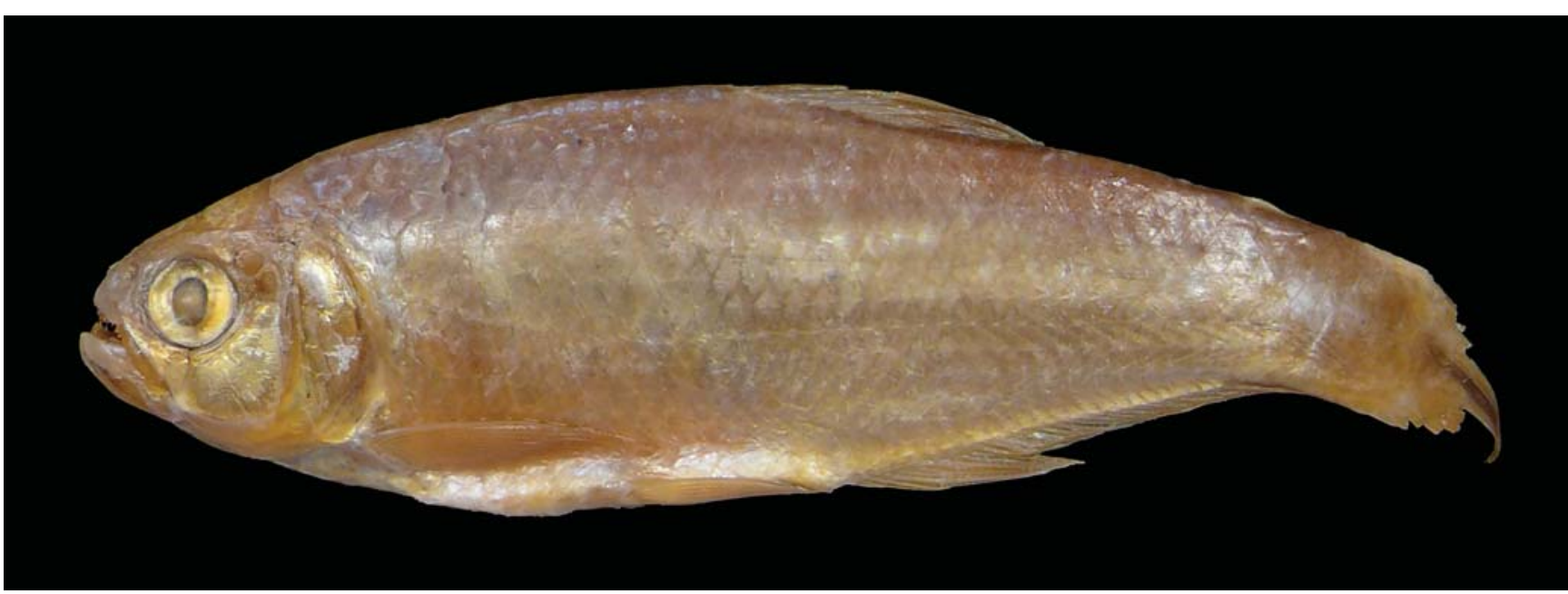

Fig. 18. Hemibrycon polyodon, BMNH 1858.7.25.41, holotype, female, 70.4 mm SL, Guayaquil, Ecuador.

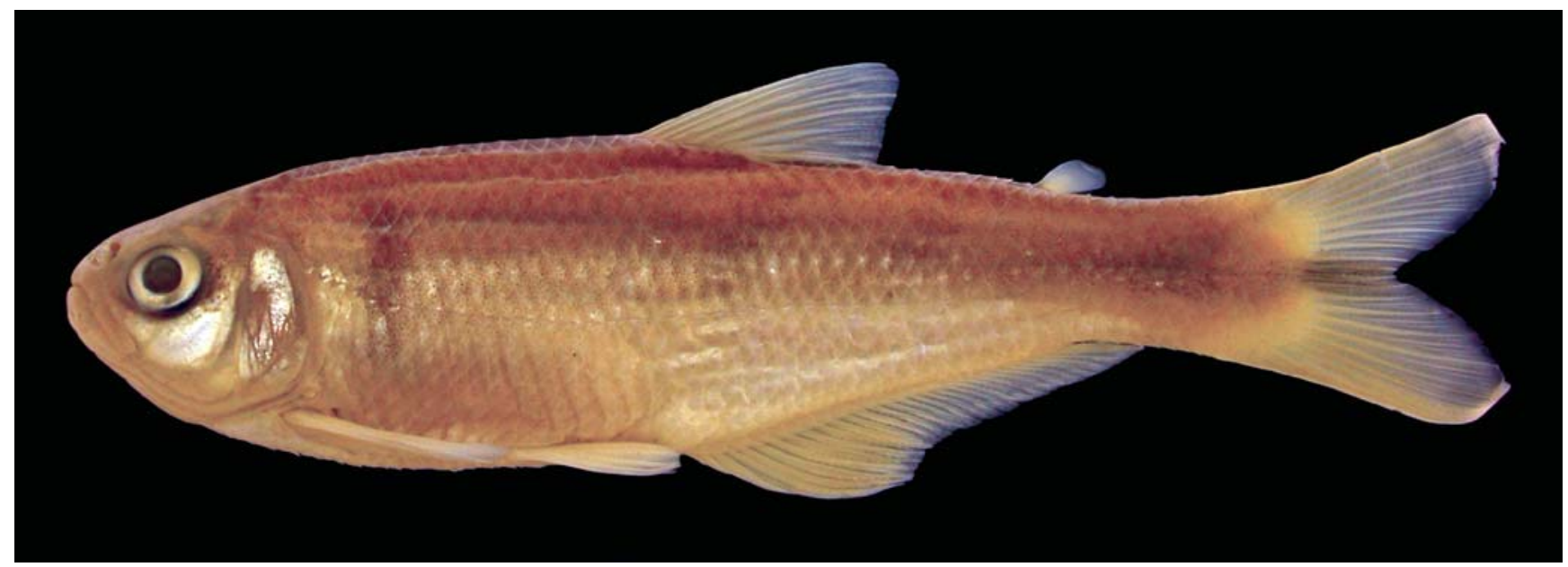

Fig. 19. Hemibrycon polyodon, KU 20004, male, 71.2 mm SL, río Pastaza basin, Ecuador.

depth at vertical through middle length of pectoral fins. Dorsal profile of head slightly convex. Dorsal body profile convex from occipital bony to base of last dorsal-fin ray; straight from this point to adipose-fin origin. Ventral profile of head nearly straight to slightly convex. Ventral body profile convex from pectoral-fin origin to pelvic-fin origin, and straight to anal-fin origin. Body profile along anal-fin base posterodorsally slanted. Caudal peduncle elongate, nearly straight to slightly concave along dorsal and ventral margins.

Snout rounded from margin of upper lip to vertical through anterior nostrils. Head small. Mouth terminal, mouth slit nearly at horizontal through middle of eye. Maxilla long and slightly curved, aligned at angle of approximately $45^{\circ}$ to longitudinal body axis, and its posterior tip extending below orbit, reaching nearly to vertical through center of eye.

Premaxilla with two tooth rows; outer row with 3-5, tricuspid teeth with central cusp slightly longer; inner row with 4 tri- to pentacuspids teeth, gradually decreasing in length from first to third teeth and last tooth smallest; central cusp twice or three times longer and broader than other cusps. Maxilla fully

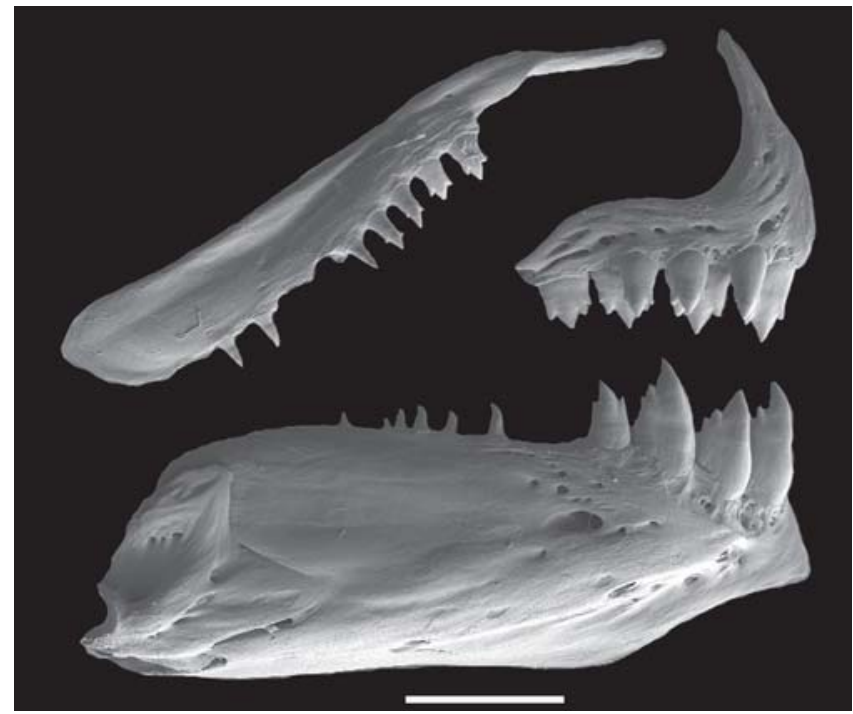

Fig. 20. Hemibrycon polyodon, KU 20004, female, 52.5 mm SL. Scale bar $=1 \mathrm{~mm}$. 
Table 5. Morphometric data of holotype (H) of Hemibrycon polyodon (BMNH 1858.7.25.41) from Guayaquil, Ecuador, and non-types from tributary of río Pastaza, río Marañon basin (KU 19978, 19992, 20004), and of holotype of Hemibrycon tridens (CAS 44358) from rio Apurimac, upper río Ucayali basin, Curuhuasi, Peru. m, males; f, females. $\mathrm{SD}=$ Standard deviation.

\begin{tabular}{|c|c|c|c|c|c|c|}
\hline & \multicolumn{5}{|c|}{ H. polyodon } & H. tridens \\
\hline & \multicolumn{6}{|c|}{ Non-types } \\
\hline & $\mathrm{H}$ & $\mathrm{n}$ & Range & Mean & SD & $\mathrm{H}$ \\
\hline Standard length $(\mathrm{mm})$ & 69.5 & 7 & $45.7-78.3$ & 64.1 & - & 51.5 \\
\hline \multicolumn{7}{|c|}{ Percents of Standard length } \\
\hline Predorsal distance & 51.5 & 7 & $49.5-51.5$ & 50.6 & 0.8 & 49.9 \\
\hline Prepelvic distance & 40.6 & 7 & $39.9-41.9$ & 40.7 & 0.8 & 39.5 \\
\hline Prepectoral distance & 23.5 & 7 & $21.0-23.5$ & 22.2 & 0.6 & 22.3 \\
\hline Preanal distance & 55.7 & 7 & $53.7-58.0$ & 55.7 & 1.9 & 57.0 \\
\hline $\begin{array}{l}\text { Depth at dorsal-fin } \\
\text { origin }(m)\end{array}$ & - & 4 & $27.7-33.8$ & 30.1 & 2.6 & 23.6 \\
\hline $\begin{array}{l}\text { Depth at dorsal-fin } \\
\text { origin (f) }\end{array}$ & 30.6 & 3 & $26.0-30.6$ & 28.3 & 1.7 & - \\
\hline Caudal peduncle depth & 11.7 & 7 & $11.0-12.9$ & 11.6 & 0.7 & 7.7 \\
\hline Caudal peduncle length & 16.1 & 7 & $14.4-16.6$ & 15.5 & 1.0 & 19.1 \\
\hline Anal-fin base & 29.3 & 7 & 29.3-35.9 & 32.8 & 2.0 & 23.7 \\
\hline Dorsal-fin length & 22.3 & 7 & $21.7-24.9$ & 22.9 & 1.3 & 23.7 \\
\hline Pelvic-fin length (m) & - & 4 & $13.1-15.5$ & 14.7 & 1.0 & 18.2 \\
\hline Pelvic-fin length (f) & 14.7 & 3 & $13.2-14.7$ & 13.7 & 0.6 & - \\
\hline Pectoral-fin length (m) & - & 4 & $19.9-21.3$ & 20.6 & 0.7 & 21.7 \\
\hline Pectoral-fin length (f) & 21.2 & 3 & $19.0-21.2$ & 20.3 & 1.2 & - \\
\hline Head length & 22.2 & 7 & $20.9-22.9$ & 21.8 & 0.8 & 23.4 \\
\hline \multicolumn{7}{|c|}{ Percents of Head length } \\
\hline Snout length & 22.5 & 7 & $20.7-23.5$ & 22.0 & 1.0 & 22.0 \\
\hline Upper jaw length & 45.4 & 7 & $43.7-45.6$ & 44.6 & 0.8 & 44.4 \\
\hline Orbital diameter & 33.2 & 7 & $29.5-34.1$ & 32.0 & 1.8 & 33.6 \\
\hline Interorbital width & 32.1 & 7 & $32.1-35.3$ & 33.9 & 0.9 & 28.6 \\
\hline
\end{tabular}

toothed with 7-10 uni- to tricuspid teeth, with central cusp longer. Three anteriormost dentary teeth larger, with 5 cusps, followed by medium sized tooth with 3-5 cusps, and 7-9 teeth with 1-3 cusps or conical; central cusp in all teeth two to three times longer and broader than other cusps. Cusp tips slightly curved posteriorly and lingually (Fig. 20).

Dorsal-fin rays ii,8 $(\mathrm{n}=15)$; first unbranched ray approximately one-half length of second ray. Dorsal-fin origin located approximately to middle of SL and posterior to vertical through pelvic-fin origin. Profile of distal margin of dorsal fin nearly straight. Males with bony hooks in distal one-third of first to fifth branched rays. Adipose-fin located at vertical through insertion of two last anal-fin rays. Anal-fin rays iiiv,24-28 (one with 24 and one with 28, mode $=26, n=14$, Fig. 2). Anal-fin profile convex in males and nearly straight in females. Anal-fin origin approximately at vertical through middle dorsal-fin base. Anal-fin rays of males bearing one pair of developed bony hooks along posterolateral border of each segment of lepidotrichia, along last unbranched ray and all branched rays. Hooks usually located along posteriormost branch and distal $1 / 2$ to $2 / 3$ of each ray. Pectoral-fin rays i, 10-12 (mode $=11, \mathrm{n}=15$ ). Pectoral-fin tip reaching pelvic-fin origin in males. Males with bony hooks on distal portion of unbranched and all branched rays. Pelvic-fin rays i,6,i $(\mathrm{n}=$ 15). Pelvic-fin origin located 5-6 predorsal scales anterior to vertical through dorsal-fin origin. Pelvic fin of males usually bearing one developed bony hook per segment of lepidotrichia along ventromedial border of all branched rays. Caudal fin forked with 19 principal rays without bony hooks $(n=15)$; lobes similar in size. Caudal-fin base with few scales. Dorsal procurrent rays 12 and ventral procurrent rays $11(\mathrm{n}=2)$.

Scales cycloid, moderately large. Lateral line complete with $42-45$ ( mode $=45, n=14$, Fig. 3 ). Scale rows between dorsalfin origin and lateral line $8(n=15)$; scale rows between lateral line and pelvic-fin origin $6(n=15)$. Predorsal scales $15-17$, arranged in regular series $($ mode $=16, \mathrm{n}=13)$. Scales rows around caudal peduncle $16(\mathrm{n}=14)$. Axillary scale on pelvicfin origin extends posteriorly covering $2-3$ scales. Scale sheath along anal-fin base with 14-23 scales in single series, extending to base of $15^{\text {th }}$ to $24^{\text {th }}$ branched rays.

Precaudal vertebrae 18-19; caudal vertebrae 22-24; total vertebrae 40-43. Supraneurals 7-9. Gill rakers on upper limb of outer gill arch 7-8, and on lower limb 11-13 $(n=5)$.

Color in alcohol. The holotype is discolored, except for the middle caudal-fin rays (Fig. 18). Color based on the non-type specimens. General ground body color yellowish. Dorsal portion of head and body with concentration of black chromatophores. Dorsolateral portion of head and body with scattered black chromatophores. Midlateral body silvery. One large and vertical black humeral spot, located over fourth to sixth lateral line scales and extending over 6-7 horizontal series of scales, including lateral line. Midlateral dark stripe extending from humeral region to middle caudal-fin rays, broad in caudal peduncle. Abdominal region almost devoid of black chromatophores. Dorsal, caudal, and anal fins with scattered black chromatophores. Pectoral, pelvic and adipose fins hyaline (Fig. 19).

Sexual dimorphism. Males of Hemibrycon polyodon are easily recognized by the presence of bony hooks on the dorsal-, pectoral-, anal- and pelvic-fin rays. Males and females also slightly differ in pectoral- and pelvic-fin lengths (Table 5) and in anal-fin shape, which is convex in males and nearly straight in females. Gill glands were not found on first gill arch in either males or females.

Distribution. Hemibrycon polyodon is known from the río Pastaza, río Marañon drainage, and upper río Amazonas basin, Ecuador (Fig. 4).

Remarks of Hemibrycon polyodon. Günther (1864) described Tetragonopterus polyodon based on a single specimen from Guayaquil, Ecuador. Eigenmann (1927: 409-410) in his revision of the genus, assigned the distribution of $H$. polyodon as "Coastal streams of Ecuador", also stated that "It is more than probable that the types were shipped from Guayaquil but were collected at a considerable elevation in the interior of Ecuador or Peru".

Recently, Román-Valencia et al. (2007) redescribed $H$. polyodon based in the digital image of holotype and some additional specimens from Santiago and Morona River basins. They furnished an insufficient diagnose for the recognition of the species, and the characters described in their diagnosis 
["aleta dorsal con radios simples y ramificados de igual longitud, una mancha humeral estrecha y verticalmente alargada que alcanza una horizontal trazada desde el borde inferiror del opérculo"] were not found in our analysis of the holotype and non-type specimens of $H$. polyodon. Also, the authors commented that the supraorbital bone is found in this species, as well as other Hemibrycon species, but this bone is absent in all species of Hemibrycon we have examined (see discussion in Bertaco et al., 2007).

Remarks of Hemibrycon coxeyi. The holotype of Hemibrycon coxeyi is badly preserved, lacking several body scales, with dorsal fin and snout broken, and body completely discolored. Only some measurements were taken, as fins length (except dorsal fin), body and caudal peduncle depth, and caudal peduncle length. All scales and fin ray counts were taken, except for the count of anal-fin scale sheath. Fowler (1943: 2) described H. coxeyi based on one of three specimens collected by Mr. W. Judson Coxey in 1931 in Ecuador. The author provided the exact locality according to Coxey trip: "All these specimens are from the basin of the Río Pastaza, in Tungurahua, where he spent some time on the river at the Hacienda Las Mascota". Fowler recognized that $H$. coxeyi was nearly related to $H$. polyodon from the Pacific slope of Ecuador, but he was unable to identify the new species as $H$. polyodon based on Günther's description. Böhlke (1958: 24-25) doubted the type locality of H. coxeyi reported by Fowler ("Hacienda Las Mascota, mouth of the Rio Pastaza, basin of the Rio Maranon, Ecuador") and in footnote cited a reference to the location: "Annals Entomol. Soc. America, vol. 34, no. 4, Dec. 1941, p. 848”. According to Böhlke, this reference places Hacienda Las Mascota at a point far removed from mouth of the Pastaza $\left(01^{\circ} 25^{\prime} \mathrm{S} 78^{\circ} 11^{\prime} \mathrm{W}\right)$, a station occupied on several occasions for some length of time by Coxey. The exact location of mouth of the río Pastaza is about $04^{\circ} 52^{\prime} \mathrm{S} 76^{\circ} 21^{\prime} \mathrm{W}$ according to Böhlke and current maps. Latter, Géry (1962: 66) discussing about the distribution of the known forms of Hemibrycon, commented that $H$. coxeyi is probably a synonym of $H$. huambonicus, and $H$. polyodon comes very probably from the same area of these species. According to Lima et al. (2003) the type locality should be amended to "Ecuador, Napo-Pastaza, Hacienda Mascota, río Topo, a tributary of río Pastaza, $01^{\circ} 25^{\prime} \mathrm{S} 78^{\circ} 11^{\prime} \mathrm{W}$. The type localities of $H$. polyodon and $H$. coxeyi were inexact, but can be in some place of río Pastaza drainage, a relatively large tributary to the left margin of río Marañon, upper río Amazonas basin, in Ecuador.

A comparison of the holotypes of $H$. polyodon and $H$. coxeyi, and new specimens from río Pastaza drainage failed to reveal any differences in examined meristic and morphometric features or other characters. Hemibrycon coxeyi is, therefore, considered a junior synonym of $H$. polyodon, an action previously suggested by Géry (1962).

Remarks of Hemibrycon pautensis Román-Valencia, RuizC. \& Barriga, 2006. Hemibrycon pautensis was described by Román-Valencia et al. (2006) based on specimens collected in río Paute, a tributary of the río Santiago drainage, río Marañon drainage, Ecuador. The río Santiago is nearly located to río Pastaza, both affluents of left margin of río Marañon drainage, in Peru and Ecuador, where also occurs Hemibrycon polyodon. In the original description, one of the characters presented in the diagnosis, the presence of six to seven branched dorsal-fin rays in H.pautensis was not found in the species of Hemibrycon analyzed in this study, as well as in any other Stevardiinae (sensu Mirande, 2009, 2010). Another character used by those authors in the diagnosis of the species, the number of branched anal fin rays (27-28), can be easily found in several species of the genus that were not compared in the diagnosis of their new species. Moreover, the authors presented different values along the text and table for counts of branched rays of anal-fin (27-28 and 25-28) and dorsal-fin (7-8 and 8-9), and number of maxillary teeth (7-11 and 9-11) for that species, respectively. Furthermore, the authors referred to the presence of a supraorbital bone in $H$. pautensis, and other Hemibrycon species, but this bone is absent in all species of Hemibrycon examined (Bertaco et al., 2007).

Analyzing the characters presented in the diagnosis and in the description of $H$. pautensis it is not possible to distinguish this species from $H$. polyodon, also found in the río Santiago drainage according to Román-Valencia et al. (2006). Intriguing, however, the authors did not compare $H$. pautensis with $H$. polyodon in the diagnosis, but only with some of the species of the genus. Therefore, we considered $H$. pautensis a junior synonym of $H$. polyodon.

Material examined. Hemibrycon polyodon, BMNH 1858.7.25.41, holotype, female, $70.4 \mathrm{~mm} \mathrm{SL}$, Guayaquil [Ecuador]. Hemibrycon coxeyi, ANSP 70155, holotype, female (x-ray), $86.0 \mathrm{~mm} \mathrm{SL}$, Hacienda Mascota, río Topo, a tributary of the río Pastaza, drainage of the río Marañon, Napo-Pastaza, Ecuador, 0125'S 78¹1'W, Apr 1931, W. J. Coxey, JC31-MRP-4. Non-type specimens. Ecuador, río Marañon drainage: KU 19978, 1, 45,7 mm SL, río Alpayacu $1 \mathrm{~km}$ E Mera, Pastaza, ca. 01 ${ }^{\circ} 27^{\prime} \mathrm{S} 78^{\circ} 05^{\prime} \mathrm{W}, 23$ Jul 1968. KU 19992, 3, 31.0-78.2 mm SL, río Negro, tributary of río Pastaza $1 \mathrm{~km}$ W of río Negro Twp., Tungurahua, ca. $01^{\circ} 24^{\prime}$ 'S $78^{\circ} 13^{\prime} \mathrm{W}, 26 \mathrm{Jul}$ 1968. KU 19995, 2, 27.7-29.3 mm SL, río Pastaza above río Negro, Tungurahua, $c a .01^{\circ} 24^{\prime}$ 'S $78^{\circ} 13^{\prime}$ W, 26 Jul 1968. KU 20004, 42 of 84 ( 2 c\&s), $15.5-72.3 \mathrm{~mm} \mathrm{SL}, \mathrm{N}$ shore río Pastaza below río Negro (town), Tungurahua, $c a .01^{\circ} 24^{\prime} \mathrm{S} 78^{\circ} 13^{\prime} \mathrm{W}, 26 \mathrm{Jul} 1968$.

\section{Hemibrycon surinamensis Géry, 1962} Figs. 21-22

Hemibrycon surinamensis Géry, 1962: 66 (map with distribution, fig. 1), 71 (diagnosis; fig. 2 - holotype; type locality: brownscreek, km 114 of the railroad ParamariboDam, Paramaracca river basin, Surinam), 72-75 (original description), 78 (in key).

Diagnosis. Hemibrycon surinamensis is distinguished from all congeners, except $H$. divisorensis, by the presence of a wide black asymmetrical spot covering base of caudal-fin rays and extending along entire length of caudal-fin rays 9 to 12 13. Hemibrycon surinamensis differs from $H$. divisorensis by the absence of a black band in the lower half of the caudal 


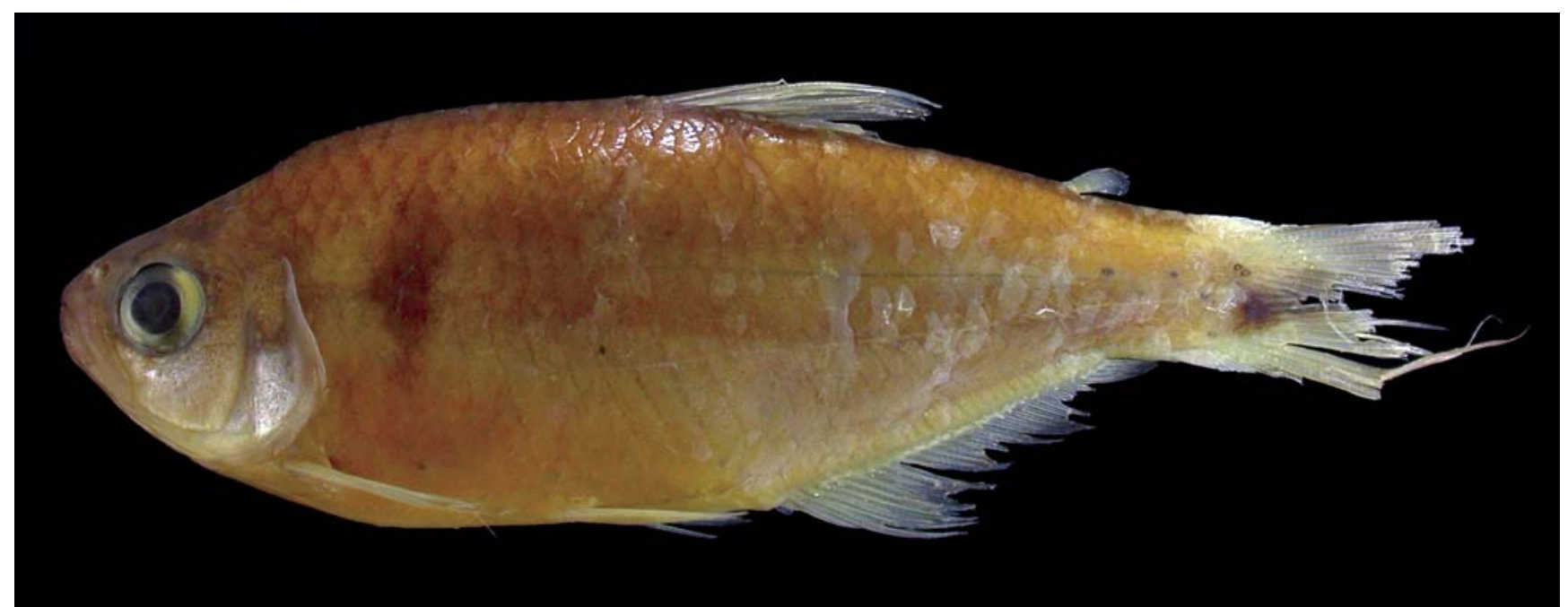

Fig. 21. Hemibrycon surinamensis, ZMA 100347, paratype, female, $65.0 \mathrm{~mm}$ SL, río Paramacca basin, Suriname.

peduncle from the region above the last anal-fin rays to the caudal-fin base, and by the smaller number of scales along anal-fin base scale sheath (15-16 vs. 17-22).

Description. Morphometric data for H. surinamensis summarized in Table 6. Largest male $80.2 \mathrm{~mm}$ SL, largest female $91.5 \mathrm{~mm}$ SL. Body compressed and moderately elongate; greatest body depth at vertical through middle length of pectoral fins. Dorsal body profile convex from nostril to dorsalfin origin, slightly concave in supraocciptal spine; posteroventrally slanted at dorsal-fin base; straight from last dorsal-fin ray to adipose-fin origin. Ventral profile of head convex. Ventral body profile slightly convex to nearly straight from pectoral-fin origin to pelvic-fin origin, and straight to slightly convex to anal-fin origin. Body profile along anal-fin base posterodorsally slanted. Caudal peduncle short, nearly straight to slightly concave along dorsal and ventral margins.

Snout rounded from margin of upper lip to vertical through anterior nostrils. Head small. Mouth terminal. Maxilla long and slightly curved, aligned at angle of approximately $45^{\circ}$ to longitudinal body axis, and its posterior tip extending below orbit, reaching nearly to vertical through center of eye.

Premaxilla with two tooth rows; outer row with 4-6, tricuspid teeth with central cusp slightly longer; inner row with 4 tetra- to pentacuspids teeth, gradually decreasing in length from first to third teeth and last smaller; central cusp twice or three times longer and broader than other cusps. Maxilla fully toothed with 7-14 tricuspid teeth (rarely pentacuspid), except for last four or five conical teeth, with central cusp longer. Three or 4 anteriormost dentary teeth larger, with 5 cusps, followed by medium sized tooth with 35 cusps, and 8-10 teeth with 1-3 cusps or conical; central cusp in all teeth two to three times longer and broader than other cusps. Cusp tips slightly curved posteriorly and lingually (Fig. 22).

Dorsal-fin rays ii,8 $(\mathrm{n}=67)$; first unbranched ray approximately one-half length of second ray. Dorsal-fin origin located posterior to middle of SL and posterior to vertical through pelvic-fin origin. Profile of distal margin of dorsal fin slightly concave. Adipose-fin located approximately at vertical through insertion of last three or four anal-fin ray. Anal-fin rays iii-iv,26-27 (two with 25 three with 28, mode $=27, \mathrm{n}=67$, Fig. 2). First unbranched ray normally only apparent in cleared and stained specimens. Anal-fin profile slightly concave in females and males. Anal-fin origin posterior to vertical through base of last dorsal-fin ray. Anal-fin rays of males bearing one pair of small, elongate, retrorse bony hooks along posterolateral border of each segment of lepidotrichia, usually along last unbranched ray and twelve anterior branched rays; hooks more numerous along second through seventh branched rays. Hooks usually located along posteriormost branch and distal $1 / 2$ to $2 / 3$ of each ray. Pectoral-fin rays i, 10-12 (mode $=11, \mathrm{n}=67)$. Pectoral-fin tip reaching pelvic-fin origin in males but not in females. Pelvic-fin rays i,7 (one with i,8; $n=67$ ). Pelvic-fin origin located anterior to vertical through dorsal-fin origin. Pelvic fin of males usually

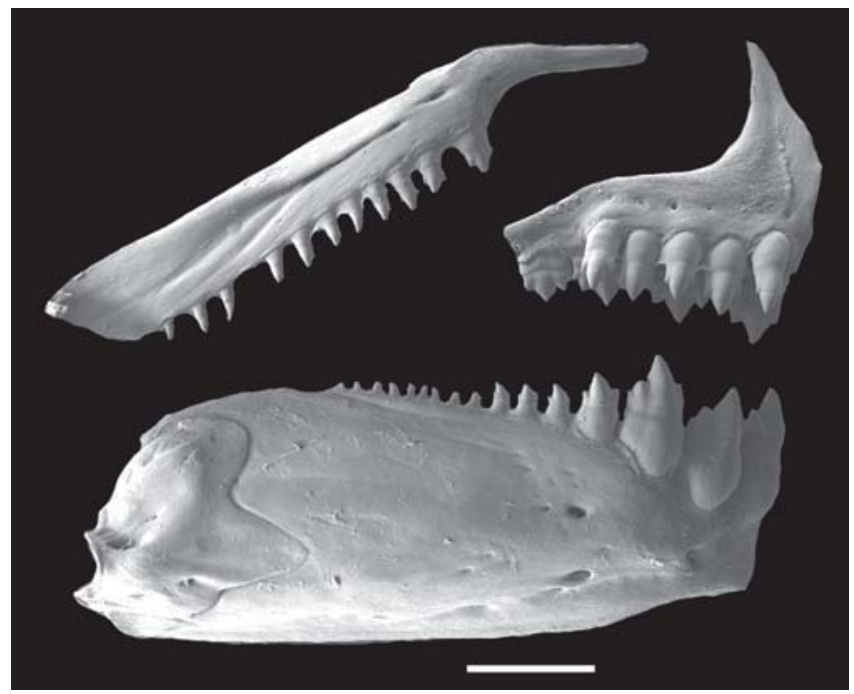

Fig. 22. Hemibrycon surinamensis, MHNG 227928, male, 58.9 $\mathrm{mm}$ SL. Scanning electron micrograph of right side upper and lower jaws. Scale bar $=1 \mathrm{~mm}$. 
Table 6. Morphometric data of paratypes of Hemibrycon surinamensis (MHNG 2182.59, MNHN 1980.1435, ZMA 100.347) from Paramacca River basin, Suriname, and non-types from coastal drainages of the Guiana and Suriname (A - MHNG 1553.54-58, 2179.27, 2182.57, 2182.61-64, 2279.28, 2279.80; MNHN 1989.0046, 1994.0094, 1998.1780, 1998.1931, 2002.3511; ZMA 107.232, 107.275), from rio Tocantins basin (B - MZUSP 30529, 30530), from rio Tapajós basin (C - MNRJ 34433, 34435), and from rio Xingu basin, Brazil (D - MNRJ 34439, 34441, 34443). m, males; f, females. SD = Standard deviation.

\begin{tabular}{|c|c|c|c|c|c|c|c|c|c|c|c|c|c|c|c|c|c|}
\hline & \multicolumn{4}{|c|}{ Paratypes } & \multicolumn{3}{|c|}{ A } & \multicolumn{4}{|c|}{$\mathrm{B}$} & \multicolumn{2}{|c|}{$\mathrm{C}$} & \multicolumn{4}{|c|}{ D } \\
\hline & $\mathrm{n}$ & Range & Mean & SD & $\mathrm{n}$ & Range & Mean & $\mathrm{SD} n$ & Range & Mean & $\mathrm{SD} n$ & Range & Mean & SD n & $n \quad$ Range & Mean & $\mathrm{SD}$ \\
\hline Standard leng & 7 & $53.3-64.8$ & 57.5 & - & 65 & $\begin{array}{r}33.5-91.5 \\
\text { Percen }\end{array}$ & $\begin{array}{c}64.7 \\
\text { ts of S }\end{array}$ & $\begin{array}{c}-20 \\
\text { tandard } 1\end{array}$ & $\begin{array}{l}38.6-87.1 \\
\text { length }\end{array}$ & 54.3 & & $39.5-45.6$ & 42.7 & -7 & $738.9-60.2$ & 48.1 & - \\
\hline Predorsal distance & 7 & $49.5-54.2$ & 51.0 & 1.6 & & $48.4-55.1$ & 51.1 & 1.520 & 53.0 & 51.5 & 1.05 & $51.9-53.4$ & 52.7 & 0.67 & 750.6 & 51.9 & 0.9 \\
\hline & 7 & -47.4 & 44.5 & 5 & 65 & $0.9-49.2$ & 45.4 & 1.620 & $1.7-47.6$ & 45.0 & 1.45 & 46. & 46.5 & 0.47 & 743. & 46.2 & 1.1 \\
\hline & 7 & $23.2-25.1$ & 24.3 & 0.7 & & -25.8 & 24.2 & 0.820 & 26.7 & 24.8 & 1.05 & $25.2-26.2$ & 25.7 & 0.47 & 723. & 25.4 & 1.3 \\
\hline & 7 & 59.0 & 61.1 & 2.0 & 6 & 5.1 & 62.0 & 1.720 & 3.0 & 60.6 & 1.55 & 61.6-63.5 & 62.4 & 0.77 & 760. & 61.4 & 0.8 \\
\hline & 3 & $31.2-32.0$ & 32.0 & 0.7 & & -39.5 & 35.5 & 1.78 & $31.8-38.2$ & 34.9 & $2.0-$ & - & - & & $234.5-37.5$ & 36.0 & 2.1 \\
\hline & 4 & -37.1 & 34.0 & 2.5 & 46 & -42.7 & 37.1 & 2.112 & 8.0 & 34.4 & 2.25 & $36.2-39.3$ & 37.6 & 1.15 & 533 & 36.4 & 2.2 \\
\hline & 7 & $9.7-12.8$ & 11.1 & .0 & 65 & 10.0 & 11.7 & 0.620 & 2.0 & 10.8 & 0.65 & 11. & 12.2 & 0.37 & 711 & 12.2 & 0.3 \\
\hline & 7 & $9.1-13.9$ & 11.9 & 1.5 & 65 & & 12.3 & 1.120 & 4.5 & 12.7 & 0.85 & 11.0 & 11.7 & 0.67 & & 12.0 & 0.8 \\
\hline & 7 & $30.8-33.4$ & 32.0 & 0.9 & 65 & 29. & 32.4 & 1.320 & & 32.6 & 1.05 & 32.4 & 33.2 & 0.77 & 73 & 33.4 & 1.6 \\
\hline & 7 & $24.4-27.5$ & 25.3 & 1.0 & 65 & 22.0 & 24.6 & 0.920 & 5.7 & 23.9 & 1.05 & $23.9-25.5$ & 24.8 & 0.67 & 725 & 25.4 & 0.3 \\
\hline & 3 & $2-15.8$ & 15.4 & 0.3 & & 7.1 & 16.1 & 0.78 & 7.2 & 16.2 & $0.7-$ & - & - & & 215 & 16.1 & 0.6 \\
\hline & 4 & 17.6 & 16.7 & 0.7 & & 7.6 & 15.6 & 0.912 & 6.1 & 15.1 & 0.75 & $15.5-16.1$ & 15.8 & 0.35 & 514 & 15.6 & 0.7 \\
\hline & 3 & $20.8-22.0$ & 21.3 & 0.6 & & 20.4 & 21.7 & 0.88 & 20.7 & 22.1 & $0.9-$ & - & - & & 221 & 22.1 & 0.4 \\
\hline & 4 & $20.7-22.9$ & 22.2 & 1.0 & & $19.5-24.1$ & 21.7 & 1.012 & $20.7-22.3$ & 21.3 & 0.55 & $21.6-$ & 22.2 & 0.55 & 520. & 22.6 & 1.2 \\
\hline Head length & 7 & $22.4-25.3$ & 24.0 & 1.0 & & $\begin{array}{r}\text { 21.1-25.7 } \\
\text { Perce }\end{array}$ & 23.1 & 0.820 & $21.9-25.1$ & 23.3 & 1.05 & $24.4-26.2$ & 25.0 & 0.77 & 7 22.9-25.8 & 24.3 & 1.1 \\
\hline & & & 24.2 & & & & 23.9 & 1.020 & $22.2-25.2$ & 23.6 & 0.95 & & 24 & 0.67 & & 24.9 & 0.9 \\
\hline & 7 & $45.4-48.1$ & 46.7 & 1.0 & & $42.7-49.8$ & 46.7 & 1.520 & $43.7-49.2$ & 47.1 & 1.35 & $46.0-52.4$ & 48.5 & 2.57 & 745.4 & 48.4 & 1.5 \\
\hline & 7 & $31.9-35.6$ & 33.9 & 1.2 & & $30.1-37.4$ & 33.7 & 1.520 & & 34.7 & 2.35 & $30.0-34.5$ & 32.9 & 1.67 & 732.5 & 34.3 & 1.9 \\
\hline Interorbital width & 7 & $33.2-35.9$ & 34.7 & 1.0 & 65 & $32.0-40.1$ & 36.7 & 1.320 & $34.4-39.7$ & 36.5 & 1.45 & $33.5-37.0$ & 34.7 & 1.47 & $7 \quad 33.8-38.1$ & 36.3 & 1.8 \\
\hline
\end{tabular}

bearing 1 retrorse bony hook per segment of lepidotrichia along ventromedial border of second to ninth branched rays. Caudal fin forked with 19 principal rays without bony hooks $(n=67)$; lobes similar in size. Dorsal procurrent rays 10-11, and ventral procurrent rays 9-11 $(n=6)$.

Scales cycloid, moderately large. Lateral line complete with 39-41 (mode $=41, n=62$, Fig. 3 ). Scale rows between dorsal-fin origin and lateral line $6-7(\operatorname{mode}=7, \mathrm{n}=67)$; scale rows between lateral line and pelvic-fin origin $4-5$ (mode $=5$, $\mathrm{n}=67$ ). Predorsal scales $12-15$, arranged in regular series $($ mode $=13)$. Scales rows around caudal peduncle 14. Axillary scale on pelvic-fin origin extends posteriorly covering 2-3 scales. Scale sheath along anal-fin base with 12-17 scales in single series, extending to base of eighth to fourteenth branched rays.

Precaudal vertebrae 16-17; caudal vertebrae 21-22; total vertebrae 38-39 $(n=10)$. Supraneurals 6-7 $(n=6)$. Gill rakers on upper limb of outer gill arch 7-9, and on lower limb 11-12 ( $n=12)$.

Color in alcohol. General ground body color yellowish. Dorsal and dorsolateral portion of head and body pigmented dark brown. One black humeral spot narrow, larger and vertically elongate, located over fifth to sixth lateral line scales and extending over 5-6 horizontal series of scales, including lateral line. Midlateral body stripe broad silvery extending from humeral region to caudal peduncle. A wide black spot covering base of caudal-fin rays and extending about median rays. Dorsal fin with dark pigmentation diffuse, and anal fin with small black chromatophores along its border forming narrow stripe in some specimens. Other fins without distinctive marks (Fig. 21).
Sexual dimorphism. Males of Hemibrycon surinamensis are easily recognized by the presence of bony hooks on the dorsal-, anal-, pelvic-, and pectoral-fin rays. Males and females also slightly differ in pectoral- and pelvic-fin lengths, and body depth (Table 6). Mature males with gill gland on first gill arch, covering the first branchial filaments.

Distribution. Hemibrycon surinamensis is known from coastal basins of French Guiana and Suriname (Paramacca and Maroni basins), and from lower rios Tapajós, Tocantins and Xigu basins, Pará, Brazil (Fig. 4).

Remarks. Géry (1962) described Hemibrycon surinamensis from the basin of Paramacca River, Suriname, based on his particular fish collection. Géry gave the catalog number of only one lot of paratypes from ZMA fish collection (ZMA 100347, paratype), and listed the remaining lots as belonging to his particular fish collection (Holotype Nr. M. 107; and 9 paratypes Nr. M. 107.2-11, except Nr. 4). Later, the holotype was donated to ZMA (catalogued as ZMA 104188), and the paratypes were distributed to MHNG and MNHN fish collections. Planquette et al. (1996) collected several specimens and lots of $H$. surinamensis in some river basins from French Guiana, as the Maroni, Approuague, Comté and Mana. In the 1980 decade, Michael Goulding makes several collecting expeditions in the Amazon basin, including the rio Tocantins. Most of the fishes collected by Goulding are located at MZUSP, but a large portion has not been cataloged. We have analyzed the lots of Hemibrycon collected by Goulding in 1983 in the rio Itacaiúnas, lower rio Tocantins basin and concluded that is the same species from Suriname 
and French Guiana, H. surinamensis. No significant difference was found between the Suriname/French Guiana and Tocantins populations. Recently, new Hemibrycon specimens were collected in lower Tapajós and Xingu river basins (Delineamento da Ecorregião Aquática Xingu-Tapajós Project, CETEM, RJ), and after an examination, we conclude that also belong to $H$. surinamensis.

Material examined. Paratypes. MHNG 2182.59, 1 of 2, 57.1 mm SL, brownkreek sur $114 \mathrm{~km}$ railroad Paramacca River basin, Suriname, 6 Nov 1960 (origin ZMA). MNHN 1980.1435, 1, 53.3 mm SL, Suriname, Nov 1960, H. P. Pijpers. ZMA 100.347, 4 of 7, 55.0-64.8 mm SL, Paramacca River basin, Brownscreek, 8 km NW of Brownsweg Village, km 14 of the railroad ParamariboDam, Suriname, 6 Nov 1960, H. P. Pijpers. Non-type specimens. French Guiana: MHNG 2179.27, 2, 74.6-76.3 mm SL, crique Cochou, environ de Saul, Maroni, 7 Jun 1983 (coll. J. Géry 107). MHNG 2279.28, 12 (2 c\&s), 51.5-91.5 mm SL, bassin Mana, eau claire environ de Saül, 1983 (coll. Géry 107). MHNG 2182.61, 3, 53.2-80.2 mm SL, crique Balatés, Maroni River drainage. MHNG 2182.62, 2, 35.8-73.6 mm SL, crique Balatés, 9 Oct 1979 (coll. J. Géry 107). MHNG 2182.63, 6, 29.5-75.5 mm SL, riviere Conté, crique Blanche, 3 Oct 1979 (coll. Géry 0107). MNHN 1989.0046, 1, $43.3 \mathrm{~mm} \mathrm{SL}$, crique Japigny, río Approuague drainage, Cayenne, Meunier at Pascal Boujard, Nov 1988. MNHN 1994.0094, 1, $38.5 \mathrm{~mm} \mathrm{SL}$, Arataye River, Approuague River drainage, Saut parare, Cayenne, $c a .04^{\circ} 02^{\prime} \mathrm{N} 52^{\circ} 42^{\prime} \mathrm{W}$, Meunier at Pascal Boujard, Nov 1988. MNHN 1998.1780, 2, 59.8-72.0 mm SL, Tampoc, $c a$. $03^{\circ} 20^{\prime} \mathrm{N} 53^{\circ} 45^{\prime} \mathrm{W}$, río Maroni drainage, Filet Haut, St. Laurent du Maroni, 26 Nov 1998. MNHN 1998.1931, 11, 35.5-77.1 mm SL, Grand Inini, Maroni River drainage, St. Laurent du Maroni, 27 Sep 1997. MNHN 2001.1944, 8, 26.2-37.4 mm SL, crique Blanche, Comté River drainage, Cayenne, 3 Oct 1979. MNHN 2001.2513, 13, 23.4-37.1 mm SL, Approuague River drainage, Decouverte, Cayenne, 10 Nov 2003. MNHN 2002.3511, 10, 69.8-88.7 mm SL, Alama, Maroni River drainage, Mitaraka, St. Laurent du

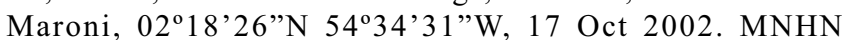
2004.1199, 2, 35.4-39.6 mm SL, Petit Approuague, Orapu River drainage, Cayenne, 9 Nov 2003. Suriname: MHNG 1553.54-58, 5, 46.8-77.3 mm SL, Torrent rocheux dans le Brownberg national Parck, Oct 1976. MHNG 2182.57, 1, 52.6 mm SL, Maroni creek, 7 Jul 1949 (coll. Géry M. 58). MHNG 2182.64, 1, 69.5 mm SL, torrent rocheux ds le Brownsberg National Park, Feb 1977 (coll. J. Géry 107). MHNG 2279.80, 1, $69.6 \mathrm{~mm} \mathrm{SL}$, Maroni, crique grand fossé, env. de Saul, 7 Jun 1983 (coll. J. Géry 107). ZMA 107.232, 11, 49.0-74.2 mm SL, district Saramacca, Coppename River on northern slope of Wilhelmina Mountains, ca. $03^{\circ} 49^{\prime} \mathrm{N} 56^{\circ} 57^{\prime} \mathrm{W}$, 17 May 1967. ZMA 107.275, 4, 53.2-82.9 mm SL, Kamaloea (= Saloea) Creek at right bank of Marowijne River, $9 \mathrm{~km} \mathrm{SE}$ of Gran Creek, district Marowijne, 24 Apr 1967. Brazil, Pará. Lower rio Tapajós basin: MNRJ 34433, 3, 39.5-45.7 mm SL, igarapé tributary of rio Uruará, $4 \mathrm{~km}$ west of Uruará, $03^{\circ} 43^{\prime} 57^{\prime} \mathrm{S}$ 5346'29"W, 26 Sep 2008. MNRJ 34435, 3, 32.6-45.4 mm SL, igarapé at Balneário Cachoeira, Rurópolis, 0408'00"S 5453'41' 'W, 27 Sep 2008. MNRJ 34437, 9, 27.4-35.0 mm SL, igarapé at road Transamazônica, ca. 52 km of Rurópolis, Rurópolis, $04^{\circ} 07^{\prime} 52^{\prime \prime S}$ $55^{\circ} 13^{\prime} 42^{\prime \prime} \mathrm{W}, 27$ Sep 2008. Lower rio Tocantins basin: MZUSP $30529,23$ of 26 ( $3 \mathrm{c} \& \mathrm{~s}), 32.7-87.1 \mathrm{~mm} \mathrm{SL}$; MCP 17074, $1 \mathrm{c} \& \mathrm{~s}$, $51.9 \mathrm{~mm}$ SL, río Itacaiúnas, Caldeirão, 15 Oct 1983. MZUSP 30530, 5, 44.9-68.8 mm SL, río Itacaiúnas, estrada de Ferro, $10 \mathrm{~km}$ leste do N-4, ca. $05^{\circ} 52^{\prime}$ 'S $50^{\circ} 32^{\prime} \mathrm{W}, 13$ Oct 1983 . MZUSP 31840 ,
1,77.5 mm SL, río Itacaiúnas, Igarapé Pojuca, Caldeirão, Serra dos Carajás, $c a .05^{\circ} 52^{\prime} \mathrm{S} 50^{\circ} 32$ 'W, 5 Oct 1983 . Lower rio Xingu basin: MNRJ 34439, 12, 30.1-43.4 mm SL, córrego do Mico, affluent of rio Fresco, tributary of rio Juari, ca. $7 \mathrm{~km} \mathrm{NW}$ of Bannach, Bannach, $07^{\circ} 18$ ' $15^{\prime \prime}$ S $50^{\circ} 26^{\prime} 46^{\prime \prime} \mathrm{W}, 10$ Oct 2008. MNRJ 34441, 3, 54.2-60.0 mm SL, affluent of rio Fresco, tributary of rio Juari, $c a$. $1 \mathrm{~km}$ E of Jauri, Ourilândia do Norte, $07^{\circ} 13$ '24"S 50³7'10"W, 10 Oct 2008. MNRJ 34443, 1, $41.5 \mathrm{~mm}$ SL, igarapé Manguari, km 28, São Félix do Xingu, 06³5'42”S 5148’48”W, 12 Oct 2008.

\section{Hemibrycon taeniurus (Gill, 1858) Figs. 23-24}

Poecilurichthys taeniurus Gill, 1858: 418 (original description; type locality: Island of Trinidad).

Tetragonopterus taeniurus. -Günther, 1864: 317 (Trinidad).

Tetragonopterus (Hemibrycon) trinitatis Lütken, 1875: 234 (original description; type locality: Trinidad Island, West Indies). -Eigenmann, 1927: 412 (synonym of $H$. taeniurus Gill, Trinidad). -Lima et al., 2003: 159 (species inquirenda in Characidae).

Tetragonopterus guppyi Regan, 1906:384 (original description; 5 type specimens $65-85 \mathrm{~mm}$ TL; type locality: Glenside Estate stream, at the foot of the n. range of hills, Trinidad I.). [NEW SYNONYM]

Hemibrycon taeniurus. -Eigenmann, 1909: 327 (listed).

Hemibrycon guppyi. -Eigenmann, 1909: 327 (listed; distribution: Trinidad).

Hemibrycon guppii [error]. -Eigenmann, 1910: 432 (listed; distribution: Trinidad).

Diagnosis. Hemibrycon taeniurus is distinguished from most of its congeners by the number of branched anal-fin rays (2529 vs. 15-24, Fig. 2). From the species sharing similar lateral line counts, it differs from $H$. boquiae by the number of scale rows above lateral line ( $8 v s .6-7)$, and by the total number of vertebrae (39-41 vs. 41-43); from $H$. brevispini by the number of cusps of three anteriormost dentary teeth (5vs. 3), and by absence of bony hooks in the caudal-fin rays of males ( $v s$. presence); from $H$. cairoense, $H$. huambonicus and $H$. polyodon by the number of lateral line scales (40-42 vs. 43-46, 44-48 and 42-45, respectively); from $H$. dariensis by the number of cusps of second tooth of premaxillary inner row teeth ( $5 v s .7)$, and by the absence of pigment in the distal tip of rays just above and below to middle caudal-fin rays; from $H$. divisorensis and $H$. surinamensis by the absence of a wide black asymmetrical spot covering base of caudal-fin rays; from $H$. inambari by the number of scales along anal-fin base scale sheath (10-15 vs. 6-10); from H.jabonero by the number of caudal peduncle scales (16 vs. 14); from H. jelskii by the size of humeral spot (over 4-5 vs. 7-9 horizontal series of scales); from $H$. metae by the number of cusps of second tooth of premaxillary inner row teeth (5 vs. 7); from $H$. quindos by the number of scale rows above lateral line ( $8 v s .5-7)$; and from $H$. raqueliae by the number of predorsal scales (15-19 $v s .10-13)$ and by the number of cusps of first maxillary tooth (3vs. 5). 


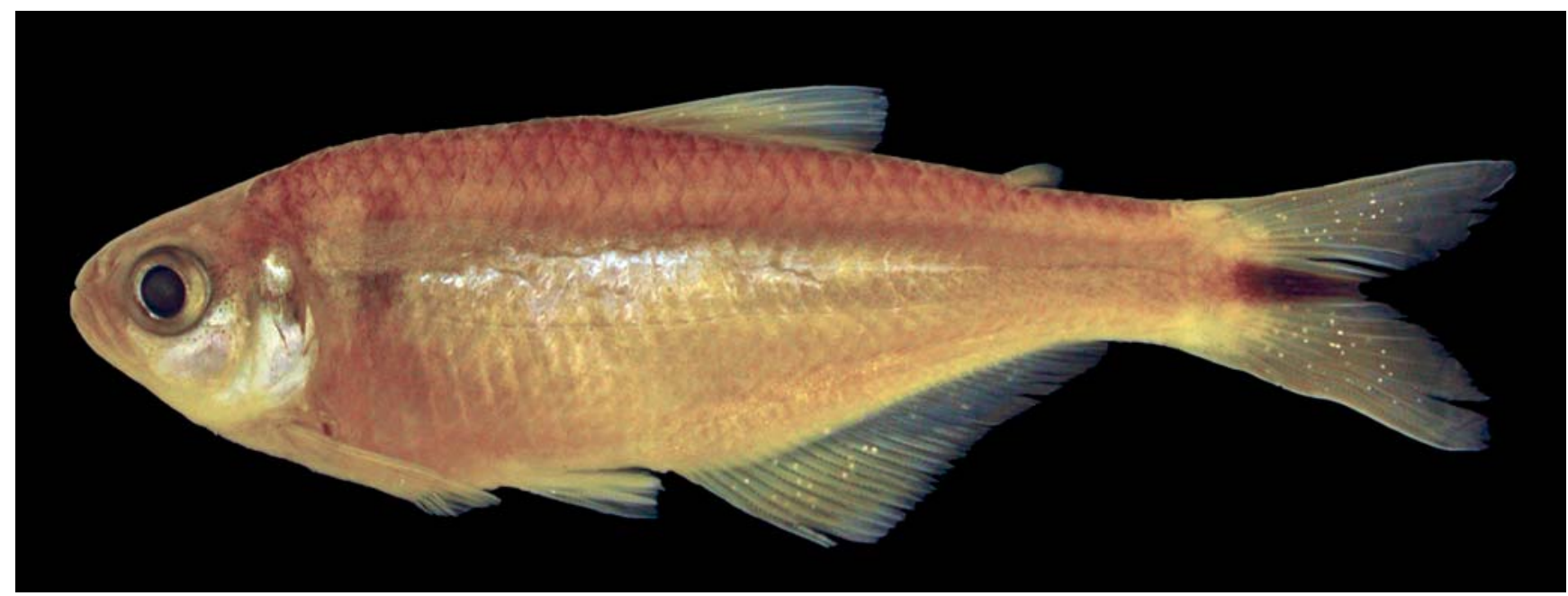

Fig. 23. Hemibrycon taeniurus, AMNH 215239, male, $68.5 \mathrm{~mm}$ SL, Island of Trinidad, Trinidad and Tobago.

Description. Morphometric data for H.taeniurus summarized in Table 7. Largest male $65.1 \mathrm{~mm} \mathrm{SL}$, largest female $81.8 \mathrm{~mm}$ SL. Body compressed and moderately elongate; greatest body depth anterior to dorsal-fin origin. Dorsal profile of head slightly convex. Dorsal body profile convex from occipital bone to base of last dorsal-fin ray; straight from this point to adipose-fin origin. Ventral profile of head slightly convex. Ventral body profile convex from pectoral-fin origin to pelvicfin origin, and straight to slightly convex to anal-fin origin. Body profile along anal-fin base posterodorsally slanted. Caudal peduncle elongate, nearly straight to slightly concave along dorsal and ventral margins.

Snout rounded from margin of upper lip to vertical through anterior nostrils. Head small. Mouth terminal, mouth slit nearly at horizontal through middle of eye. Maxilla long and slightly curved, aligned at angle of approximately $45^{\circ}$ to longitudinal body axis, and its posterior tip extending below orbit, reaching nearly to vertical through center of eye.

Premaxilla with two tooth rows; outer row with 4-6, tricuspid teeth with central cusp slightly longer; inner row with 4 tetrato pentacuspids teeth, gradually decreasing in length from first to third teeth and last smaller; central cusp twice or three times longer and broader than other cusps. Maxilla toothed with 7-15 uni- to tricuspid teeth, with central cusp longer. Three anteriormost dentary teeth larger, with 5 cusps, followed by medium sized tooth with 3-5 cusps, and 10-13 teeth with 13 cusps or conical; central cusp in all teeth two to three times longer and broader than other cusps. Cusp tips slightly curved posteriorly and lingually (Fig. 24).

Dorsal-fin rays ii,8 $(n=39)$; first unbranched ray approximately one-half length of second ray. Dorsal-fin origin located posterior to middle of SL and posterior to vertical through pelvic-fin origin. Profile of distal margin of dorsal fin nearly straight to slightly concave. Males with bony hooks in distal one-third of first branched rays. Adipose-fin located at vertical through insertion of last anal-fin rays. Anal-fin rays ii-vi,26-29 (two with 25 , mode $=27, n=39$, Fig. 2 ). Anal-fin profile slightly concave in males and females. Anal-fin origin approximately at vertical through insertion in the last dorsal fin rays. Anal-fin rays of males bearing one pair of developed bony hooks along posterolateral border of each segment of lepidotrichia, along last unbranched ray and twelfth to fifth branched rays, and small bony hooks on remaining rays. Hooks usually located along posteriormost branch and distal $1 / 2$ to $2 / 3$ of each ray. Pectoral-fin rays i, 10-12 (mode $=11, \mathrm{n}=39$ ). Pectoral-fin tip surpassing pelvic-fin origin in males and nearly reaching in females. Males with bony hooks on distal portion of unbranched and all branched rays. Pelvic-fin rays i,6,i (rarely i,7, $n=39$ ). Pelvic-fin origin located 4-5 predorsal scales anterior to vertical through dorsal-fin origin. Pelvic fin of males usually bearing 1 small bony hook per segment of lepidotrichia along ventromedial border of all branched rays. Caudal fin forked with 19 principal rays without bony hooks $(n=39)$; lobes similar in size. Caudalfin base have a few scales. Dorsal procurrent rays 11-13, and ventral procurrent rays $10-12(n=7)$.

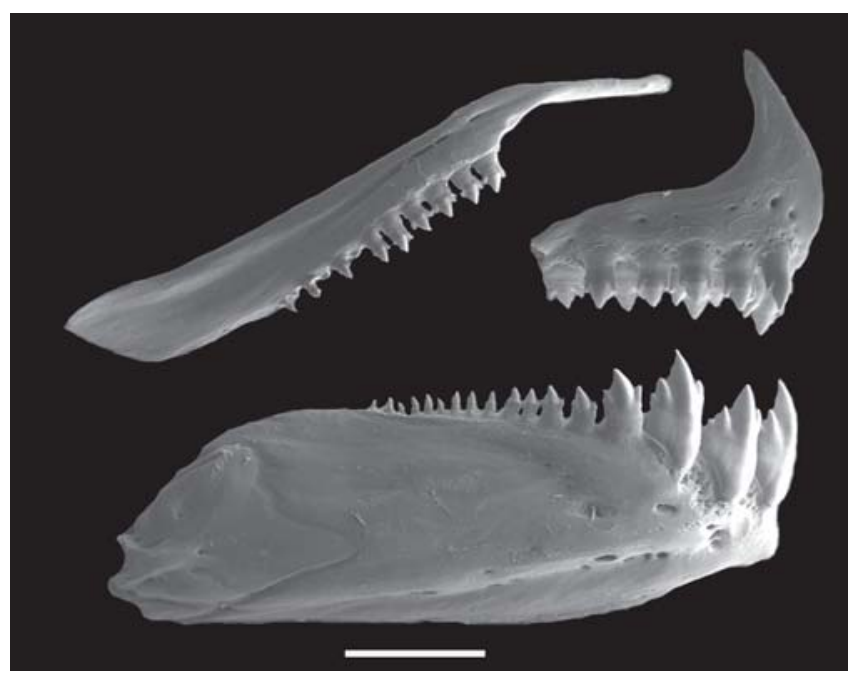

Fig. 24. Hemibrycon taeniurus, MCNG 8199, female, 57.5 mm SL. Scanning electron micrograph of right side upper and lower jaws. Scale bar $=1 \mathrm{~mm}$. 
Table 7. Morphometric data of syntypes of Hemibrycon guppyi (= H. taeniurus, BMNH 1906.6.23.13-17), and syntypes of $H$. taeniurus (ZMUC 962-963, ZMUC 966-968), and non- types of H. taeniurus (AMNH 215239, 215301; INHS 40083; MCNG 8199; ROM 61651; USNM 290408, 290413) from Island of Trinidad, Trinidad and Tobago. $\mathrm{m}$, males; f, females. SD=Standard deviation.

\begin{tabular}{|c|c|c|c|c|c|c|c|c|c|c|c|c|}
\hline & \multirow{2}{*}{\multicolumn{4}{|c|}{$\begin{array}{l}\text { H. guppyi } \\
\text { Syntypes }\end{array}$}} & \multicolumn{8}{|c|}{ H. taeniurus } \\
\hline & & & & & \multicolumn{4}{|c|}{ Syntypes } & \multicolumn{4}{|c|}{ Non-types } \\
\hline & $\mathrm{n}$ & Range & Mean & SD & $\mathrm{n}$ & Range & Mean & SD & $\mathrm{n}$ & Range & Mean & SD \\
\hline Standard length (mm) & 5 & $46.3-73.4$ & 57.5 & - & 5 & $33.0-50.6$ & 42.1 & - & 26 & $36.9-81.8$ & 62.4 & - \\
\hline \multicolumn{13}{|c|}{ Percents of Standard length } \\
\hline Predorsal distance & 5 & $49.5-55.5$ & 52.0 & 2.2 & 5 & $51.6-55.7$ & 53.4 & 1.8 & 26 & $47.6-52.4$ & 50.6 & 1.3 \\
\hline Prepelvic distance & 5 & $38.8-42.7$ & 41.1 & 1.5 & 5 & $41.2-46.4$ & 43.7 & 2.1 & 26 & $39.2-46.5$ & 42.9 & 1.7 \\
\hline Prepectoral distance & 5 & $22.8-23.9$ & 23.4 & 0.5 & 5 & $22.0-24.2$ & 23.0 & 0.8 & 26 & $20.8-24.0$ & 22.2 & 0.8 \\
\hline Preanal distance & 5 & $54.6-59.8$ & 57.4 & 2.1 & 5 & $54.4-60.7$ & 58.2 & 2.6 & 26 & $53.9-61.9$ & 58.4 & 2.0 \\
\hline Depth at dorsal-fin origin (m) & 2 & $31.4-32.3$ & 31.9 & 0.6 & 3 & $29.4-30.8$ & 30.0 & 0.7 & 6 & $28.8-33.2$ & 30.5 & 1.6 \\
\hline Depth at dorsal-fin origin (f) & 3 & $33.3-35.5$ & 34.3 & 1.1 & 2 & $31.9-33.3$ & 32.6 & 1.0 & 20 & $30.1-39.1$ & 35.0 & 2.3 \\
\hline Caudal peduncle depth & 5 & $11.8-12.7$ & 12.3 & 0.3 & 5 & $10.0-11.2$ & 10.6 & 0.4 & 26 & $10.8-12.9$ & 11.7 & 0.5 \\
\hline Caudal peduncle length & 5 & $12.0-14.2$ & 13.2 & 1.0 & 5 & $12.7-14.0$ & 13.3 & 0.5 & 26 & $11.6-15.0$ & 13.1 & 0.8 \\
\hline Anal-fin base & 5 & $32.0-34.9$ & 33.2 & 1.0 & 5 & $31.8-34.5$ & 33.4 & 1.0 & 26 & $31.7-36.2$ & 33.9 & 1.1 \\
\hline Dorsal-fin length & 5 & $22.5-24.4$ & 23.3 & 0.9 & 5 & $22.1-24.2$ & 23.7 & 0.9 & 26 & $22.2-26.1$ & 23.9 & 1.0 \\
\hline Pelvic-fin length (m) & 2 & $15.1-15.3$ & 15.2 & 0.2 & 3 & $14.7-16.7$ & 15.5 & 1.0 & 6 & $13.7-15.3$ & 14.6 & 0.7 \\
\hline Pelvic-fin length (f) & 3 & $13.2-15.0$ & 14.4 & 1.0 & 2 & $14.1-14.5$ & 14.3 & 0.3 & 20 & $12.3-15.3$ & 14.2 & 0.7 \\
\hline Pectoral-fin length (m) & 2 & $19.9-20.1$ & 20.0 & 0.1 & 3 & $20.7-21.6$ & 21.3 & 0.5 & 6 & $19.7-21.4$ & 20.4 & 0.6 \\
\hline Pectoral-fin length (f) & 3 & $18.3-20.5$ & 19.5 & 1.1 & 2 & $21.0-21.4$ & 21.2 & 0.2 & 20 & $19.0-22.2$ & 20.6 & 0.7 \\
\hline Head length & 5 & $21.8-23.3$ & 22.5 & 0.6 & 5 & $22.9-24.7$ & 23.8 & 0.8 & 26 & $21.0-23.6$ & 22.3 & 0.6 \\
\hline \multicolumn{13}{|c|}{ Percents of Head length } \\
\hline Snout length & 5 & $23.4-26.8$ & 24.8 & 1.0 & 5 & $21.8-24.5$ & 23.0 & 1.0 & 26 & $19.5-24.6$ & 22.3 & 1.0 \\
\hline Upper jaw length & 5 & $42.7-47.9$ & 44.5 & 2.2 & 5 & $45.4-50.0$ & 47.7 & 1.9 & 26 & $42.5-47.3$ & 45.6 & 1.2 \\
\hline Orbital diameter & 5 & $33.6-38.6$ & 36.4 & 2.0 & 5 & $35.0-36.8$ & 36.1 & 0.7 & 26 & $29.4-37.3$ & 32.5 & 1.8 \\
\hline Interorbital width & 5 & 31.6-32.9 & 32.3 & 0.5 & 5 & $31.4-32.5$ & 32.0 & 0.4 & 26 & $31.3-35.5$ & 33.3 & 1.2 \\
\hline
\end{tabular}

Scales cycloid, moderately large. Lateral line complete with $40-42$ (mode $=40, n=39$, Fig. 3 ). Scale rows between dorsalfin origin and lateral line $8(n=39)$; scale rows between lateral line and pelvic-fin origin $5-6($ mode $=6, n=39)$. Predorsal scales $13-16$, arranged in regular series $(\operatorname{mode}=14, \mathrm{n}=36)$. Scales rows around caudal peduncle $16(n=38)$. Axillary scale on pelvic-fin origin extends posteriorly covering 2-3 scales. Scale sheath along anal-fin base with 10-15 scales in single series, extending to base of most anterior branched rays.

Precaudal vertebrae 17-18; caudal vertebrae 22-24; total vertebrae 39-41 $(\mathrm{n}=7)$. Supraneurals 5-7 $(\mathrm{n}=7)$. Gill rakers on upper limb of outer gill arch 7-8, and on lower limb 11-13 $(n=25)$.

Color in alcohol. Holotype discolored. Color description based on non-type specimens. General ground body color yellowish. Dorsal portion of head and body with concentration of black chromatophores. Dorsolateral portion of head and body with scattered black chromatophores. One large and vertical black humeral spot, located over third to fifth lateral line scales and extending over 4-5 horizontal series of scales, including lateral line. Midlateral dark stripe extending from humeral region to middle caudal-fin rays, broad in the caudal peduncle. Abdominal region almost devoid of black chromatophores. Dorsal and caudal fin with black pigmentation diffuse and anal fin with small black chromatophores along its border forming narrow stripe. Pectoral, pelvic and adipose fins hyaline (Fig. 23).

Sexual dimorphism. Males of Hemibrycon taeniurus are easily recognized by the presence of bony hooks on the dorsal-, pectoral-, anal- and pelvic-fin rays. Males and females slightly differ in pectoral- and pelvic-fin lengths and body depth (Table 7). Mature males with gill gland on first gill arch, covering the first branchial filaments.

Distribution. Hemibrycon taeniurus is known inhabiting river basins from West Trinidad Island, Trinidad and Tobago (Fig. 4).

Remarks. Theodore Gill described Poecilurichthys taeniurus in 1858 when he traveled to the West Indian Islands. In his original description Gill (1858: 418-419) did not provide a catalog number nor museum name for the type material, but the author remarked that "specimens of most of the species which are being described have been deposited in the museum of the Smithsonian Institution, and in the private cabinets of Messrs. Stewart \& Brevoort". Vari \& Howe (1991) report no type specimens of $P$. taeniurus in the Smithsonian catalog of type specimens of Characiformes.

Later in 1875, Christian Lütken redescribed Tetragonopterus taeniurus (Gill) and described Tetragonopterus (Hemibrycon) trinitatis from Trinidad. Lütken did not explain to which museum belong the specimens used in his descriptions. According to Lütken (1875: 234) a glass of "tetragonopters" from Trinidad, that Mr. Riise obtained from Dr. (?Hr.) Gill at his return from that island, classified as Brevortia [sic] taeniata Gill, contained two specimens of T. taeniurus (Gill), and seven specimens of a form that looks closely related to Tetragonopterus. These seven specimens were found to lack the dark humeral spot, and to have a maxilla equipped with small teeth in a greater part of its length, being referred by Lütken to the subgenus Hemibrycon, as T. (H.) trinitatis. 
Regan (1906: 383-384) redescribed T. taeniurus based on two specimens from Trinidad, reporting that received one specimen from the Copenhagen Museum as T. trinitatis, commenting: "Gill's description of T. taeniurus is, so far it goes, perfectly applicable to $T$. trinitatis, and there can be but little doubt of their identify". In the same work, Regan proposed a new species, H. guppyi, from Trinidad Island, and presented the only possible differences between these species: " $H$. taeniurus has diameter of eye 2.5 in the HL and a little greater than interorbital width, and $H$. guppyi has diameter of eye 3-3.5 in the HL and less than interorbital width".

In the catalog of fish types of Zoological Museum of Copenhagen, Nielsen (1974) reported the five syntypes of Tetragonopterus trinitatis (ZMUC 962, 963, 966-968), referring the species as a synonym of Hemibrycon taeniurus (Gill). Lütken worked at ZMUC from 1852 to 1899 (Alves \& Pompeu, 2001) and probably the specimens were carried by him for that institution or donated by Gill.

Boeseman (1960) in "The fresh-water fishes of the island of Trinidad" provided a table with some distinct characters for H. taeniurus and H. guppyi. Boeseman (1960) and Géry (1962, 1977) distinguished these species by head length, orbital diameter and interorbital width, and commented that (Boeseman, 1960: 93) "These differences, though apparently sufficient for specific discrimination, left some room for doubt, especially since the variability in the discriminative characters still remained to be determined", but decided to maintain $H$. guppyi as a separate species from $H$. taeniurus, although knowing that analysis was limited by the small number of specimens and mostly by not comparable sizes of the specimens available of each nominal species.

The syntypes of $H$. taeniurus are somewhat damaged with some caudal-fin rays broken and lacking several body scales. The dentition is preserved. The syntypes of $H$. guppyi are in good condition for all body measurements. We have analyzed the type series of $H$. taeniurus and T. Carvalho and R. Reis analyzed the types of $H$. guppyi when visiting the BMNH. We have compared the data of these species and did not find significant differences to distinguish the two species. Only the snout length in $H$. guppyi is slightly larger than the syntypes of $H$. taeniurus. This difference can be related to the observed differences in the standard length range between the type series of the two species (Table 7). New specimens from Trinidad were analyzed and no significant differences were found when compared with the type series of both species. Since there are no diagnostic features to support the recognition of two species, $H$. guppyi is herein considered a junior synonym of $H$. taeniurus.

Material examined. Syntypes. Hemibrycon taeniurus, ZMUC 962963, 2, 42.0-50.6 mm SL, ZMUC 966-968, 3, 33.0-45.0 mm SL, Island of Trinidad, Trinidad. Hemibrycon guppyi, BMNH 1906.6.23.13-17, 5, 46.3-73.4 mm SL, Trinidad. Non-type specimens. Trinidad and Tobago, Trinidad Island: AMNH 215239, 11 of 22 (2 c\&s), 57.4$81.8 \mathrm{~mm}$ SL, AMNH 215301, 5 of 10, 57.1-71.2 mm SL. CAS 70076, 3, 44.1-87.3 mm SL, West Indies, Guppy. INHS 40083, 2, 36.9-40.5 $\mathrm{mm} \mathrm{SL}$, río Quare, río Cunapo drainage, $1 \mathrm{~km}$ E Valencia on road to
Arima, St. Andrew County, ca. 10³9'N 61¹' 'W, 31 Jan 1997. MCNG 8199, 3 of 5 (1 c\&s), 53.4-66.1 mm SL, río Guanapo, 21 Jun 1983. ROM 61651, 1, $65.8 \mathrm{~mm}$ SL, from a few streams of freshwater, $10^{\circ} 25^{\prime} 00^{\prime \prime N} 61^{\circ} 08^{\prime} 00^{\prime \prime W}$. USNM 290408, 2 (x-ray), 49.4-53.8 mm SL, río Maracas, Jul-Aug 1987. USNM 290413, 2 (x-ray), 58.1-65.0 mm SL, río Matura, 23 Jul 1987.

\section{Hemibrycon tridens Eigenmann, 1922 Fig. 25}

Hemibrycon tridens Eigenmann, 1922: 152 (species described in key, distribution: extralimital, río Apurimac at Uruhuasi [Curuhuasi, upper río Ucayali drainage, Peru]). -Eigenmann, 1927: 402 (in key), 403-404 (pl. 96, fig. 3, original description, distribution: Uruhuasi, southeastern Peru; holotype 13723 IU).

Diagnosis. Hemibrycon tridens is readily distinguished from all congeners, except $H$. beni, by the number of branched anal-fin rays (17vs. 18-34, Fig. 2). Hemibrycon tridens differs from $H$. beni by the number of lateral line scales (39 vs. 4453 , Fig. 3), and by the number of scale rows above and below lateral line (6 and $5 v s$. 7-8 and 6-8, respectively). Among remaining Cis-Andean species of Hemibrycon, only $H$. helleri and $H$. mikrostiktos have lower branched anal-fin rays (19-23 and 18-21). From these species, H. tridens differs additionally by the number of lateral line scales (39 vs. 40-42 and 42-45, respectively).

Description. Morphometric data for $H$.tridens summarized in Table 5. Largest male $51.5 \mathrm{~mm}$ SL. Body compressed and elongate; greatest body depth anterior to dorsal-fin origin. Dorsal profile of head convex. Dorsal body profile convex from occipital bone to base of last dorsal-fin ray; straight from this point to adipose-fin origin. Ventral profile of head slightly convex. Ventral body profile convex from pectoral-fin origin to pelvic-fin origin, and straight to slightly convex to anal-fin origin. Body profile along anal-fin base posterodorsally slanted. Caudal peduncle elongate, nearly straight to slightly concave along dorsal and ventral margins.

Snout rounded from margin of upper lip to vertical through anterior nostrils. Head relatively small. Mouth sub-terminal, mouth slit nearly at horizontal through inferior margin of eye. Maxilla long and slightly curved, aligned at angle of approximately $45^{\circ}$ to longitudinal body axis, and its posterior tip extending below orbit, reaching nearly to vertical through center of eye.

Premaxilla with two tooth rows; outer row with 5 tricuspid teeth with central cusp slightly longer; inner row with 4 tri- to pentacuspids teeth, gradually decreasing in length from first to third teeth and last tooth smallest; central cusp twice or three times longer and broader than other cusps. Maxilla fully toothed with 12 tricuspid teeth, with central cusp longer. Three anteriormost dentary teeth larger, with 5 cusps, followed by medium sized tooth with 3 cusps, and 8 teeth with 1-3 cusps or conical; central cusp in all teeth two to three times longer and broader than other cusps. Cusp tips slightly curved posteriorly and lingually. 


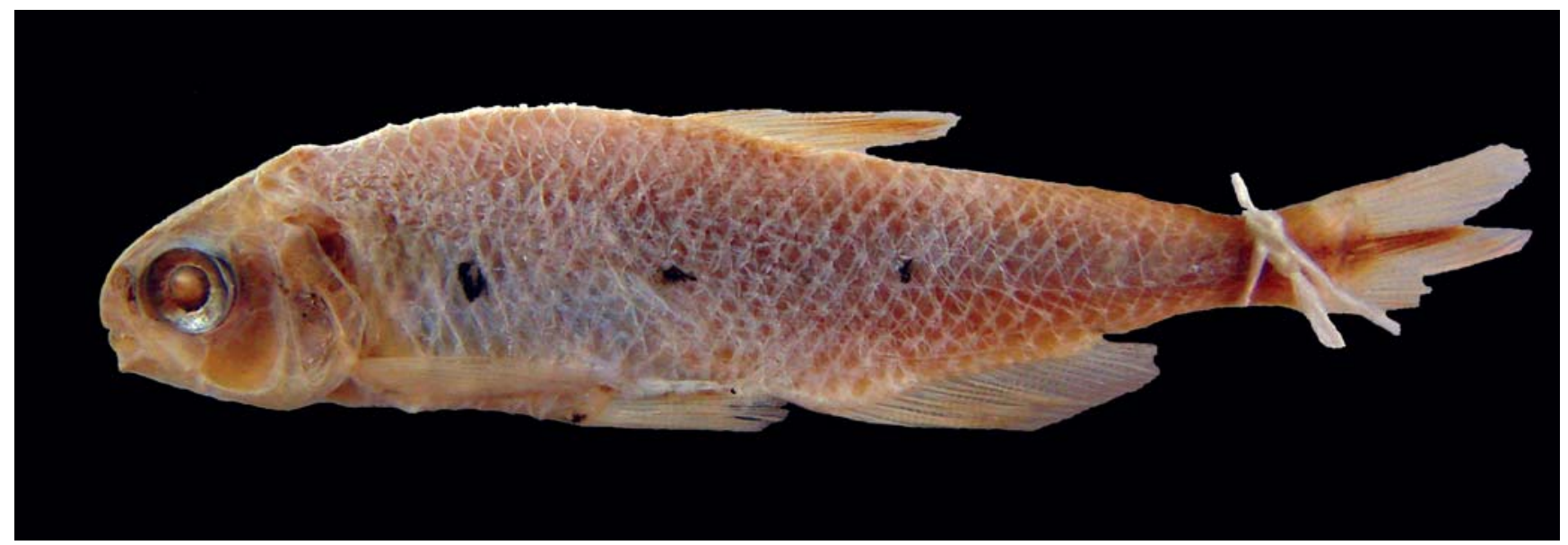

Fig. 25. Hemibrycon tridens, CAS 44358, holotype, $51.5 \mathrm{~mm} \mathrm{SL}$, male, upper río Ucayali basin, Peru. The black marks are preservation artifacts.

Dorsal-fin rays ii,8, first unbranched ray approximately onehalf length of second ray. Dorsal-fin origin located posterior to middle of SL and posterior to vertical through pelvic-fin origin. Profile of distal margin of dorsal fin slightly concave. Dorsal fin without bony hooks. Adipose-fin located at vertical through insertion posterior to last anal-fin ray. Anal-fin rays iii, 17 (Fig. 2). Anal-fin profile slightly nearly straight. Anal-fin origin approximately at vertical through insertion in the last dorsal fin rays. Anal-fin rays of male bearing one pair of small bony hooks along posterolateral border of each segment of lepidotrichia, along last unbranched ray and sixteenth branched rays. Hooks located along anteriormost branch and proximal $1 / 2$ to $2 / 3$ of each ray. Pectoral-fin rays i, 10. Pectoral-fin tip surpassing pelvicfin origin. Pectoral fin without bony hooks. Pelvic-fin rays i,6,i. Pelvic-fin tip nearly reaching anal-fin origin. Pelvic-fin origin located 4 predorsal scales anterior to vertical through dorsalfin origin. Pelvic fin of male bearing one small bony hook per segment of lepidotrichia along ventromedial border of second to seventh branched rays. Caudal fin forked with 19 principal rays without bony hooks; lobes similar in size. Caudal-fin base with a few scales. Dorsal procurrent rays 10 and ventral procurrent rays 10 (holotype $\mathrm{x}$-ray).

Scales cycloid, moderately large. Lateral line complete with 39 (Fig. 3). Scale rows between dorsal-fin origin and lateral line 6; scale rows between lateral line and pelvic-fin origin 5. Predorsal scales 14, arranged in regular series. Scales rows around caudal peduncle 14 .

Precaudal vertebrae 18; caudal vertebrae 22; total vertebrae 40. Supraneurals 5 (holotype $\mathrm{x}$-ray). Gill rakers on upper limb of outer gill arch 5, on lower limb 10.

Color in alcohol. Holotype badly preserved. Humeral and caudal peduncle spot not evident. Base of caudal fin and middle rays black pigmented. Distal half of dorsal fin with dark pigmentation, and caudal and anal fin with dark brown pigmentation diffuse. Pectoral and pelvic fins hyaline. Body yellowish. Left side of holotype has three black marks due to preservation artifacts (Fig. 25). Eigenmann (1927: 404) described the color pattern "A dark lateral band, caudal spot, and middle caudal rays dusky; distal parts of dorsal and anal and outer part of caudal lobes dusky; margin of lower caudal lobe dusky".

Sexual dimorphism. Male of Hemibrycon tridens is easily recognized by the presence of bony hooks on the anal- and pelvic-fin rays. No gill gland was observed on first gill arch.

Distribution. Hemibrycon tridens is known from río Apurimac, upper río Ucayali drainage, Curuhuasi, Peru (Fig. 4).

Remarks. Eigenmann (1922: 152) proposed Hemibrycon tridens based on one specimen, diagnosed in his key to Hemibrycon species. Only in 1927, Eigenmann presented a full description, and designated IUM 13723 (now CAS 44358) as the type specimen. The holotype is the only known specimen. The type locality provided by Eigenmann (1922) for $H$. tridens was "Rio Apurimac at Uruhuasi”. According to Hernán Ortega (pers. comm.), the correct type locality of $H$. tridens is the río Apurimac at Curuhuasi, upper río Ucayali drainage. He believed that Eigenmann erroneously wrote "Uruhuasi" instead of Curuhuasi.

Material examined. Holotype. CAS 44358, male (x-ray), 51.5 $\mathrm{mm}$ SL, Peru, 24 leagues from Cusco, Curuhuasi, province of Aymaraes, Department of Apurimac, F. Rosenberg.

\section{Hemibrycon divisorensis Bertaco, Malabarba, Hidalgo \& Ortega, 2007}

Hemibrycon divisorensis was recently described by Bertaco et al. (2007), from the upper río Ucayali drainage, Peru, and only an updated diagnosis is presented here.

Diagnosis. Hemibrycon divisorensis is distinguished from its congeners by the presence of a wide black asymmetrical spot covering the base of caudal-fin rays and extending along entire length of caudal-fin rays 9 to $12-13$ (except $H$. surinamensis), and by the presence of a black band in the lower half of the caudal peduncle from the region above the last anal-fin rays to the caudal-fin base. Furthermore, it is distinguished from its 
Cis-Andean congeners by the number of scale rows below lateral line (4-5 vs. 5-9), except $H$. mikrostiktos and $H$. surinamensis. It differs from $H$. mikrostiktos by the number of branched anal-fin rays (24-30 vs. 18-21), and from $H$. surinamensis by the number of scale sheath along anal-fin base (17-22 vs. 12-17), and by the number of cusps in the inner row of the premaxilla teeth (5-7vs. 4-5).

\section{Taxonomic status of Boehlkea orcesi (Böhlke, 1958), new combination}

Hemibrycon orcesi was described by Böhlke (1958) based on the holotype and three paratypes from río Macuma, Província de Santiago-Zamora, Ecuador. According to Böhlke, the species was proposed provisionally in Hemibrycon because the lobes of the caudal-fin were scaled and disagree with Eigenmann's definition for Hemibrycon. In 1962, Géry also suspected that $H$. orcesi could belong to a new genus related to Hemibrycon, but clearly different from it.

The type specimens of $H$. orcesi possess the caudal fin scaled or with scale marks to proximal half of lobes, a character not found in Hemibrycon species. In all type specimens some body scales are lacking and are not in good conditions of preservation, thus it is not possible to know if the lateral line is incomplete or complete. Böhlke (1958: 27) when describing a lateral line complete to $H$. orcesi commented that "though all lateral line counts were interrupted by areas where scales were missing". Also, Böhlke commented "although the caudal scalation of all the present specimens is damaged to some extent, some specimens (most notably the holotype) still possess scales which extend more than half-way out on the caudal lobes".

Differently of the genera belonging to the Stevardiinae sensu Mirande $(2009,2010)$, the species of Hemibrycon and Boehlkea share a large number of teeth in the maxilla, as observed in the types of $H$. orcesi (13-14 uni- to pentacuspid teeth) and in the only species of Boehlkea, B. fredcochui Géry (14-15 uni- to tricuspid teeth). Boehlkea differs from Hemibrycon by the presence of scales in the caudal fin lobes, lateral line interrupted, and smaller total number of vertebrae (36 vs. 38-43). Besides lobes of caudal fin scaled, H. orcesi possess other features uncommon for Hemibrycon species, as the short lateral line (34 to $35 v s$. 39-58 scales); smaller number of vertebrae ( 36 to 37 total vertebrae); and color pattern of dorsal, anal and ventral fins, densely pigmented. Recently, this species was redescribed in Hemibrycon from ríos Macuma and Pastaza, in Ecuador by Román-Valencia et al. (2007), but according with characters commented here its is considered as belonging to Boehlkea.

We have analyzed the holotype and one paratype of Boehlkea fredcochui, and the caudal-fin presented small scales to half of upper and lower lobes, lateral line interrupted with 14 perforated scales plus 23 remaining scales (last scales perforated or unperforated), and 37 scales in the longitudinal series. Further, $B$. orcesi differs from $B$. fredcochui by number of the branched anal-fin rays (17-18 vs. 24-25), pelvic-fin rays ( $8 v s .7)$, lateral line scales (34-35 vs. 37), and scale rows above of the lateral line (6-7 vs. 5), color pattern, and by some body measurements.

\section{Discussion}

Relationships of Hemibrycon species lie within Stevardiinae (sensu Mirande) as first hypothesized by Malabarba \& Weitzman (2003) in their Clade A, and further supported by Calcagnotto et al. (2005), Mirande (2009, 2010), and Javonillo et al. (2010). The common sharing of the apomorphic number of four teeth in the inner series of the premaxilla and ii, 8 dorsal fin rays allows to recognize Hemibrycon species and to diagnose them from most characids, except for other genera of the Stevardiinae.

Although relationships of Hemibrycon are partially cleared, we failed to find exclusive synapomorphies in the external morphology and osteology in defining the genus, and this seems to be related to the conservative or primitive morphology of its representatives. Malabarba \& Weitzman (2003) considered Hemibrycon and Boehlkea as apparently the most basal genera in Clade A, by lacking specializations related to insemination, development of caudal and/or anal glands, or jaw and teeth modifications related to the ventral mouth, observed in the species of the remaining genera of that clade. This "primitiveness" or conservative morphology of Hemibrycon was further supported by Mirande (2009) in an overall phylogenetic analysis of 160 species of characid fishes, including Hemibrycon dariensis and H. surinamensis, and based on 360 morphological characters, that recovered Hemibrycon as basal sister group of all remaining Stevardiinae genera [Hemibrycon (Cyanocharax ((Knodus + Bryconamericus species) (((Attonitus Vari \& Ortega, Aulixidens Böhlke) (Bryconamericus species (Acrobrycon Eigenmann \& Pearson, ((Mimagoniates, Pseudocorynopoma), Diapoma)))) (Bryconamericus species (Nantis Mirande, Aguilera \& Azpelicueta, (Odontostoechus, (Piabina, Creagrutus)))))))]. Although recovering the two Hemibrycon species as monophyletic, the synapomorphies found by Mirande (2009) for that clade were also not exclusive: heterogeneity of dentary teeth, with anterior teeth larger, with five or more cusps, and posterior teeth conical; the relative length of the palatine approximately half length of ectopterygoid, or less; the palatine foramen present, very conspicuous; and the presence of one row of gill rakers on second ceratobranchial.

Among characters proposed by Eigenmann (1917, 1927) to diagnose Hemibrycon, most are simplesiomorphies shared by most Stevardiinae and little informative in delimiting the species that belong to the genus as such is the case for the premaxillary with two series of teeth, inner series with four teeth, infraorbital 2 in contact with the lower limb of the preopercle, adipose fin present, anal fin moderate or long, and gill rakers simple. Only the maxilla with teeth along its greater part or along its entire edge and the caudal fin naked seems to be useful in further defining Hemibrycon.

Although number of maxillary teeth is highly variable among several characid lineages, the largely toothed maxilla is uncommon among stevardiines. Number of maxillary teeth varies from 6 to 20 in Hemibrycon species, leaving the 
edentulous portion of the maxilla smaller than toothed portion. Among stevardiine taxa larger counts are found in Cyanocharax alburnus (2-8 maxillary teeth), Mimagoniates rheocharis (3-8), Bryconamericus peruanus (3-7), B. cristiani (3-9), and B. yokiae (5-8), but only the anterior portion of maxillary is toothed in those species, leaving the edentulous portion of the maxilla clearly larger than toothed portion. Only Boehlkea shares with Hemibrycon the presence of edentulous portion of maxilla smaller than toothed portion, associated with the largest number of teeth in the maxilla. Hemibrycon differs from Boehlkea, however, in having the lobes of caudal-fin naked (vs. scaled), lateral line complete (vs. incomplete or interrupted), and larger total number of vertebrae (38-43 vs. 36).

As now defined, Hemibrycon is delimited by the possession of the synapomorphies of Stevardiinae, combined with the absence of the synapomorphies diagnostic of other internal clades, as well as by the possession of an elevated number of maxillary teeth (6 to 20), leaving the edentulous portion of the maxilla smaller than toothed portion.

Due to the lack of recognizable exclusive synapomorphies to the genus in the external morphology and osteology, additional characters must be included in future studies. Recently, new and inseminating genera were proposed and included in the Stevardiinae as Lophiobrycon Castro, Ribeiro, Benine \& Melo (2003), Bryconadenos Weitzman, Menezes, Evers \& Burns (2005), and Phallobrycon Menezes, Ferreira \& Neto-Ferreira (2009). Among these, only the two last genera possess intumescent glandular tissue formed by club cells on the anterior portion of anal fin (Menezes et al., 2009), and the former have a caudal-fin organ (Glandulocaudini); all these characters are absent in Hemibrycon. The actual number of valid species of Hemibrycon still remains questionable or doubtful. Twelve species are recognized herein to the east of the Andean Cordilleras, but a revision of the species of Hemibrycon found to the west of the Andean Cordilleras is urging.

\section{Comments about the distribution of the Cis-Andean species of Hemibrycon}

According to Géry (1962) Hemibrycon species have a peculiar distribution in the Amazon basin, and are confined to the periphery of the basin, inhabiting the upper portions of their tributaries. They are found usually in mountain streams with clear and fast water, and do not live in the slow running rivers of the lowlands (Géry, 1962), except H. surinamensis. Hemibrycon surinamensis was originally described to Atlantic coastal rivers of Suriname and posteriorly found in coastal rivers of French Guyana (Géry et al., 1991), and according we results it also occurs in the lower rios Tapajós, Tocantins and Xingu basins, Brazil.

Among Characidae genera (or Clade A genera), the peripheral distribution pattern is similar and largely congruent with the distribution given to the species of Creagrutus Günther by Harold \& Vari (1994), and Vari \& Harold (2001). All species of Hemibrycon from the Trans-Andean basins are different species from those in rivers east of the Andean Cordilleras, a situation found in other groups of fishes taxonomically revised, e.g., Creagrutus.

\section{Key to the Cis-Andean species of Hemibrycon}

1. Humeral spot extending over 7 to 9 horizontal series of scales .............................................. 2

1 '. Humeral spot extending over 2 to 6 horizontal series of scales.................................................. 3

2.19 to 23 branched anal-fin rays; 6 to 12 scales sheath along anal-fin base; 16 to 18 predorsal scales.............. H. helleri (upper río Ucayali drainage, Peru)

2'. 25 to 30 branched anal-fin rays; 13 to 28 scales sheath along anal-fin base; 12 to 16 predorsal scales......H.jelskii (upper portions of ríos Marañon, Ucayali, MadeiraMamoré drainages in Bolivia, Brazil and Peru)

3. Small humeral spot and extending over 2 to 3 horizontal series of scales; total number of pelvic fin rays $7 ; 3$ to 4 scale rows below of the lateral line........H. mikrostiktos (upper río Ucayali drainage, Peru)

3 '. Humeral spot extending over 4 to 6 horizontal series of scales; total number of pelvic fin rays $8 ; 4$ to 9 scale rows below of the lateral line................................... 4

4. Presence of a wide black asymmetrical spot covering base of caudal-fin rays and extending along entire length of caudal-fin rays 9 to $12-13$.

4'. Absence of a wide black asymmetrical spot covering base of caudal-fin rays.......................................6

5. Presence of a black band in the lower half of the caudal peduncle from the region above the last anal-fin rays to the caudal-fin base; scale sheath along anal-fin base 17 to 22; total number of gill rakers 20 to 22 . H. divisorensis (upper río Ucayali drainage, Peru)

5'. Absence of a black band in the lower half of the caudal peduncle from the region above the last anal-fin rays to the caudal-fin base; scale sheath along anal-fin base 12-17; total number of gill rakers 19 to

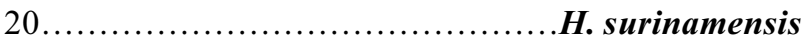
(coastal basins of French Guiana and Suriname, and lower rios Tocantins, Tapajós and Xingu basins, Brazil)

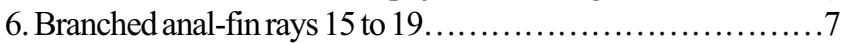

6 '. Branched anal-fin rays 22 to $31 \ldots \ldots \ldots \ldots \ldots \ldots \ldots \ldots \ldots$

7. Lateral line scales $39 ; 6$ scale rows above of the lateral line; 14 scales around caudal-peduncle. H. tridens (upper río Ucayali drainage, Peru)

7'. Lateral line scales 44 to $53 ; 7$ to 8 scale rows above of the lateral line; 16 to 18 scales around caudal-peduncle...........H. beni (río Beni drainage, Bolivia)

8. Gill rakers 16-18; scales sheath along anal-fin base 610. H. inambari (upper río Madre de Dios drainage, Peru)

8'. Gill rakers 19-21; scales sheath along anal-fin base 10-

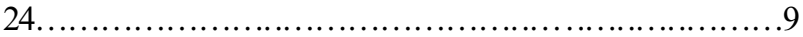

9. Lateral line scales 40 to 42 (usually 41 ); 7 to 8 scale rows above of the lateral line; head and body slim

....................................................... 10

9'. Lateral line scales 42 to 48 (usually $44-45$ ); 8 to 10 scale rows above of the lateral line; head and body robust 
10. Second tooth of premaxillary inner row teeth heptacuspidate; humeral spot extending over 5 to 6 (usually 5) horizontal series of scales. H. metae (río Orinoco drainage, Venezuela and Colombia)

10 '. Second tooth of premaxillary inner row teeth pentacuspidate; humeral spot extending over 4 to 5 (usually 4) horizontal series of scales. . H. taeniurus (rivers of Island Trinidad, Trinidad and Tobago)

11. Caudal peduncle scales 18 to 20 ; head length $22.0-26.0 \%$ of SL; upper jaw length 45.2-52.6\% of HL...........H. huambonicus (río Huallaga drainage, Peru)

11'. Caudal peduncle scales 16 ; head length $20.9-22.9 \%$ of SL; upper jaw length $43.7-45.6 \%$ of HL......... H. polyodon (río Pastaza drainage, Ecuador)

Comparative material. In addition to the comparative material listed in Bertaco et al. (2007), the following specimens were analyzed: Boehlkea fredcochui, ANSP 111675, holotype, upper Amazon, Paramount Aquarium via Tropicarium Frankfurt am Main; ANSP 111668, paratype, upper Amazon from surroundings of Leticia, Colombia, Paramount Aquarium import via Herbert R. Axelrod. Bryconamericus dentatus, FMNH 56253, holotype, Piedra de Moler, upper rio Cauca basin, Colombia; CAS 39543, 4 of 5 paratypes, up river from Cartago, río Paila into río Cauca, Valle del Cauca, Colombia. Hemibrycon boquiae, FMNH 56259, holotype (x-ray), FMNH 56260, 10 (3 x-ray), upper rio Cauca basin, Boquia, Colombia; IAvH-P 7762, 29, río San Rafael, upper rio Cauca basin, Risaralda, Colombia. Hemibrycon colombianus, IAvH-P 3130, 26, río Moniquira and río Suarez, Santander, Colombia. Hemibrycon dariensis, ANSP 151226, 12, rio Tuira basin, Darién, Panama. Hemibrycon orcesi, USNM 164064, holotype, USNM 175128, paratype, río Macuma, northern tributary of upper río Morona, upper Amazon, Santiago-Zamora, Ecuador.

\section{Acknowledgements}

We are grateful to Scott Schaefer and Barbara Brown (AMNH), John Lundberg and Mark Sabaj (ANSP), David Catania (CAS), Mary Anne Rogers (FMNH), Andrew Bently (KU), Guy Duhamel and Patrice Pruvost (MNHN), Hernán Ortega and Max Hidalgo (MUSM), Paulo Buckup and Marcelo Britto (MNRJ), Osvaldo Oyakawa (MZUSP), Helmut Wellendorf and Ernst Mikschi (NMW), Rick Winterbotton and Erling Holm (ROM), H. Zetzsche and F. Krupp (SMF), Stanley Weitzman, Richard Vari and Sandra Raredon (USNM) for selection and loan of specimens; to Roberto Reis (MCP) and Tiago Carvalho (UL at Lafayette) by the examination of the types of H. polyodon and H. guppyi at BMNH; to Paulo Petry and Fernando Carvalho by the examination of $H$. helleri at MCZ; to Monica Rodrigues (LIRP) by the examination of holotype of $H$. dentatus; to Javier Maldonado (IAvH) by assistance in the Instituto Alexander von Humboldt; to Fernando Carvalho (UFRGS) by suggestions in the manuscript; to the Centro de Microscopia e Microanálises CEMM, PUCRS for the SEM preparations. VAB is grateful by the Fellowships offered by the Academy of Natural Sciences, California Academy of Sciences, Field Museum of Natural History, Muséum d'historie naturelle, Geneva, National
Museum of Natural History, Smithsonian Institution, and is financed by a postdoctoral fellowship from $\mathrm{CNPq}$ (Proc. 150042/2009-4). The Coordenação de Aperfeiçoamento de Pessoal de Nível Superior (CAPES) provided financial support to VAB during his Doctoral thesis. This project is supported by CNPq (Proc. 479412/2008-1) and FAPERGS (Proc. 0903014).

\section{Literature Cited}

Alves, C. B. M. \& P. S. Pompeu. 2001. Peixe do rio das Velhas: passado e presente. Belo Horizonte, SEGRAC, 194p.

Bertaco, V. A., L. R. Malabarba, M. Hidalgo \& H. Ortega. 2007. A new species of Hemibrycon (Teleostei: Characiformes: Characidae) from the río Ucayali drainage, Sierra del Divisor, Peru. Neotropical Ichthyology, 5(3): 251-257.

Boeseman, M. 1960. The fresh-water fishes of the Island of Trinidad. Studies on the fauna of Curaçao and other Caribbean Islands, (48): 73-153.

Böhlke, J. 1953. A catalogue of the type specimens of recent fishes in the Natural History Museum of Stanford University. Stanford Ichthyology Bulletin, 5: 1-168.

Böhlke, J. E. 1958. Studies on fishes on the family Characidae. No. 14. A report on several extensive recent collections from Ecuador. Proceedings of the Academy of Natural Sciences of Philadelphia, 110: 1-121.

Burns, J. R. \& S. H. Weitzman. 1996. Novel gill-derived gland in the male swordtail characin, Corynopoma riisei (Teleostei: Characidae: Glandulocaudinae). Copeia, 1996(3): 627-633.

Calcagnotto, D., S. A. Schaefer \& R. DeSalle. 2005. Relationships among characiform fishes inferred from analysis of nuclear and mitochondrial gene sequences. Molecular Phylogenetic and Evolution, 36(1): 135-153.

Castro, R. M. C., A. C. Ribeiro, R. C. Benine \& A. L. A. Melo. 2003. Lophiobrycon weitzmani, a new genus and species of glandulocaudine fish (Characiformes: Characidae) from the rio Grande drainage, upper rio Paraná system, southeastern Brazil. Neotropical Ichthyology, 1(1): 11-19.

Eigenmann, C. H. \& W. R. Allen. 1942. Fishes of Western South America. I. The Intercordilleran and Amazonian Lowlands of Peru. II. The high pampas of Peru, Bolivia and Northern Chile. With a revision of the Peruvian Gymnotidae, and of the genus Orestias. University of Kentucky, Lexington, 494p.

Eigenmann, C. H. 1909. The fresh-water fishes of Patagonia and an examination of the Archiplata-Archhelenis theory. Pp. 225-374. In: Reports of the Princeton University expeditions to Patagonia, 1896-1899. Princeton University \& Stuttgart, 3(3): 211-374.

Eigenmann, C. H. 1910. Catalogue of the freshwater fishes of tropical and south temperate America. Pp. 375-511. In: Reports of the Princeton University expeditions to Patagonia, 1896-1899. Princeton University \& Stuttgart, 3(4): 375-511.

Eigenmann, C. H. 1917. The American Characidae. Part 1. Memoirs of the Museum of Comparative Zoology, 43(1): 1-102.

Eigenmann, C. H. 1922. The fishes of western South America, Part I. The fresh-water fishes of northwestern South America, including Colombia, Panama, and the Pacific slopes of Ecuador and Peru, together with an appendix upon the fishes of the Rio Meta in Colombia. Memoirs of the Carnegie Museum, 9(1): 1-346.

Eigenmann, C. H. 1927. The American Characidae. Part 4. Memoirs of the Museum of Comparative Zoology, 43(4): 311-428.

Eschmeyer, W. N. (Ed.). 1998. Catalog of fishes. Introductory Materials. Species of Fishes, A-L and M-Z. San Francisco: California Academy of Sciences. Volume 1 (958p.) and Volume 2 (959-1820p.). 
Eschmeyer, W. N. (Ed.). 2010. Catalog of Fishes. Electronic version - 12 July 2010. California Academy of Sciences. Avalaible at: http://research.calacademy.org/ichthyology/catalog/ fishcatmain.asp. Accessed July 25, 2010.

Fink, W. L. \& S. H. Weitzman. 1974. The so-called cheirodontin fishes of Central America with descriptions of two new species (Pisces: Characidae). Smithsonian Contributions to Zoology, 172: 1-46.

Fowler, H. W. 1943. Two new characins from eastern Ecuador. Notulae Naturae, Philadelphia, (119): 1-5.

Géry, J. R. 1962. Notes on the ichthyology of Surinam and other Guianas. 10. The distribution pattern of the genus Hemibrycon, with a description of a new species from Surinam and an incursion into ecotaxonomy. Bulletin of Aquatic Biology, 3(28): 65-80.

Géry, J. R. 1977. Characoids of the world. T. F. H. Publications, Neptune City, 672p.

Géry, J. R., P. Planquette \& P. -Y. Le Bail. 1991. Faune characoïde (poissons ostariophysaires) de l'Oyapock, l'Approuague et la rivière de Kaw (Guyane Française). Cybium, 15 (1, suppl.): 1-69.

Gill, T. N. 1858. Synopsis of the fresh water fishes of the western portion of the island of Trinidad, W. I. Annals of Lyceum of Natural History of New York, 6: 363-430.

Günther, A. 1864. Catalogue of the fishes in the British Museum. Catalogue of the Physostomi, containing the families Siluridae, Characinidae, Haplochitonidae, Sternoptychidae, Scopelidae, Stomiatidae in the collection of the British Museum. Catalogue Fishes, 5: 1-455.

Harold, A. \& R. P. Vari. 1994. Systematics of the Trans-Andean Species of Creagrutus (Ostariophysi: Characiformes: Characidae). Smithsonian Contributions to Zoology, (551): 1-31.

Ibarra, M. \& D. J. Stewart. 1987. Catalogue of type specimens of recent fishes in Field Museum of Natural History. Fieldiana Zoology, New Series (35): 1-112.

Javonillo, R., L. R. Malabarba, S. H. Weitzman \& J. R. Burns. 2010. Relationships among major lineages of characid fishes (Teleostei: Ostariophysi: Characiformes), based on molecular sequence data. Molecular Phylogenetics and Evolution, 54(2010): 498-511.

Lima, F. C. T, L. R. Malabarba, P. A. Buckup, J. F. Pezzi da Silva, R. P. Vari, A. Harold, R. Benine, O. T. Oyakawa, C. S. Pavanelli, N. A. Menezes, C. A. S. Lucena, M. C. S. L. Malabarba, Z. M. S. Lucena, R. E. Reis, F. Langeani, L. Casatti, V. A. Bertaco, C. Moreira \& P. H. F. Lucinda. 2003. Genera incertae sedis in Characidae. Pp. 134-141. In: Reis, R. E., S. O. Kullander \& C. J. Ferraris (Eds.). Check List of the Freshwater Fishes of South and Central America. Porto Alegre, Edipucrs, 729p.

Lütken, C. F. 1875. Ichthyographiske Bidrage. III. Nogle nye eller mindre fuldstaendigt kjendte, mellem- eller sydamerikanske Karpelax (Characiner). Videnskabelige Meddelelsel fra den naturhistoriske Forening i Kjöbenhavn, 1874(12-16): 220-240.

Malabarba, L. R. \& S. H. Weitzman. 2003. Description of new genus with six new species from southern Brazil, Uruguay and Argentina, with a discussion of a putative characid clade (Teleostei: Characiformes: Characidae). Comunicações do Museu de Ciências e Tecnologia da PUCRS, Série Zoologia, 16(1): 67-151.

Menezes, N. A., K. M. Ferreira \& A. L. Neto-Ferreira. 2009. A new genus and species of inseminating characid fish from the rio Xingu basin (Characiformes: Characidae). Zootaxa, 2167: 47-58.

Mirande, J. M. 2009. Weighted parsimony phylogeny of the family Characidae (Teleostei: Characiformes). Cladistics, 25(6): 574613.

Mirande, J. M. 2010. Phylogeny of the family Characidae (Teleostei: Characiformes): from characters to taxonomy. Neotropical Ichthyology, 8(3): 385-568.
Myers, G. S. 1930. Fishes from the upper Rio Meta Basin, Colombia. Proceedings of the Biological Society of Washington, 43: 65-71. Nielsen, J. G. 1974. Fish types in the Zoological Museum of Copenhagen, $115 \mathrm{p}$.

Pearson, N. E. 1924. The fishes of the eastern slope of the Andes. I. The fishes of the Rio Beni basin, Bolivia, collected by the Mulford expedition. Indiana University Studies, 11(64): 1-83, pls. 1-12.

Planquette, P., P. Keith \& P. -Y. Le Bail. 1996. Atlas des poissons d'eau douce de Guyane (Tome 1). Muséum National d'Historie Naturelle, Ministère de l'Environnement. Atlas Poissons Guyane, 431p.

Regan, C. T. 1906. On the fresh water fishes of the Island of Trinidad, based on the collections, notes, and sketches made by Mr. Lechmere Guppy, Junr. Proceedings of the Zoological Society of London, (1): 378-393.

Reis, R. E., S. O. Kullander \& C. J. Ferraris (Eds.). 2003. Check List of the Freswater Fishes of South and Central America. Porto Alegre, Edipucrs, 729p.

Román-Valencia, C., R. I. Ruiz-C. \& R. Barriga. 2006. Una nueva especie de pez del género Hemibrycon (Characiformes: Characidae). Revista de Biología Tropical, 54(1): 209-217.

Román-Valencia, C., R. I. Ruiz-C. \& R. Barriga. 2007. Redescripción de Hemibrycon orcesi Böhlke, 1958 y H. polyodon (Gunther, 1864) (Teleostei, Characidae), incluye clave para las especies de Hemibrycon en Ecuador. Animal Biodiversity and Conservation, 30(2): 179-188.

Román-Valencia, C. \& D. C. Arcila-Mesa. 2009. Two new species of Hemibrycon (Characiformes, Characidae) from the Magdalena River, Colombia. Animal Biodiversity and Conservation, 32(2): 77-87.

Schultz, L. P. 1944. The fishes of the family Characinidae from Venezuela, with descriptions of seventeen new forms. Proceedings of the United States National Museum, 95(3181): 235-367.

Steindachner, F. 1877. Ichthyologische Beiträge. IV. Anzeiger der Akademie der Wissenschften, Wien, 72(1): 551-616.

Steindachner, F. 1882. Beiträge zur Kenntniss der Flussfische Südamerikas. IV. Denkschriften der MathematischNaturwissenschaftlichen Classe der Kaiserlichen Anzeiger der Akademie der Wissenschften, Wien, 46: 1-44.

Stephens, L. \& M. A. Traylor, Jr. 1983. Ornithological Gazetteer of Peru. Cambridge, Massachusetts: Museum of Comparative Zoology. Harvard University, 271p.

Taczanowski, W. 1884. Ornithologie du Pérou. Volume 2. Rennes: Typographie Oberthur, 566p.

Taylor, W. R. \& G. C. van Dyke. 1985. Revised procedures for staining and clearing small fishes and other vertebrates for bone and cartilage study. Cybium, 9(2): 107-119.

Vari, R. P. \& A. S. Harold. 2001. Phylogenetic study of the neotropical fish genera Creagrutus Günther and Piabina Reinhardt (Teleostei: Ostariophysi: Characiformes), with a revision of the Cis-Andean species. Smithsonian Contributions to Zoology, 613: 1-239.

Vari, R. P. \& J. C. Howe. 1991. Catalogue of type specimens of recent fishes in the National Museum of Natural History, Smithsonian Institution, 1: Characiformes (Teleostei: Ostariophysi). Smithsonian Contribution to Zoology, 517: 1-52.

Weitzman, S. H. \& L. R. Malabarba. 1999. Systematics of Spintherobolus (Teleostei: Characidae: Cheirodontinae) from eastern Brazil. Ichthyological Exploration of Freshwaters, 10(1): 1-43.

Weitzman, S. H., N. A. Menezes, H. G. Evers \& J. R. Burns. 2005. Putative relationships among inseminating and externally fertilizing characids, with a description of a new genus and species of Brazilian inseminating fish bearing an anal-fin gland in males (Characiformes: Characidae). Neotropical Ichthyology, 3(3): 329-360.

Accepted September 29, 2010 Published December 16, 2010 